Paternotte, E., Dulmen, S. van, Lee, N. van der, Scherpbier, A.J.J.A., Scheele, F. Factors influepæing intercultural doctor-patient communication: a realist review. Patient Education and Counseling: 2015, 98(4), 420-445

\begin{tabular}{|l|l|}
\hline $\begin{array}{l}\text { Postprint } \\
\text { Version }\end{array}$ & 1.0 \\
\hline Journal website & http://www.pec-journal.com/article/S0738-3991(14)00491-1/abstract \\
\hline Pubmed link & http://www.ncbi.nlm.nih.gov/pubmed/25535014 \\
\hline DOI & $10.1016 /$ j.pec.2014.11.018 \\
\hline
\end{tabular}

\title{
Factors influencing intercultural doctor-patient communication: A realist review
}

\author{
EMma PATERNOTTE ${ }^{\text {A, }}$, SANDRA VAN DULMEN ${ }^{\text {B, C, D, }}$, NADINE VAN DER LEE ${ }^{\text {A, }}$, AlbeRT J.J.A. \\ SCHERPBIER ${ }^{\mathrm{E}}$, FEDDE SCHEELE \\ a Department of Healthcare Education, Sint Lucas Andreas hospital, Amsterdam, The Netherlands \\ b NIVEL (Netherlands Institute for Health Services Research), Utrecht, The Netherlands \\ ${ }^{c}$ Department of Primary and Community Care, Radboud University Medical Centre, Nijmegen, The \\ Netherlands \\ ${ }^{d}$ Faculty of Health Sciences, Buskerud and Vestfold University College, Drammen, Norway \\ e Institute for Medical Education, Faculty of Health, Medicine and Life Sciences, Maastricht University, \\ Maastricht, The Netherlands \\ ${ }^{\mathrm{f}}$ Medical School of Sciences, Vu University Medical Center, Amsterdam, The Netherlands
}

\begin{abstract}
Objective: Due to migration, doctors see patients from different ethnic backgrounds. This causes challenges for the communication. To develop training programs for doctors in intercultural communication (ICC), it is important to know which barriers and facilitators determine the quality of ICC. This study aimed to provide an overview of the literature and to explore how ICC works.

Methods: A systematic search was performed to find literature published before October 2012. The search terms used were cultural, communication, healthcare worker. A realist synthesis allowed us to use an explanatory focus to understand the interplay of communication.

Results: In total, 145 articles met the inclusion criteria. We found ICC challenges due to language, cultural and social differences, and doctors' assumptions. The mechanisms were described as factors influencing the process of ICC and divided into objectives, core skills and specific skills. The results were synthesized in a framework for the development of training.

Conclusion: The quality of ICC is influenced by the context and by the mechanisms. These mechanisms translate into practical points for training, which seem to have similarities with patient-centered communication.

Practice implications: Training for improving ICC can be developed as an extension of the existing training for patient-centered communication.
\end{abstract}




\section{Abbreviations}

- Dr, doctor (plural—drs);

- Pt, patient (plural-pts);

- GP, general practitioner;

- AA, African American;

- SA, South-Asian;

- DM, decision making;

- US, United States;

- UK, United Kingdom

\section{INTRODUCTION}

Due to increasing worldwide migration since the 1960, healthcare in the modern Western world is confronted with the consequences of a multi-ethnic society [1]. One of the main areas where these consequences are apparent is in the interaction between doctors and patients. As research on communication in healthcare has shown, there is ample evidence that communication affects numerous outcomes, such as patient satisfaction and adherence, and, consequently, health outcomes [2] and [3]. One of the challenging areas of healthcare communication is communication with culturally diverse patients [4]. Intercultural doctor-patient contacts are potential sources of misunderstanding and low quality communication, which may reduce the quality of care [5].

Causes for misunderstanding and difficulties in intercultural communication (ICC) are sought in differences in perspectives, values and beliefs about illness between doctors and patients with different ethnic backgrounds [6], [7], [8] and [9]. Illness is culturally determined in the sense that how we perceive, experience and cope with disease is based upon our explanations of illness [7]. Hence, difficulties in intercultural doctor-patient communication could be explained by differences in culture rather than by a supposed inferiority of specific cultures [8]. Another possible influence on the quality of patient communication is that many doctors feel incompetent to communicate and relate to patients from different ethnic backgrounds due to a lack of adequate skills, language barriers or knowledge of communication with these patients [10] and [11]. For example, doctors behave less effectively when interacting with ethnic minority patients compared to ethnic majority patients [5] and [12]. Also, ethnic minority patients themselves are less verbally expressive and seem to be less assertive during the medical encounter than ethnic majority patients [12].

In recent years, medical education has paid more attention to ICC, or to cultural competence on a broader scale (see Table 1 for terminology). Although the necessity of training in ICC has been increasingly recognized [13], many countries with a multi-ethnic patient population have not structurally implemented training in this area in their medical curricula [14] and [15], even though there is a flourishing debate about appropriate training of health professionals to respond to ethnic diversity [16] and [17]. Next to the difficulties of implementing ICC in medical curricula, assessment of ICC remains challenging [18], and there is a risk that ICC and cultural competence training reinforce stereotyping [19]. The challenge, therefore, is to achieve a balance between theory and practice. Developing an appreciation of theoretical concepts of ICC is desirable for 'generic learning'. However, such learning would fail without emphasizing its relevance to practice [16]. 
Paternotte, E., Dulmen, S. van, Lee, N. van der, Scherpbier, A.J.J.A., Scheele, F. Factors influepring intercultural doctor-patient communication: a realist review. Patient Education and Counseling: 2015, 98(4), 420-445

\section{[TABLE 1]}

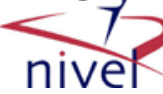

The field of ICC in healthcare has been studied extensively. For example, Schouten et al. performed a systematic review in this field to gain more insight into the effects of ethnic background on the medical communication process [12]. Although their research was substantial, it was limited by including observational studies only. The authors concluded that there are differences in the communication with ethnic minority patients compared to ethnic majority patients, and they advised to focus further research on explanatory factors to advance knowledge about the origins of and solutions for problems in ICC [12].

Several studies recommended an exploratory review to reveal what factors influence the outcome of ICC [20], but as far as we know, such a review is still lacking. A systematic description of the influencing factors in ICC may inform the development and implementation of training and education for doctors, which could provide opportunities to facilitate communication of better quality [1] and [21]. Also, such research could give insight into the link between patient-centered communication and ICC, which was mentioned in several papers [13] and [17].

The present paper provides an overview of the literature on the perceptions and experiences of doctors and patients related to communication in an intercultural setting. Although ICC can include many contexts, we focused on the largest and perhaps most challenging group of intercultural encounters, i.e. those between doctors of the ethnic majority and their patients of the ethnic minority (see Table 1 for the used definition of ICC). Our research was guided by the following questions: Which factors influence the communication process between doctors and patients of different ethnic backgrounds? How do these factors influence the communication?

To apply the intended exploratory focus, we performed a realist synthesis, which could help us to gain insight into the complexity of communication between doctors and patients [22]. We tried to formulate a framework for medical education, which could be used for the development of ICC training for doctors. Our main focus was not on the misunderstandings, but on the broader concept of intercultural communication.

\section{METHODS}

We conducted a systematic review of the literature using the realist synthesis method guided by the RAMESES guideline, a realist review guideline [22]. A realist review is a strategy for synthesizing research that has an explanatory rather than a judgmental focus. It can include qualitative as well as quantitative studies, which enables us to focus on the content, i.e. meaningful and useful results, of the articles. The adjective realist refers to the philosophy of science called Realism, which is situated between positivism, i.e. the conviction that there is a real world and that we can apprehend this world directly through observation, and constructivism, i.e. the conviction that reality is a social construction and that we cannot know what the true nature of reality is [29] and [30].

A realist synthesis emphasizes how causal mechanisms are shaped and constrained by social context. The extracted data are described and explored using the model of context (C), mechanism (M) and outcome (O). For example, to evaluate the ICC process (O), a realist synthesis would examine its underlying mechanisms (e.g. the way a doctor behaves in a 
Paternotte, E., Dulmen, S. van, Lee, N. van der, Scherpbier, A.J.J.A., Scheele, F. Factors influepæing intercultural doctor-patient communication: a realist review. Patient Education and Counseling: 2015, 98(4), 420-445

conversation), and its contiguous contexts (e.g. a language barrier between the doctor and the patient) [22] and [30].

\subsection{Data sources and searches}

Literature searches were performed by an experienced information specialist, who searched MEDLINE, EMBASE, PsycInfo, Cinahl, Cochrane and Education Resources Information Center (ERIC) for relevant papers using Reference Manager 12. All studies published before October 2012 were included. No language restrictions were applied, and papers were translated if necessary. However, articles without English abstract were excluded, as were letters, reviews, comments, case reports, books, and editorials.

Databases were searched using keywords for both free text (tiab) and Medical Subject Heading (MeSH) terms. A combination of the following keywords and synonyms were used: communication AND cultural AND ethnic AND healthcare worker. The broad search terms were used to ensure that all studies which met the inclusion criteria were captured in initial searches. The search strategy for the main electronic search (MEDLINE) is presented in Appendix A. It was revised as necessary for the other databases. (Full searches for these databases are available upon request.)

\subsection{Data selection}

First, duplicates were identified and removed by the first author. Next, the titles of the articles were screened for inclusion by the first author (EP) and a group of seven second readers. Each second reader received written instructions that explained the research question, the inclusion and exclusion criteria and how to include articles based on the title. Any disagreement about inclusion of an articles based on the title was discussed and resolved through consensus between the first author and the second reader.

Second, two authors (EP and SD) assessed the inclusion by abstract. Articles without abstract were excluded. EP and SD discussed doubtful in- or exclusion. The focus was on empirical studies involving doctors of the ethnic majority and patients of the ethnic minority (Table 2).

\section{[TABLE 2]}

Finally, the full texts of the remaining articles were screened for in- or exclusion by a medical doctor (EP) and an intercultural communication specialist (CA). In case of disagreement between the two researchers, the first author (EP) discussed the papers with the authors FS or SD until consensus was reached. The definitive and complete reading of all the full papers was done by EP.

\subsection{Data analysis and synthesis}

The review team agreed on what type of data to extract from the included articles, and one reviewer (EP) extracted the data and identified the CMO configurations in each study. The following information was culled: participant characteristics, methods used (i.e. qualitative vs. quantitative), country of research, study design, main results, frame of reference and level of contribution. 
Paternotte, E., Dulmen, S. van, Lee, N. van der, Scherpbier, A.J.J.A., Scheele, F. Factors influepæing intercultural doctor-patient communication: a realist review. Patient Education and Counseling: 2015, 98(4), 420-445

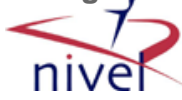

We assessed the level of contribution based on relevance and rigor of the articles. This was not to judge the methodological quality of the articles, but to give insight into their degree of importance for answering our specific research question. The rigor was indicated by assessing whether 'the method used to generate that particular piece of data was credible and trustworthy' (high or low). The relevance was indicated by assessing whether 'the article contributed to answering our research question' (high or low). The two assessments were combined in one score for the level of contribution: high (high/high), medium (high/low or low/high) or low (low/low). For example, if the paper included clearly described and trustworthy methods, the level of contribution in terms of rigor was assessed as high. If a paper about ICC described only a small section of ICC between the doctor and the patient and answered the research question only partly, the level of contribution in terms of relevance was assessed as low.

Data synthesis was undertaken by the first author (EP), and synthesis results were regularly shared and discussed within the research team to ensure validity and consistency. The research team discussed all the extracted data to find overarching categories in the context-mechanismoutcome model. Specifically, we attempted to identify factors which could facilitate or hinder the communication and then sought to explain these and to formulate a relevant framework.

\section{RESULTS}

\subsection{Characteristics}

For this realist review we considered 51,179 articles, 145 of which met the final inclusion criteria. The included articles were written in English, French, German, Italian and Norwegian. All but 5 articles [31], [32], [33], [34] and [35] were from western countries. The 5 remaining articles were from Israel [31] and South Africa [32], [33], [34] and [35]. The selection process and subsequent categorization are summarized in Fig. 1. Appendix B presents the characteristics of the included articles and the level of contribution.

\section{[FIGURE 1]}

After discussion within the research team, we identified the emerging factors influencing ICC and categorized them in terms of contexts, mechanisms and outcomes of ICC. The context factors are the four major communication challenges of ICC: language differences, differences in perception of illness and disease, different perceptions of the social component of health communication, and doctors' and patients' prejudices and assumptions.

Following these challenges, we described the mechanisms by objectives, specific skills and core skills. Core skills can be regarded as the main skills of communication doctors should use in their consultation, for example listening. Specific communication skills are the skills a doctor needs in specific situations or contexts, for example in issues with gender, cultural and social diversity or end-of-life care [4]. The outcome is described as a barrier or facilitator for the communication (Fig. 2). These descriptions included the outcome in the perception of the doctor or the patient, for example feelings of frustration or satisfaction. The overall results are shown in Table 3. In the following paragraphs we describe the challenges and their mechanisms with examples. 
Paternotte, E., Dulmen, S. van, Lee, N. van der, Scherpbier, A.J.J.A., Scheele, F. Factors influepæing intercultural doctor-patient communication: a realist review. Patient Education and Counseling: 2015, 98(4), 420-445

\section{[FIGURE 2][TABLE 3]}

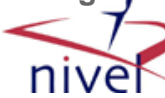

\subsection{LANGUAGE DIFFERENCES}

The influence of language on the communication was mentioned frequently. Language differences literally caused miscommunication [33], [34], [36], [37], [38], [39], [40], [41], [42], [43], [44], [45], [46], [47], [48], [49], [50], [51], [52], [53], [54], [55], [56], [57], [58], [59], [60], [61], [62], [63], [64], [65] and [66]. Language differences were seen as important barriers of ICC, because of their relation with misunderstandings, frustration and situations in which it is not possible for the doctor to achieve shared decision-making.

For doctors, the objectives during a consultation were found to focus on understanding the patient and on knowledge of languages. This did not mean that the doctor should be able to speak all the languages of their patients; communication was facilitated when a doctor knew a few words of the language of the patient, because this helped to build a relationship with the patient [67], [68], [69] and [70].

During an intercultural conversation, the doctor needed specific skills to facilitate the communication. These skills mainly involved various ways of providing explanations and the ability to use extra attributes, such as pictures or an interpreter, in case of language differences.

Besides these specific skills, the included articles mentioned many communication skills that are useful in any doctor-patient conversation. These core skills were, for example, listening [47], [71], [72], [73], [74], [75], [76], [77], [78], [79], [80], [81], [82] and [83] and explaining, or avoiding medical jargon. Also, both patients and doctors felt more satisfied when the doctor checked the patient's understanding [58], [72], [84], [85], [86], [87], [88] and [89]. For example, paraphrasing and repeating the patient's exact words encouraged the patient to elaborate on their concerns [90].

Together, the communication objectives, the core skills and the specific skills would help to facilitate successful communication between doctors and patients. This is confirmed by the large number of articles which reported that patients found it more important for the doctor to have good language skills than to have the same ethnicity as the patient [36], [52], [55], [65], [66], [82], [91], [92], [93], [94], [95] and [96].

\subsection{DIFFERENCES IN CULTURAL PERCEPTION OF ILLNESS AND DISEASE}

As described in many articles, language is not the only challenge in ICC. Even between patients and doctors who spoke the same language, misunderstandings were common if their ethnic background differed, because these doctors and patients had different cultural paradigms. Consequently, their perceptions of illness and health were influenced by different religions, norms and values [35], [45], [48], [95], [97], [98], [99], [100], [101], [102], [103], [104] and [105]. Patients who had a hierarchical worldview, for instance, were not used to reflecting on their own thoughts about illness, which made it difficult for them to answer some questions commonly asked by doctors [38] and [106]. Some patients used religious arguments to explain their condition. For example, they replaced the cause of a disease with another etiology which was more in line with their religious beliefs [100]. 
Paternotte, E., Dulmen, S. van, Lee, N. van der, Scherpbier, A.J.J.A., Scheele, F. Factors influepring intercultural doctor-patient communication: a realist review. Patient Education and Counseling: 2015, 98(4), 420-445

The objectives that need to be reached to deal with these challenges were identified as knowledge and awareness of cultural differences, management of the patient's expectations of the health care system, mutual understanding [40], [48], [75], [78], [81], [85], [91], [107], [108] and [109], and patient-centered care.

Cultural awareness entails specific skills such as recognizing and knowing one's own and other people's cultural identities and beliefs. ICC was influenced both by the doctor's level of selfawareness and by his or her level of awareness of the patient's culture. Two studies reported that ICC was hindered by the lack of cultural awareness of both patient and doctor, which prevented them from understanding each other's deeply entrenched attitudes [47] and [52]. In four studies, ICC was facilitated when the doctor was aware of his own culture [31], [43], [110] and [111].

For doctors, another main objective in ICC was to manage patients' expectations of the health care system. For example, it was often reported that patients with different ethnic backgrounds did not know how to enter the healthcare system, how to make an appointment with the doctor or which doctor they should visit. In this context, the patients' insufficient organizational and medical knowledge caused them, for example, to visit the wrong doctor, which led to unsatisfactory communication outcomes [35], [40], [45], [48], [67], [81], [102], [104], [112], [113], [114] and [115]. It also contributed to feelings of frustration among doctors [48], [68], [70], [116] and [117], indicating that it would be a valuable specific skill for doctors in ICC to be able to recognize misunderstandings caused by cultural differences and, at the same time, to recognize a patient's expectations of the health care system.

Some articles mentioned that patient-centered communication could be the solution to barriers in ICC [96], [114], [118], [119] and [120]. Many doctors learned to practice patient-centered communication in terms of shared decision-making [64], [121], [122], [123], [124] and [125] and activating patients [34], [91], [109], [126], [127], [128] and [129]. Some studies found that shared decision-making also facilitated communicationin ICC, but other articles showed that patients of ethnic minorities, especially the non-western minorities, viewed the doctor as a person with a high social status and regarded it as disrespectful to contradict the doctor (paternalism) [43], [72], [79], [88], [90], [97], [122], [123], [124], [127], [130], [131], [132], [133], [134], [135], [136], [137], [138], [139] and [140]. In these cases, patient-centered communication might be a effective approach for ICC.

To deal with cultural differences in the perception of illness and disease, doctors were found to need several core skills, such as an open attitude [141] and [142], empathic communication [79], [93], [108], [122], [128], [143], [144], [145], [146], [147], [148] and [149], showing trust [42], [47], [78], [79], [142], [150] and [151] and being respectfull to the patient [54], [73], [76], [78], [79], [80], [83], [84], [87], [105], [114] and [152]. Also, time management [54], [76], [79], [80], [81], [82], [83], [87], [89], [105], [107], [108] and [152], providing explanations [34], [73], [76], [80], [85], [100], [102], [107], [108], [119], [149] and [152] and giving appropriate information [63], [69], [84], [87], [110], [114], [121], [127], [131], [132], [147], [153], [154] and [155] were mentioned as core skills for a doctor to facilitate ICC communication. 
Paternotte, E., Dulmen, S. van, Lee, N. van der, Scherpbier, A.J.J.A., Scheele, F. Factors influepring intercultural doctor-patient communication: a realist review. Patient Education and Counseling: 2015, 98(4), 420-445

\subsection{Social component of communication}

Another contextual (influencing) factor was the social component of ICC. Many ethnic minority patients considered it very important that the doctor showed interest in the wellbeing of the family or talked with the family when present [31], [40], [134] and [156] and tried to build trust in the relation with the patient [54]. This was an important contextual issue, but often the doctors did not recognize it, as they were used to directing their communication at the individual patient rather than at the family (specific skill) [38], [51] and [157]. For patients, their illnesses were connected to their community context and family; relations, culture and values were inseparable [39], [57], [64], [89], [156], [158], [159], [160] and [161]. Here miscommunication (outcome) occurred because doctors and patients had different perceptions of the role of the family. Therefore, knowledge about expectations and habits of the patient and his family [35], [81], [94], [102], [114], [162], [163] and [164] were described as specific skills. The core skills to reach the objectives were defined as building a relationship with and handling the emotions of the patients and their families. When the doctor knew the situation and context of the patient, he adapted his behavior to expectations of the patient, which improved the communication outcome [39], [40], [43], [57] and [113].

\subsection{Prejudices and assumptions}

The last identified challenges for the communication were the prejudices and assumptions of doctors about ethnic minority patients. This contextural factor had similar objectives as the context factor 'differences in cultural perception'; i.e. knowledge and awareness of the cultural differences. For these objectives, the specific skills recognized in the included articles were demonstrating trustworthiness and the doctor's awareness of his or her own assumptions, sometimes caused by previous experiences [94]. Dealing with previous experiences of patients was seen as a core skill of the doctor. These experiences of patients were mostly negative and therefore recognizing them was important to facilitate the communication [32], [42], [76], [151], [165] and [166]. For example, some doctors generalized their thoughts about patients of one ethnicity under the same heading [141]. As a reaction to this mechanism, some patients felt discriminated and treated unequally [102], [118], [132], [167], [168] and [169]. ICC was influenced both by the doctor's lack of awareness and by the patient's feelings.

\section{DISCUSSION AND CONCLUSION}

\subsection{Discussion}

The aim of this review was to summarize the current knowledge on the factors that influence ICC and to explore the mechanisms through which these factors influence ICC. The use of a realist synthesis provided the opportunity to include a broad range of papers and to explore the context, mechanisms and outcomes in each of the included articles. From a total of 145 included articles, we derived four communication challenges (contextual factors) and several objectives and communication skills (mechanisms) whose absence or presence constituted barriers or facilitators, respectively, for ICC (outcomes). The communication skills could be divided into core communication skills, which doctors should use in any interaction with patients, and specific communication skills for intercultural doctor-patient communication. Reflecting on our research question, we arranged the influencing factors in a framework (Fig. 
Paternotte, E., Dulmen, S. van, Lee, N. van der, Scherpbier, A.J.J.A., Scheele, F. Factors influepring intercultural doctor-patient communication: a realist review. Patient Education and Counseling: 2015, 98(4), 420-445

2) that clarifies which skills should be trained to enable doctors to deal with each of the challenges of ICC.

One of the new insights of this realist review is that the findings of the ICC literature can be translated into an educational framework in response to 4 contextual challenges. Another new insight is that the framework distinguishes between core communication skills that are largely covered by training programs for patient-centered communication, and ICC-specific communication skills that can be developed as an extension of the existing training programs. Doctors who want to facilitate successful intercultural communication with patients should be aware of the contextual challenges and should acquire and use the core and specific communication skills to reach the communication objectives and overcome the contextual challenges. We do not mean to imply that doctors will need to develop proficiencies in each of the skills equally. For example, doctors who know nothing about the patient's culture (specific skills) might still provide excellent care by employing the appropriate core skills, which may well lead to a positive communication outcome. Also, the cultural content of some encounters may be more challenging than the content of others. Rather than one discrete skill, an integrated set of specific communication skills emerged as the key to successful ICC.

We have provided insights into the core communication skills and the specific communication skills that are important for ICC which can be translated into practical points for training. Since effective ICC seemed to have many similarities with patient-centered communication, the core communication skills are similar to the patient-centered communication skills as provided in the six function model of medical communication by de Haes and Bensing [170]. This finding is in line with findings of Teal et al. in their article about culturally competent communication [9]. However, while patient-centered communication emphasizes improving the quality of individual communication [170], ICC stresses equitable distribution of quality communication among diverse ethnic groups, highlighting a different focus. Since patient-centeredness is increasingly regarded as crucial for the delivery of high quality care by doctors [171], the recognition of the similarities between patient-centeredness and ICC is important.

Our findings in this review support earlier research in the area of ICC. The review of Schouten et al.

[12] showed five key predictors of challenges in ICC, two of which are comparable with our results: cultural differences in explanatory models of health and illness and linguistic barriers. Schouten et al., however, did not provide mechanisms for counteracting these challenges [12]. Furthermore, our results have similarities with the model of culturally competent communication (CCC) of Teal et al.

[9], who found four critical elements of CCC, i.e. repertoire, awareness, adaptability and knowledge, and gave a very clear summary of the main CCC skills [9]. In contrast to the study of Teal et al., however, we also found that language was a potential influencing factor of ICC. What our study added to the study of Teal et al. is the systematic search and the fact that we identified specific and core communication skills, which can be translated into communication training.

The anthropological research of Arasaratam et al. 
Paternotte, E., Dulmen, S. van, Lee, N. van der, Scherpbier, A.J.J.A., Scheele, F. Factors influepæing intercultural doctor-patient communication: a realist review. Patient Education and Counseling: 2015, 98(4), 420-445

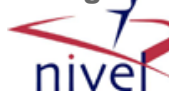

[172] described several theories of ICC. One of these theories, the system theory approach [173], distinguishes between cultural competence and ICC competence. This approach explained that being competent in a particular cultural context does not necessarily imply ICC competence and that in an intercultural context the adaptability of a person is displayed in the ability to be flexible in unfamiliar cultural situations [173]. We think that this approach emphasizes the importance of our research on ICC and of the development of training in this specific area.

As described earlier, ICC has gained attention during the last years, but it has not yet structurally been implemented into all medical curricula of multi-ethnic societies. This situation does not comply with our multi-ethnic societies' demand for doctors with cultural diversity competences [13], [14] and [15]. Strategies to encourage reflective practice in the context of ICC skills training may be more successful than overt attempts to change attitudes [174]. A skill-based approach may therefore be less threatening than a theory-based approach and can be reinforced by assessment of competencies and behavior.

The realist perspective of this review provided the opportunity to examine a wide range of papers in the complex field of ICC and to look at this complex area. This helped to gain insight into the process of ICC. The results did not focus on healthcare outcomes, but on factors which influenced the communication process, in order to identify barriers and facilitators of effective communication in the context of ethnic differences between the doctor and the patient. A strength of this study was the broad research question and search, which enabled us to include many papers about ICC in healthcare. Also, the results were strengthened by the inclusion of studies on both the doctors' and the patients' perspectives, because both parties influence the communication and therefore both voices need to be heard. However, as the search was so broad, it was not possible to include the references of the included articles as well, although we expect that most of them were already included as primary results of our broad search. Another limitation was that the healthcare workers we focused on in this review were doctors; while there are many more healthcare workers who need to deal with the difficulties of ICC in practice, our special focus is due to our interest in developing training programs for doctors. This particular interest also explains why we limited our search to studies that did not include the use of interpreters, since this could influence the interaction and can give bias for answering our research question.

As in all systematic reviews, selection and publication bias is a possible limitation of the present study. However, we aimed to prevent this by extending our search beyond articles written in English and by placing no restrictions on the year of publication. Another limitation could be that we did not test our theory by means of secondary searches. Also, we were not able to distinguish between the different ethnicities within the included articles. As a consequence, we did not describe the interethnic differences. Nor did we investigate the effects of non-verbal communication per se, which also influences the outcome of intercultural doctorpatient communication.

This research identified a number of influencing factors that shape the ICC process between doctors and patients. Future research might focus on how these factors could be used and managed at a practical level. First, this would involve checking our findings by examining reallife consultations. Second, the mechanisms we identified could be used for the development of 
Paternotte, E., Dulmen, S. van, Lee, N. van der, Scherpbier, A.J.J.A., Scheele, F. Factors influepæing intercultural doctor-patient communication: a realist review. Patient Education and Counseling: 2015, 98(4), 420-445

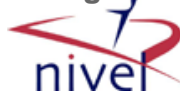

communication training and assessment for doctors. As Kai et al. already stated in 2001, uncertainty about the assessment of cultural diversity still needs attention [16].

\subsection{Conclusion}

We identified communication challenges, objectives and skills that result in barriers or facilitators for intercultural doctor-patient communication. To overcome the challenges, training for doctors should focus on the core communication skills and the specific communication skills that can produce positive outcomes for ICC. The core communication skills required for ICC were similar to the skills for patient-centered communication, but ICC was more susceptible to imbalances in the communication process when cultural differences in the perception of illness and disease were ignored. The insights into the specific skills required to meet ICC challenges in health care provide important information for the development of communication training for doctors.

\subsection{Implications for practice}

Training programs for improving intercultural doctor-patient communication can be developed as an extension of the existing training programs for patient-centered communication. The description of objectives and specific and core communication skills can be used to translate of ICC theory into clinical practice.

The main educational objectives per contextual challenge are as follows:

- Language differences: knowledge of languages and recognizing misunderstanding.

- Difference in perception of illness and disease: patient centered communication, awareness of cultural differences, doctors' awareness of their own culture and expectation management.

- Social component of communication: knowledge about the role of the patient's family.

- Prejudices and assumptions: awareness of one's own assumptions.

\section{Funding/support}

None.

\section{Ethical approval}

Not applicable.

\section{Conflict of interest statement}

The authors report no conflict of interest, no financial competing interests and no non-financial competing interests. The authors alone are responsible for the content and writing of the paper.

\section{Acknowledgments}

We are grateful to the persons who helped with the inclusion of articles, Anneli Mellblom, Alessandro Bottacini, Karsten van Loon, Noera Kieviet, Sanne Schinkel en Lex Paternotte. 
Paternotte, E., Dulmen, S. van, Lee, N. van der, Scherpbier, A.J.J.A., Scheele, F. Factors influepæing intercultural doctor-patient communication: a realist review. Patient Education and Counseling: 2015, 98(4), 420-445

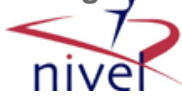

Special thanks are conveyed to Cibele Alvim, intercultural communication specialist, who helped with all the work of selecting the full-text. We are thankful to Hans Ket and Chantal de Haan, information specialists of the Sint Lucas Andreas hospital, who helped with the database searches. Also, Marianne Kerssens, assistant librarian of the Sint Lucas Andreas Hospital, is gratefully acknowledged for collecting all full texts, which were made available by the library of the Sint Lucas Andreas Hospital. We thank Professor Jan Illing for her feedback on the whole paper, but especially on the used methods. Finally, we would like to thank Lisette van Hulst for her writing assistance.

\section{APPENDiX A EN B}

\section{REFERENCES}

[1] Frenk J, Chen L, Bhutta ZA, Cohen J, Crisp N, Evans T, et al. Health professionals for a new century: transforming education to strengthen health systems in an interdependent world. Lancet 2010;376:1923-58.

[2] Barrier PA, Li JT, Jensen NM. Two words to improve physician-patient communication: what else? Mayo Clin Proc 2003;78:211-4.

[3] Stewart M, Brown JB, Boon H, Galajda J, Meredith L, Sangster M. Evidence on patient-doctor communication. Cancer Prev Control 1999;3:25-30.

[4] von FM, Silverman J, Cushing A, Quilligan S, Salisbury H, Wiskin C. UK consensus statement on the content of communication curricula in under-graduate medical education. Med Educ 2008;42:1100-7.

[5] Ferguson WJ, Candib LM. Culture, language, and the doctor-patient relation-ship. Fam Med 2002;34:353-61.

[6] Alderliesten ME, Stronks K, van Lith JM, Smit BJ, van der Wal MF, Bonsel GJ, et al. Ethnic differences in perinatal mortality. A perinatal audit on the role of substandard care. Eur J Obstet Gynecol Reprod Biol 2008;138:164-70.

[7] Kleinman A, Eisenberg L, Good B. Culture, illness, and care: clinical lessons from anthropologic and cross-cultural research. Ann Intern Med 1978;88:251-8.

[8] Boas F. The mind of primitive man. NewYork:; 2014. 1911 (cited in Klineberg 1980, 36-7 (Ref Type: Generic)).

[9] Teal CR, Street RL. Critical elements of culturally competent communication in the medical encounter: a review and model. Soc Sci Med 2009;68:533-43.

[10] Weissman JS, Betancourt J, Campbell EG, Park ER, Kim M, Clarridge B, et al. Resident physicians' preparedness to provide cross-cultural care. J Amer Med Assoc 2005;294:1058-67.

[11] Park ER, Betancourt JR, Miller E, Nathan M, MacDonald E, Ananeh-Firempong O, et al. Internal medicine residents' perceptions of cross-cultural training. Barriers, needs, and educational recommendations. J Gen Intern Med 2006;21:476-80.

[12] Schouten BC, Meeuwesen L. Cultural differences in medical communication: a review of the literature. Patient Educ Couns 2006;64:21-34.

[13] Betancourt JR. Cultural competence and medical education: many names, many perspectives, one goal. Acad Med 2006;81:499-501.

[14] Dogra N, Reitmanova S, Carter-Pokras O. Teaching cultural diversity: current status in U.K., U.S., and Canadian medical schools. J Gen Intern Med 2010;25:S164-8.

[15] Paternotte E, Fokkema JP, van Loon KA, van DS, Scheele F. Cultural diversity: blind spot in medical curriculum documents, a document analysis. BMC Med Educ 2014;14:176.

[16] Kai J, Spencer J, Woodward N. Wrestling with ethnic diversity: toward empowering health educators. Med Educ 2001;35:262-71.

[17] Skelton JR, Kai J, Loudon RF. Cross-cultural communication in medicine: questions for educators. Med Educ 2001;35:257-61.

[18] Hamilton J. Intercultural competence in medical education-essential to acquire, difficult to assess. Med Teach 2009;31:862-5.

[19] Gregg J, Saha S. Losing culture on the way to competence: the use and misuse of culture in medical education. Acad Med 2006;81:542-7. 
Paternotte, E., Dulmen, S. van, Lee, N. van der, Scherpbier, A.J.J.A., Scheele, F. Factors influepæing intercultural doctor-patient communication: a realist review. Patient Education and Counseling: 2015, 98(4), 420-445

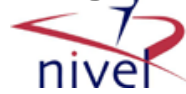

[20] Spencer J, Silverman J. Education for communication: much already known, so much more to understand. Med Educ 2001;35:188-90.

[21] Ho MJ, Yao G, Lee KL, Beach MC, Green AR. Cross-cultural medical education: can patientcentered cultural competency training be effective in non-West-ern countries. Med Teach 2008;30:719-21.

[22] Wong G, Greenhalgh T, Westhorp G, Buckingham J, Pawson R. RAMESES publication standards: realist syntheses. BMC Med 2013;11:21.

[23] Dogra N. Diversity in medicine and healthcare. Leicester: University of Leicester; 2014. Ref Type Online Source.

[24] Horvat L, Horey D, Romios P, Kis-Rigo J. Cultural competence education for health professionals. Cochrane Database Syst Rev 2014;5:CD009405.

[25] Burchard EG, Ziv E, Coyle N, Gomez SL, Tang H, Karter AJ, et al. The importance of race and ethnic background in biomedical research and clinical practice. N Engl J Med 2003;348:1170-5.

[26] Seeleman C, Suurmond J, Stronks K. Cultural competence: a conceptual framework for teaching and learning. Med Educ 2009;43:229-37.

[27] Gudykunst WB. Cross-cultural and intercultural communication. California State, USA: Palgrave Macmillan; 2014.

[28] Brinkman U, Weerdenbur van O. Intercultural readiness. Four competences for working across cultures. 1st ed. Hampshire, Great-Britain: Palgrave Macmillan; 2014.

[29] Wong G, Greenhalgh T, Westhorp G, Pawson R. Realist methods in medical education research: what are they and what can they contribute. Med Educ 2012;46:89-96.

[30] Pawson R. Evidence-based policy. A realist perspective. London: SAGE Pub-lications Ltd; 2006.

[31] Kushnir T, Bachner YG, Carmel S, Flusser H, Galil A. Pediatricians' communi-cation styles as correlates of global trust among Jewish and Bedouin parents of disabled children. J Dev Behav Pediatr 2008;29:18-25.

[32] Schlemmer A, Mash B. The effects of a language barrier in a South African district hospital. S Afr Med J 2006;96:1084-7.

[33] Levin ME. Language as a barrier to care for Xhosa-speaking patients at a South African paediatric teaching hospital. S Afr Med J 2006;96:1076-9.

[34] Krauss-Mars AH, Lachman P. Breaking bad news to parents with disabled children-a crosscultural study. Child Care Health Dev 1994;20:101-13.

[35] Herselman S. Some problems in health communication in a multicultural clinical setting: a South African experience. Health Commun 1996;8:153-70.

[36] August KJ, Nguyen H, Ngo-Metzger Q, Sorkin DH. Language concordance and patient-physician communication regarding mental health needs. J Am Geriatr Soc 2011;59:2356-62.

[37] Babitsch B, Braun T, Borde T, David M. Doctor's perception of doctor-patient relationships in emergency departments: what roles do gender and ethnicity play? BMC Health Serv Res 2008;8:82.

[38] Blochliger C, Tanner M, Hatz C, Junghanss T. Asylum seekers and refugees in ambulatory health care: communication between physician and patient. Praxis (Bern 1994) 1997;86:800-10.

[39] Carrion IV. Communicating terminal diagnoses to Hispanic patients. Palliat Support Care 2010;8:117-23.

[40] Cave A, Maharaj U, Gibson N, Jackson E. Physicians and immigrant patients. Cross-cultural communication. Can Fam Physician 1995;41:1685-90.

[41] Cheng WY, Blum P, Spain B. Barriers to effective perioperative communica-tion in indigenous Australians: an audit of progress since 1996. Anaesth Intensive Care 2004;32:542-7.

[42] Collins TC, Clark JA, Petersen LA, Kressin NR. Racial differences in how patients perceive physician communication regarding cardiac testing. Med Care 2002;40:127-34.

[43] Degni F, Suominen S, Essen B, El AW, Vehvilainen-Julkunen K. Communica- tion and cultural issues in providing reproductive health care to immigrant women: health care providers' experiences in meeting the needs of [cor- rected] Somali women living in Finland. J Immigr Minor Health 2012;14:330-43.

[44] Diamond LC, Tuot DS, Karliner LS. The use of Spanish language skills by physicians and nurses: policy implications for teaching and testing. J Gen Intern Med 2012;27:117-23.

[45] Dyregrov K. Intercultural communication in general practice. Tidsskr Nor Laegeforen 1997;117:2444-6.

[46] Garcia CM, Duckett LJ. No te entiendo y tu no me entiendes: language barriers among immigrant Latino adolescents seeking health care. J Cult Divers 2009;16:120-6. 
Paternotte, E., Dulmen, S. van, Lee, N. van der, Scherpbier, A.J.J.A., Scheele, F. Factors influepæing intercultural doctor-patient communication: a realist review. Patient Education and Counseling: 2015, 98(4), 420-445

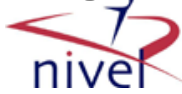

[47] Ge G, Burke N, Somkin CP, Pasick R. Considering culture in physician-patient communication during colorectal cancer screening. Qual Health Res 2009;19:778-89.

[48] Gerlach H, Abholz HH. Black patients and white family doctors. Z Allg med 2009;85:444-50.

[49] Gonzalez-Espada WJ, Ibarra MJ, Ochoa ER, Vargas PA. Multicultural medical encounters: the experience at a pediatric clinic. J Ark Med Soc 2006;102:227-9.

[50] Gonzalez HM, Vega WA, Tarraf W. Health care quality perceptions among foreign-born Latinos and the importance of speaking the same language. J Am Board Fam Med 2010;23:745-52.

[51] Gulati S, Watt L, Shaw N, Sung L, Poureslami IM, Klaassen R, et al. Communi-cation and language challenges experienced by Chinese and South Asian immigrant parents of children with cancer in Canada: implications for health services delivery. Pediatr Blood Cancer 2012;58:572-8.

[52] Gurnah K, Khoshnood K, Bradley E, Yuan C. Lost in translation: reproductive health care experiences of Somali Bantu women in Hartford, Connecticut. J Midwifery Womens Health 2011;56:340-6.

[53] Harmsen JA, Bernsen RM, Bruijnzeels MA, Meeuwesen L. Patients' evaluation of quality of care in general practice: what are the cultural and linguistic barriers. Patient Educ Couns 2008;72:155-62.

[54] Julliard K, Vivar J, Delgado C, Cruz E, Kabak J, Sabers H. What Latina patients don't tell their doctors: a qualitative study. Ann Fam Med 2008;6:543-9.

[55] Kale E, Finset A, Eikeland HL, Gulbrandsen P. Emotional cues and concerns in hospital encounters with non-Western immigrants as compared with Nor-wegians: an exploratory study. Patient Educ Couns 2011;84:325-31.

[56] Katz ML, James AS, Pignone MP, Hudson MA, Jackson E, Oates V, et al. Colorectal cancer screening among African American church members: a qualitative and quantitative study of patientprovider communication. BMC Public Health 2004;4:62.

[57] Kelly L, Brown JB. Listening to native patients. Changes in physicians' under-standing and behaviour. Can Fam Phys 2002;48:1645-52.

[58] Leng J, Lee T, Sarpel U, Lau J, Li Y, Cheng C, et al. Identifying the informational and psychosocial needs of Chinese immigrant cancer patients: a focus group study. Support Care Cancer 2012;20(12):3221-9.

[59] Moss B, Roberts C. Explanations, explanations, explanations: how do patients with limited English construct narrative accounts in multi-lingual, multi-ethnic settings, and how can GPs interpret them? Fam Pract 2005;22:412-8.

[60] Ngo-Metzger Q, Sorkin DH, Phillips RS, Greenfield S, Massagli MP, Clarridge B, et al. Providing high-quality care for limited English proficient patients: the importance of language concordance and interpreter use. J Gen Int Med 2007;22:324-30.

[61] O'Brien M, Shea J. Disparities in patient satisfaction among Hispanics: the role of language preference. J Immigr Minor Health 2011;13:408-12.

[62] Roberts C, Moss B, Wass V, Sarangi S, Jones R. Misunderstandings: a qualita-tive study of primary care consultations in multilingual settings, and educa-tional implications. Med Educ 2005;39:465-75.

[63] Sleath B, Rubin RH, Huston SA. Hispanic ethnicity, physician-patient com- munication, and antidepressant adherence. Compr Psychiatry 2003;44:198-204.

[64] Sudore RL, Landefeld CS, Perez-Stable EJ, Bibbins-Domingo K, Williams BA, Schillinger D. Unraveling the relationship between literacy, language profi-ciency, and patient-physician communication. Patient Educ Couns 2009;75:398-402.

[65] Wearn A, Goodyear-Smith F, Everts H, Huggard P. Frequency and effects of non-English consultations in New Zealand general practice. N Z Med J 2007;120:U2771.

[66] Weitzman PF, Chang G, Reynoso H. Middle-aged and older Latino American women in the patient-doctor interaction. J Cross Cult Gerontol 2004;19:221- 39.

[67] Brugge D, Edgar T, George K, Heung J, Laws MB. Beyond literacy and numeracy in patient provider communication: focus groups suggest roles for empower- ment, provider attitude and language. BMC Public Health 2009;9:354.

[68] Burbano O'Leary SC, Federico S, Hampers LC. The truth about language barriers: one residency program's experience. Pediatrics 2003;111:e569-73.

[69] Degan M, Salviato D. Communication difficulties between health profes-sionals and foreign women in obstetrical and gynecological departments. Prof Inferm 2003;56:201-11.

[70] Wright CM. Language and communication problems in an Asian community. J R Coll Gen Pract 1983;33:101-4. 
Paternotte, E., Dulmen, S. van, Lee, N. van der, Scherpbier, A.J.J.A., Scheele, F. Factors influepæing intercultural doctor-patient communication: a realist review. Patient Education and Counseling: 2015, 98(4), 420-445

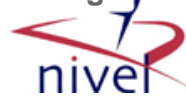

[71] Jensen JD, King AJ, Guntzviller LM, Davis LA. Patient-provider communication and low-income adults: age, race, literacy, and optimism predict communi-cation satisfaction. Patient Educ Couns 2010;79:30-5.

[72] Johnson RL, Saha S, Arbelaez JJ, Beach MC, Cooper LA. Racial and ethnic differences in patient perceptions of bias and cultural competence in health care. J Gen Intern Med 2004;19:101-10.

[73] Korthuis PT, Saha S, Fleishman JA, McGrath MM, Josephs JS, Moore RD, et al. Impact of patient race on patient experiences of access and communication in HIV care. J Gen Intern Med 2008;23:2046-52.

[74] Levinson W, Hudak PL, Feldman JJ, Frankel RM, Kuby A, Bereknyei S, et al. It's not what you say . . . racial disparities in communication between orthopedic surgeons and patients. Med Care 2008;46:410-6.

[75] Morales LS, Cunningham WE, Brown JA, Liu H, Hays RD. Are Latinos less satisfied with communication by health care providers. J Gen Intern Med 1999;14:409-17.

[76] Moreno G, Morales LS. Hablamos Juntos (Together We Speak): interpreters, provider communication, and satisfaction with care. J Gen Intern Med 2010;25:1282-8.

[77] Piette JD, Schillinger D, Potter MB, Heisler M. Dimensions of patient-provider communication and diabetes self-care in an ethnically diverse population. J Gen Intern Med 2003;18:624-33.

[78] Smith AK, Davis RB, Krakauer EL. Differences in the quality of the patient-physician relationship among terminally ill African-American and white patients: impact on advance care planning and treatment preferences. J Gen Intern Med 2007;22:1579-82.

[79] Song L, Hamilton JB, Moore AD. Patient-healthcare provider communication: perspectives of African American cancer patients. Health Psychol 2011;31(5):539-47.

[80] Wallace LS, DeVoe JE, Heintzman JD, Fryer GE. Language preference and perceptions of healthcare providers' communication and autonomy making behaviors among Hispanics. J Immigr Minor Health 2009;11:453-9.

[81] Wiking E, Saleh-Stattin N, Johansson SE, Sundquist J. A description of some aspects of the triangular meeting between immigrant patients, their inter-preters and GPs in primary health care in Stockholm, Sweden. Fam Pract 2009;26:377-83.

[82] Wiking E, Saleh-Stattin N, Johansson SE, Sundquist J. Immigrant patients' experiences and reflections pertaining to the consultation: a study on patients from Chile, Iran and Turkey in primary health care in Stockholm, Sweden. Scand J Caring Sci 2009;23:290-7.

[83] Wilkins V, Elliott MN, Richardson A, Lozano P, Mangione-Smith R. The association between care experiences and parent ratings of care for different racial, ethnic, and language groups in a Medicaid population. Health Serv Res 2011;46:821-39.

[84] Abbe M, Simon C, Angiolillo A, Ruccione K, Kodish ED. A survey of language barriers from the perspective of pediatric oncologists, interpreters, and parents. Pediatr Blood Cancer 2006;47:819-24.

[85] Harmsen H, Meeuwesen L, van WJ, Bernsen R, Bruijnzeels M. When cultures meet in general practice: intercultural differences between GPs and parents of child patients. Patient Educ Couns 2003;51:99-106.

[86] Kline F, Acosta FX, Austin W, Johnson Jr RG. The misunderstood Spanish-speaking patient. Am J Psychiatry 1980;137:1530-3.

[87] Scholl JC, Wilson JB, Hughes PC. Expression of patients' and providers' identities during the medical interview. Qual Health Res 2011;21:1022- 32.

[88] Shahid S, Finn LD, Thompson SC. Barriers to participation of Aboriginal people in cancer care: communication in the hospital setting. Med J Aust 2009;190:574-9.

[89] Shrank WH, Kutner JS, Richardson T, Mularski RA, Fischer S, Kagawa-Singer M. Focus group findings about the influence of culture on communication preferences in end-of-life care. J Gen Intern Med 2005;20:703-9.

[90] Erzinger S. Communication between Spanish-speaking patients and their doctors in medical encounters. Cult Med Psychiatry 1991;15:91-110.

[91] Davies B, Contro N, Larson J, Widger K. Culturally-sensitive information-sharing in pediatric palliative care. Pediatrics 2010;125:e859-65.

[92] Fernandez A, Schillinger D, Grumbach K, Rosenthal A, Stewart AL, Wang F, et al. Physician language ability and cultural competence. An exploratory study of communication with Spanishspeaking patients. J Gen Intern Med 2004;19:167-74.

[93] Hooper EM, Comstock LM, Goodwin JM, Goodwin JS. Patient characteristics that influence physician behavior. Med Care 1982;20:630-8. 
Paternotte, E., Dulmen, S. van, Lee, N. van der, Scherpbier, A.J.J.A., Scheele, F. Factors influepæing intercultural doctor-patient communication: a realist review. Patient Education and Counseling: 2015, 98(4), 420-445

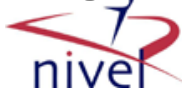

[94] Sleath B, Rubin RH, Campbell W, Gwyther L, Clark T. Ethnicity and physician- older patient communication about alternative therapies. J Altern Comple-ment Med 2001;7:329-35.

[95] Sleath B, Rubin RH. Gender, ethnicity, and physician-patient communication about depression and anxiety in primary care. Patient Educ Couns 2002;48:243-52.

[96] Ward B, Ellis J, Anderson K. Barriers to the provision of home and community care services to culturally and linguistically diverse populations in rural Australia. Aust J Prim Health 2005;11:147-55.

[97] Berkman CS, Ko E. Preferences for disclosure of information about serious illness among older Korean American immigrants in New York City. J Palliat Med 2009;12:351-7.

[98] Butow PN, Sze M, Dugal-Beri P, Mikhail M, Eisenbruch M, Jefford M, et al. From inside the bubble: migrants' perceptions of communication with the cancer team. Support Care Cancer 2010;19:281-90.

[99] Probst JC, Laditka SB, Moore CG, Harun N, Powell MP. Race and ethnicity differences in reporting of depressive symptoms. Adm Policy Ment Health 2007;34:519-29.

[100] Sheets KM, Baty BJ, Vazquez JC, Carey JC, Hobson WL. Breaking difficult news in a crosscultural setting: a qualitative study about Latina mothers of children with down syndrome. J Genet Couns 2012;21:582-90.

[101] Sims CM. Ethnic notions and healthy paranoias: understanding of the context of experience and interpretations of healthcare encounters among older Black women. Ethn Health 2010;15:495-514.

[102] Suurmond J, Uiters E, de Bruijne MC, Stronks K, Essink-Bot ML. Negative health care experiences of immigrant patients: a qualitative study. BMC Health Serv Res 2011;11:10.

[103] van Wieringen JC, Harmsen JA, Bruijnzeels MA. Intercultural communication in general practice. Eur J Public Health 2002;12:63-8.

[104] Villagran M, Hajek C, Zhao X, Peterson E, Wittenberg-Lyles E. Communication and culture: predictors of treatment adherence among Mexican immigrant patients. J Health Psychol 2012;17:44352.

[105] Wallace LS, DeVoe JE, Rogers ES, Protheroe J, Rowlands G, Fryer Jr GE. Digging deeper: quality of patient-provider communication across Hispanic sub-groups. BMC Health Serv Res 2009;9:240.

[106] Ruppen W, Bandschapp O, Urwyler A. Language difficulties in outpatients and their impact on a chronic pain unit in Northwest Switzerland. Swiss Med Wkly 2010;140:260-4.

[107] David RA, Rhee $M$. The impact of language as a barrier to effective health care in an underserved urban Hispanic community. Mt Sinai J Med 1998;65:393-7.

[108] Meeuwesen L, Harmsen JA, Bernsen RM, Bruijnzeels MA. Do Dutch doctors communicate differently with immigrant patients than with Dutch patients. Soc Sci Med 2006;63:2407-17.

[109] Schouten BC, Meeuwesen L, Harmsen HA. GPs' interactional styles in con-sultations with Dutch and ethnic minority patients. J Immigr Minor Health 2009;11:468-75.

[110] Manfredi C, Kaiser K, Matthews AK, Johnson TP. Are racial differences in patient-physician cancer communication and information explained by background, predisposing, and enabling factors. J Health Commun 2010;15:272-92.

[111] Quinn GP, Jimenez J, Meade CD, Munoz-Antonia T, Gwede CK, Castro E, et al. Enhancing oncology health care provider's sensitivity to cultural communica- tion to reduce cancer disparities: a pilot study. J Cancer Educ 2011;26:322-5.

[112] Arai Y, Farrow S. Access, expectations and communication: Japanese mothers' interaction with GPs in a pilot study in North London. Public Health 1995;109:353-61.

[113] Rosenberg E, Richard C, Lussier MT, Abdool SN. Intercultural communication competence in family medicine: lessons from the field. Patient Educ Couns 2006;61:236-45.

[114] Singh-Carlson S, Neufeld A, Olson J. South Asian immigrant women's experi-ences of being respected within cancer treatment settings. Can Oncol Nurs J 2010;20:188-98.

[115] Stevens GD, Shi L. Effect of managed care on children's relationships with their primary care physicians: differences by race. Arch Pediatr Adolesc Med 2002;156:369-77.

[116] Favrat B, Francillon C, Burnand B, Pecoud A, Decrey H. Does physician's satisfaction with an initial consultation differ according to the patient's origin?. A prospective study. Schweiz Med Wochenschr 1994;124: 1955-8.

[117] Goldstein NE, Concato J, Bradley EH, O'Leary JR, Fried TR. Doctor-patient communication about prognosis: the influence of race and financial status. J Palliat Med 2005;8:998-1004.

[118] Gerlach H, Abholz HH, Koc G, Yilmaz M, Becker N. As a migrant i wish not to be treated differently Focus-groups on the experience of patients with migration background from Turkey. Z Allg med 2012;88:77-85. 
Paternotte, E., Dulmen, S. van, Lee, N. van der, Scherpbier, A.J.J.A., Scheele, F. Factors influepæing intercultural doctor-patient communication: a realist review. Patient Education and Counseling: 2015, 98(4), 420-445

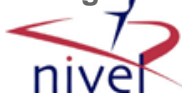

[119] Mosen DM, Carlson MJ, Morales LS, Hanes PP. Satisfaction with provider communication among Spanish-speaking medicaid enrollees. Ambul Pediatr 2004;4:500-4.

[120] Street Jr RL, O'Malley KJ, Cooper LA, Haidet P. Understanding concordance in patient-physician relationships: personal and ethnic dimensions of shared identity. Ann Fam Med 2008;6:198-205.

[121] Kokanovic R, Manderson L. Exploring doctor-patient communication in immigrant Australians with type 2 diabetes: a qualitative study. J Gen Intern Med 2007;22:459-63.

[122] Meeuwesen L, Tromp F, Schouten BC, Harmsen JA. Cultural differences in managing information during medical interaction: how does the physician get a clue. Patient Educ Couns 2007;67:183-90.

[123] Nguyen GT, Barg FK, Armstrong K, Holmes JH, Hornik RC. Cancer and communication in the health care setting: experiences of older Vietnamese immigrants, a qualitative study. J Gen Intern Med 2008;23:45-50.

[124] Schouten BC, Meeuwesen L, Tromp F, Harmsen HA. Cultural diversity in patient participation: the influence of patients' characteristics and doctors' communicative behaviour. Patient Educ Couns 2007;67:214-23.

[125] Watt L, Dix D, Gulati S, Sung L, Klaassen RJ, Shaw NT, et al. Family-centred care: a qualitative study of Chinese and South Asian immigrant parents' experiences of care in paediatric oncology. Child Care Health Dev 2011;39(2):185-93.

[126] Alegria M, Sribney W, Perez D, Laderman M, Keefe K. The role of patient activation on patientprovider communication and quality of care for US and foreign born Latino patients. J Gen Intern Med 2009;24:534-41.

[127] Gordon HS, Street Jr RL, Sharf BF, Souchek J. Racial differences in doctors' information-giving and patients' participation. Cancer 2006;107:1313-20.

[128] Seijo R, Gomez H, Freidenberg J. Language as a communication barrier in medical care for Hispanic patients. Hispanic J Behav Sci 1991;13:363-76.

[129] Siminoff LA, Graham GC, Gordon NH. Cancer communication patterns and the influence of patient characteristics: disparities in information-giving and affective behaviors. Patient Educ Couns 2006;62:355-60.

[130] Cooper-Patrick L, Gallo JJ, Gonzales JJ, Vu HT, Powe NR, Nelson C, et al. Race, gender, and partnership in the patient-physician relationship. J Amer Med Assoc 1999;282:583-9.

[131] Cox ED, Nackers KA, Young HN, Moreno MA, Levy JF, Mangione-Smith RM. Influence of race and socioeconomic status on engagement in pediatric primary care. Patient Educ Couns 2012;87:319-26.

[132] Hausmann LR, Hannon MJ, Kresevic DM, Hanusa BH, Kwoh CK, Ibrahim SA. Impact of perceived discrimination in healthcare on patient-provider com-munication. Med Care 2011;49:62633.

[133] Hausmann LR, Hanusa BH, Kresevic DM, Zickmund S, Ling BS, Gordon HS, et al. Orthopedic communication about osteoarthritis treatment: does pa-tient race matter? Arthritis Care Res (Hoboken) 2011;63:635-42.

[134] Hawley ST, Janz NK, Hamilton A, Griggs JJ, Alderman AK, Mujahid M, et al. Latina patient perspectives about informed treatment decision making for breast cancer. Patient Educ Couns 2008;73:363-70.

[135] Horn IB, Mitchell SJ, Joseph JG, Wissow LS. African-American parents' per-ceptions of partnership with their child's primary care provider. J Pediatr 2011;159:262-7.

[136] Jean-Pierre P, Fiscella K, Griggs J, Joseph JV, Morrow G, Carroll J, et al. Race/ ethnicity-based concerns over understanding cancer diagnosis and treat-ment plan. J Natl Med Assoc 2010;102:1849.

[137] Johnson RL, Roter D, Powe NR, Cooper LA. Patient race/ethnicity and quality of patientphysician communication during medical visits. Am J Public Health 2004;94:2084-90.

[138] Peek ME, Odoms-Young A, Quinn MT, Gorawara-Bhat R, Wilson SC, Chin MH. Race and shared decision-making: perspectives of African-Americans with diabetes. Soc Sci Med 2010;71:1-9.

[139] Sheppard VB, Adams IF, Lamdan R, Taylor KL. The role of patient-provider communication for black women making decisions about breast cancer treatment. Psychooncology 2011;20:1309-16.

[140] Zapka JG, Carter R, Carter CL, Hennessy W, Kurent JE, DesHarnais S. Care at the end of life: focus on communication and race. J Aging Health 2006;18:791-813.

[141] Chudley S, Skelton J, Wall D, Jones E. Teaching cross-cultural consultation skills: a course for UK and internationally trained general practice registrars. Educ Prim Care 2007;18:602-15. 
Paternotte, E., Dulmen, S. van, Lee, N. van der, Scherpbier, A.J.J.A., Scheele, F. Factors influepæing intercultural doctor-patient communication: a realist review. Patient Education and Counseling: 2015, 98(4), 420-445

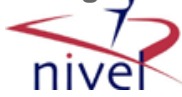

[142] Rodriguez MA, Bauer HM, Flores-Ortiz Y, Szkupinski-Quiroga S. Factors affecting patientphysician communication for abused Latina and Asian immigrant women. J Fam Pract 1998;47:30911.

[143] Cene CW, Roter D, Carson KA, Miller III ER, Cooper LA. The effect of patient race and blood pressure control on patient-physician communication. J Gen Intern Med 2009;24:1057-64.

[144] De MS, Deveugele M, Willems S. Language, culture and emotions: exploring ethnic minority patients' emotional expressions in primary healthcare con-sultations. Patient Educ Couns 2011;84:406-12.

[145] Gerlach H, Becker N, Abholz HH. Experience of German general practitioners with patients having a migration background-results of a focus group. Z Allg med 2008;84:428-35.

[146] Ghods BK, Roter DL, Ford DE, Larson S, Arbelaez JJ, Cooper LA. Patient- physician communication in the primary care visits of African Americans and whites with depression. J Gen Intern Med 2008;23:600-6.

[147] Neal RD, Ali N, Atkin K, Allgar VL, Ali S, Coleman T. Communication between South Asian patients and GPs: comparative study using the Roter interaction analysis system. Br J Gen Pract 2006;56:869-75.

[148] Rivadeneyra R, Elderkin-Thompson V, Silver RC, Waitzkin H. Patient centeredness in medical encounters requiring an interpreter. Am J Med 2000;108:470-4.

[149] Shapiro J, Saltzer E. Cross-cultural aspects of physician-patient communica-tions patterns. Urban Health 1981;10:10-5.

[150] Barkin S, Balkrishnan R, Manuel J, Hall MA. Effect of language immersion on communication with Latino patients. N C Med J 2003;64:258-62.

[151] Towle A, Godolphin W, Alexander T. Doctor-patient communications in the Aboriginal community: towards the development of educational programs. Patient Educ Couns 2006;62:340-6.

[152] Wallace LS, DeVoe JE, Rogers ES, Malagon-Rogers M, Fryer Jr GE. The medical dialogue: disentangling differences between Hispanic and non-Hispanic whites. J Gen Intern Med 2007;22:1538-43.

[153] Browner CH, Preloran HM, Casado MC, Bass HN, Walker AP. Genetic counsel-ing gone awry: miscommunication between prenatal genetic service provi-ders and Mexican-origin clients. Soc Sci Med 2003;56:1933-46.

[154] Butow P, Bell M, Goldstein D, Sze M, Aldridge L, Abdo S, et al. Grappling with cultural differences; communication between oncologists and immigrant cancer patients with and without interpreters. Patient Educ Couns 2011;84:398-405.

[155] Simon CM, Kodish ED. Step into my zapatos, Doc: understanding and reducing communication disparities in the multicultural informed consent setting. Perspect Biol Med 2005;48:S123-38.

[156] Mitchison D, Butow P, Sze M, Aldridge L, Hui R, Vardy J, et al. Prognostic communication preferences of migrant patients and their relatives. Psy-chooncology 2012;21:496-504.

[157] Ali N, Atkin K, Neal R. The role of culture in the general practice consultation process. Ethn Health 2006;11:389-408.

[158] Bullock K. The influence of culture on end-of-life decision making. J Soc Work End Life Palliat Care 2011;7:83-98.

[159] Hoang HT, Le Q, Kilpatrick S. Having a baby in the new land: a qualitative exploration of the experiences of Asian migrants in rural Tasmania, Australia. Rural Remote Health 2009;9:1084.

[160] Mack JW, Paulk ME, Viswanath K, Prigerson HG. Racial disparities in the outcomes of communication on medical care received near death. Arch Intern Med 2010;170:1533-40.

[161] Wilson M, MacCarthy B. GP consultation as a factor in the low rate of mental health service use by Asians. Psychol Med 1994;24:113-9.

[162] Lingard L, Tallett S, Rosenfield J. Culture and physician-patient communica-tion: a qualitative exploration of residents' experiences and attitudes. Ann R Coll Phys Surg Can 2002;35:331-5.

[163] Shapiro J, Hollingshead J, Morrison E. Self-perceived attitudes and skills of cultural competence: a comparison of family medicine and internal medicine residents. Med Teach 2003;25:327-9.

[164] Williams SW, Hanson LC, Boyd C, Green M, Goldmon M, Wright G, et al. Communication, decision making, and cancer: what African Americans want physicians to know. J Palliat Med 2008;11:1221-6.

[165] Ameresekere M, Borg R, Frederick J, Vragovic O, Saia K, Raj A. Somali immigrant women's perceptions of cesarean delivery and patient-provider communication surrounding female circumcision and childbirth in the USA. Int J Gynaecol Obstet 2011;115:227-30. 
Paternotte, E., Dulmen, S. van, Lee, N. van der, Scherpbier, A.J.J.A., Scheele, F. Factors influepæing intercultural doctor-patient communication: a realist review. Patient Education and Counseling: 2015, 98(4), 420-445

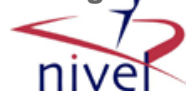

[166] Simonds VW, Christopher S, Sequist TD, Colditz GA, Rudd RE. Exploring patient-provider interactions in a Native American community. J Health Care Poor Underserved 2011;22:836-52. [167] Cooper LA, Roter DL, Johnson RL, Ford DE, Steinwachs DM, Powe NR. Patient-centered communication, ratings of care, and concordance of patient and physician race. Ann Intern Med 2003;139:907-15.

[168] Mutchler JE, Bacigalupe G, Coppin A, Gottlieb A. Language barriers sur- rounding medication use among older Latinos. J Cross Cult Gerontol 2007;22:101-14.

[169] Weinick RM, Elliott MN, Volandes AE, Lopez L, Burkhart Q, Schlesinger M. Using standardized encounters to understand reported racial/ethnic dispar-ities in patient experiences with care. Health Serv Res 2011;46:491-509.

[170] de $\mathrm{HH}$, Bensing J. Endpoints in medical communication research, proposing a framework of functions and outcomes. Patient Educ Couns 2009;74:287-94.

[171] Mead N, Bower P. Patient-centredness: a conceptual framework and review of the empirical literature. Soc Sci Med 2000;51:1087-110.

[172] Arasaratnam LA, Doerfel ML. Intercultural communication competence: identifying key components from multicultural perspectives. Int J Interc Relat 2005;29:137-63.

[173] Kim YY. Cross-cultural interpersonal communication. In: Ting-Tommey S, FKE, editors. Intercultral communication competence: a system-theoretical view. Newbury Park, CA: Sage; 1991. p. 259-75.

[174] Kurtz S, Silverman J, Draper J. Teaching and learning communication skills in medicine. 1998 ed. Oxford: Oxford Radcliffe Medical Press; 1998.

\section{TABLES}

of the used terminology.

\begin{tabular}{|c|c|}
\hline $\mathrm{y}^{*}$ & Explanation \\
\hline & $\begin{array}{l}\text { Culture is a socially transmitted pattern of shared meanings by which people communicate, perpetuate and } \\
\text { develop their knowledge and attitudes about life. An individual's cultural identity may be based on heritage } \\
\text { as well as individual circumstances and personal choice and is a dynamic entity [23] }\end{array}$ \\
\hline l diversity & The diversity of people with different ethnic cultural and linguistic backgrounds [24] \\
\hline round & $\begin{array}{l}\text { The fact or state of belonging to a social group that has a common national or cultural tradition: 'the } \\
\text { interrelationship between gender, ethnicity, and class' [25] }\end{array}$ \\
\hline petence & Knowledge, attitudes and skills required to provide good quality care to ethnically diverse patient populations [26] \\
\hline 1 communication & $\begin{array}{l}\text { Communication between doctors and patients with different ethnic backgrounds; a part of cultural } \\
\text { competence }[26,27]\end{array}$ \\
\hline communication & Comparison of communication across cultures [27] \\
\hline communication competence & The degree to which we actively monitor how we communicate with people from other ethnic cultures [28] \\
\hline petent communication & Communication repertoire, situational awareness, adaptability and knowledge about core cultural issues [9] \\
\hline l sensitivity & $\begin{array}{l}\text { The degree to which we are actively interested in other people's cultural backgrounds, their needs and } \\
\text { perspectives [28] }\end{array}$ \\
\hline
\end{tabular}

e explains the terminology used in our research. We are aware that this is one of the many operationalization's for these terms. 
Paternotte, E., Dulmen, S. van, Lee, N. van der, Scherpbier, A.J.J.A., Scheele, F. Factors influepring intercultural doctor-patient communication: a realist review. Patient Education and Counseling: 2015, 98(4), 420-445

\section{Table 2}

Inclusion criteria.

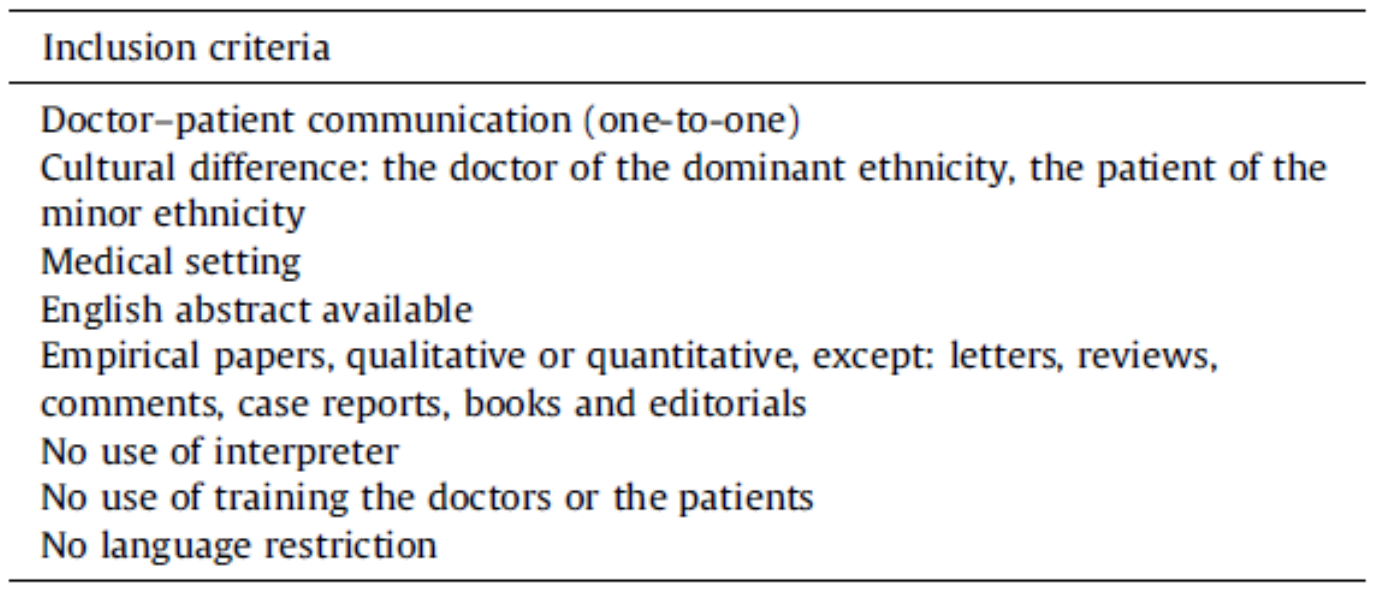

Fig. 1. Flowchart of the included articles. E. Paternotte et al. / Patient Education and Counseling 98 (2015) 420-445 423 
Paternotte, E., Dulmen, S. van, Lee, N. van der, Scherpbier, A.J.J.A., Scheele, F. Factors influepæing intercultural doctor-patient communication: a realist review. Patient Education and Counseling: 2015, 98(4), 420-445

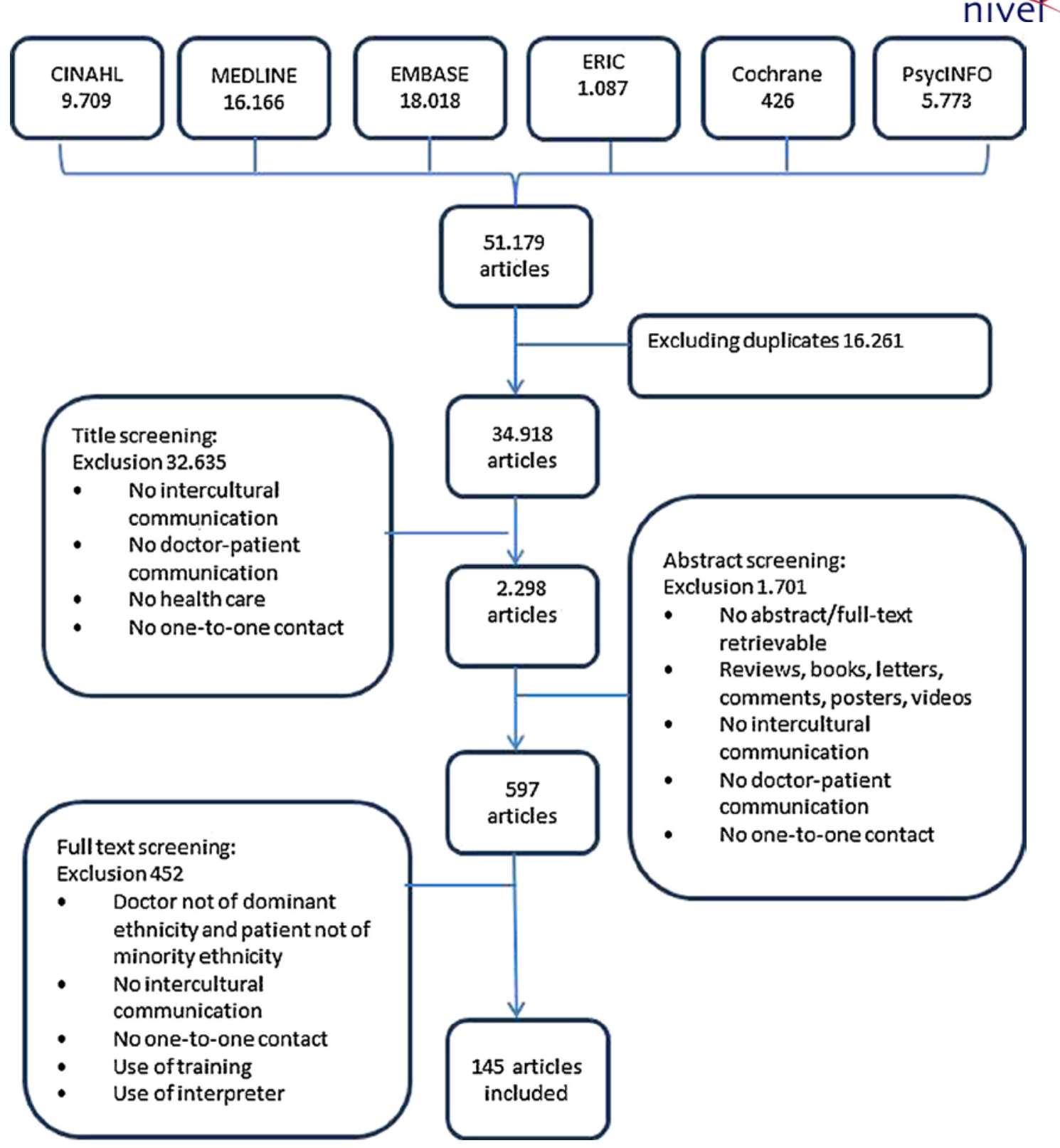

Fig. 2. Context-mechanism-outcome framework for Intercultural communication.
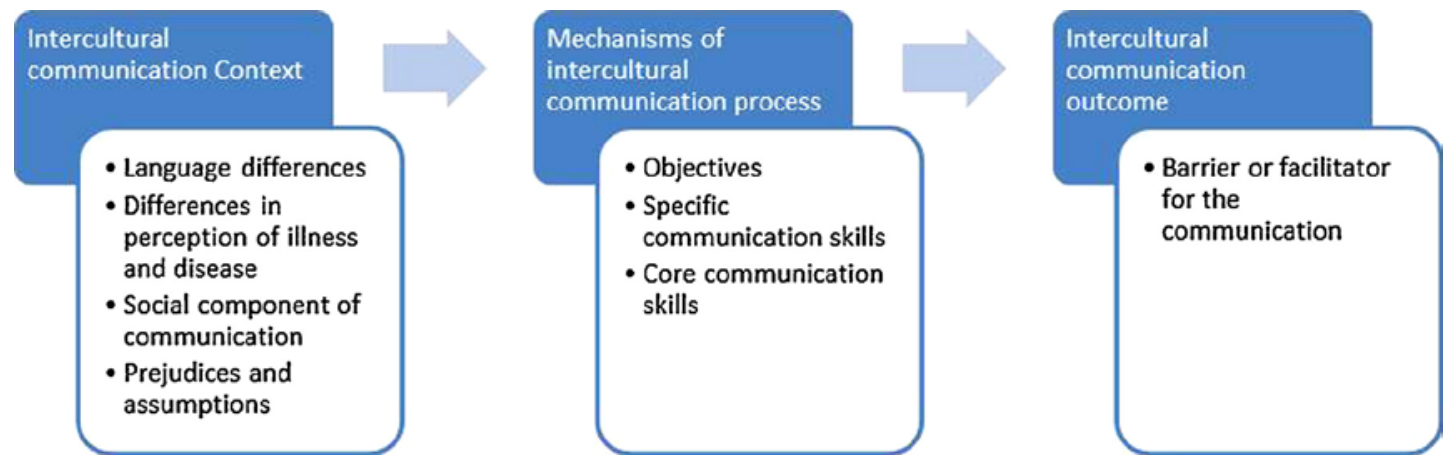
Paternotte, E., Dulmen, S. van, Lee, N. van der, Scherpbier, A.J.J.A., Scheele, F. Factors influepæing intercultural doctor-patient communication: a realist review. Patient Education and Counseling: 2015, 98(4), 420-445

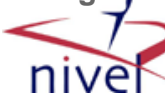

texts with the mechanisms of the communication process to facilitate the intercultural communication; summary of the results.

Iral communication contexts $\rightarrow$ Mechanisms of the process of intercultural communication $\rightarrow$ Communication outcomes

\begin{tabular}{|c|c|c|c|c|}
\hline ion & Objectives & Specific skills & Core skills & $\begin{array}{l}\text { Communication } \\
\text { outcome }\end{array}$ \\
\hline & $\begin{array}{l}\text {-Knowledge of languages } \\
\text {-Understanding the patient }\end{array}$ & $\begin{array}{l}\text {-Being able to speak a few words in } \\
\text { the patient's language } \\
\text {-Recognizing misunderstandings } \\
\text { caused by language differences } \\
\text {-Using attributes for explanation } \\
\text { (pictures, interpreter) } \\
\text {-Paying attention to pronunciation } \\
\text {-Using various ways of providing } \\
\text { explanations }\end{array}$ & $\begin{array}{l}\text {-Giving information in pieces } \\
\text {-Checking if the patient understood } \\
\text {-Active listening } \\
\text {-Sharing decision making } \\
\text {-Avoiding unnecessary medical } \\
\text { jargon } \\
\text {-Adapting the explanation to the } \\
\text { patient } \\
\text {-Paraphrasing and repeating the } \\
\text { patient's exact words }\end{array}$ & $\begin{array}{l}\text { Barrier or facilitator for } \\
\text { effective } \\
\text { communication about } \\
\text { substantive } \\
\text { health care issues }\end{array}$ \\
\hline $\begin{array}{l}\text { of } \\
\text { disease }\end{array}$ & $\begin{array}{l}\text {-Knowledge of cultural differences } \\
\text {-Awareness of cultural differences } \\
\text { (different paradigms) } \\
\text {-Expectation management } \\
\text { regarding the health care system } \\
\text {-Mutual understanding } \\
\text {-Respect } \\
\text {-Patient-centered communication } \\
\text { (shared decision making) }\end{array}$ & $\begin{array}{l}\text {-Recognizing misunderstandings } \\
\text { caused by cultural differences } \\
\text {-Recognizing the patient's } \\
\text { expectations of the health system } \\
\text {-Awareness of one's own culture }\end{array}$ & $\begin{array}{l}\text {-Respecting the patient's habits, } \\
\text { norms and values } \\
\text {-Becoming familiar with the } \\
\text { situation and context of the patient } \\
\text {-Understanding the patient } \\
\text { (empathic communication) } \\
\text {-Informing the patient about the } \\
\text { medical procedures/system } \\
\text {-Having an open attitude } \\
\text {-Explaining } \\
\text {-Time management } \\
\text {-Active listening } \\
\text {-Demonstrating trustworthiness } \\
\text {-Handling emotions }\end{array}$ & \\
\hline $\begin{array}{l}\text { ient } \\
\text { ication }\end{array}$ & $\begin{array}{l}\text {-Knowledge of position of relatives } \\
\text {-Awareness of the role of relatives } \\
\text { for the patient }\end{array}$ & $\begin{array}{l}\text {-Knowing the relatives of the patient } \\
\text {-Showing interest in the relatives }\end{array}$ & $\begin{array}{l}\text {-Relation building with family and } \\
\text { patient } \\
\text {-Handling emotions }\end{array}$ & \\
\hline & $\begin{array}{l}\text {-Knowledge of cultural differences } \\
\text {-Awareness of cultural differences }\end{array}$ & $\begin{array}{l}\text {-Awareness of one's assumptions } \\
\text { regarding cultural differences } \\
\text {-Dealing with a patient's negative } \\
\text { previous experiences }\end{array}$ & $\begin{array}{l}\text {-Learning from previous } \\
\text { experiences } \\
\text {-Open attitude } \\
\text {-Handling emotions } \\
\text {-Showing respect } \\
\text {-Demonstrating trustworthiness }\end{array}$ & \\
\hline
\end{tabular}

APPENDIX A. EXAMPLE OF SEARCH STRING

\begin{tabular}{|c|c|}
\hline \begin{tabular}{|c|} 
Search string \\
MEDLINE \\
\end{tabular} & \\
\hline$\# 1$ & $\begin{array}{l}\text { Language*[tiab] OR communicati*[tiab] OR Communication[Mesh] OR } \\
\text { “Professional-Patient Relations”[Mesh] OR contacting client*[tiab] OR } \\
\text { medical consult*[tiab] }\end{array}$ \\
\hline$\# 2$ & $\begin{array}{l}\text { “Internship and Residency”[Mesh] OR physician*[tiab] OR nurse*[tiab] OR } \\
\text { doctor*[tiab] OR professional*[tiab] OR gp[tiab] OR gps[tiab] OR } \\
\text { practitioner*[tiab] OR provider*[tiab] OR resident*[tiab] OR intern[tiab] OR } \\
\text { interns*[tiab] OR postgraduate*[tiab] OR post graduate*[tiab] OR house } \\
\text { officer*[tiab] OR house staff[tiab] OR registrar*[tiab] OR specialist } \\
\text { training*[tiab] OR trainee*[tiab] OR clinician*[tiab] OR attending*[tiab] OR } \\
\text { consultant*[tiab] OR medical specialist*[tiab] }\end{array}$ \\
\hline$\# 3$ & Patient[tiab] OR patients[tiab] OR client*[tiab] OR health consumer*[tiab] \\
\hline
\end{tabular}


Paternotte, E., Dulmen, S. van, Lee, N. van der, Scherpbier, A.J.J.A., Scheele, F. Factors influepeing intercultural doctor-patient communication: a realist review. Patient Education and Counseling: 2015, 98(4), 420-445

\begin{tabular}{|c|c|}
\hline \begin{tabular}{|c|} 
Search string \\
MEDLINE \\
\end{tabular} & \\
\hline$\# 4$ & $\begin{array}{l}\text { Relation*[tiab] OR interaction*[tiab] OR interview*[tiab] OR } \\
\text { communicati*[tiab] }\end{array}$ \\
\hline$\# 5$ & $((\# 2)$ AND \#3) AND \#4 \\
\hline$\# 6$ & $(\# 1)$ OR \#5 \\
\hline \#7 & $\begin{array}{l}\text { “Delivery of Health Care”[Mesh] OR “Physicians, Primary Care”[Mesh] OR } \\
\text { "Primary Care Nursing”[Mesh] OR "Primary Health Care”[Mesh] OR } \\
\text { “Hospitals”[Mesh] OR healthcare[tiab] OR health care[tiab] OR primary } \\
\text { care[tiab] OR hospital[tiab] OR hospitals[tiab] OR general practice*[tiab] OR } \\
\text { family practice*[tiab] OR secondary care[tiab] OR medical practice*[tiab] OR } \\
\text { medicin*[tiab] }\end{array}$ \\
\hline \#8 & $\begin{array}{l}\text { Cultur*[tiab] OR Crosscultural* OR Cross cultural* OR Intercultural*[tiab] } \\
\text { OR Multicultural*[tiab] OR Transcultural*[tiab] OR Interracial*[tiab] OR } \\
\text { Ethnic*[tiab] OR Diversit*[tiab] OR Migrant*[tiab] OR Immigrant*[tiab] OR } \\
\text { Minorit*[tiab] OR Race[tiab] OR Racial*[tiab] OR Emigrants and } \\
\text { Immigrants[Mesh] OR Emigration and Immigration[Mesh] OR Cultural } \\
\text { Diversity[Mesh] OR Ethnic Groups[Mesh] OR Minority Groups[Mesh] } \\
\end{array}$ \\
\hline$\# 9$ & $((\# 6)$ AND \#7) AND \#8 \\
\hline$\# 10$ & $\begin{array}{l}\text { “Review” [Publication Type] OR “Ephemera” [Publication Type] OR } \\
\text { “Comment” [Publication Type] OR “Case Reports” [Publication Type] OR } \\
\text { “"Editorial” [Publication Type] }\end{array}$ \\
\hline$\# 11$ & (\#9) NOT \#10 \\
\hline$\# 12$ & \#11 AND hasabstract \\
\hline
\end{tabular}


Paternotte, E., Dulmen, S. van, Lee, N. van der, Scherpbier, A.J.J.A., Scheele, F. Factors influencing intercultural doctor-patient communication: a realist review. Patient Education and Counseling: 2015, 98(4), 420-445

APPENDIX B. TABLE WITH ARTICLE CHARACTERISTICS OF THE INCLUDED ARTICLES, DESCRIBED BY CONTEXT (PARTICIPANTS, ETHNICITY, SETTING), MECHANISM AND OUTCOME (RESULTS)

\begin{tabular}{|c|c|c|c|c|c|c|c|c|c|}
\hline $\begin{array}{c}\text { Author } \\
\text { year }\end{array}$ & $\begin{array}{c}\text { Languag } \\
\text { e }\end{array}$ & $\begin{array}{c}\text { Design \& } \\
\text { Method }\end{array}$ & Participants & Theory & $\begin{array}{c}\text { Ethnicity } \\
\text { patient }\end{array}$ & $\begin{array}{l}\text { Setting, } \\
\text { country }\end{array}$ & Results & $\begin{array}{l}\text { Frame of } \\
\text { reference }\end{array}$ & $\mid \begin{array}{c}\text { Level of } \\
\text { contributi } \\
\text { on }^{1,2, *}\end{array}$ \\
\hline $\begin{array}{l}\text { Sheets et } \\
\text { al., } 2012\end{array}$ & English & $\begin{array}{l}\text { Qualitativ } \\
\text { e, } \\
\text { interview }\end{array}$ & 14 Mothers & None & \begin{tabular}{||l} 
Spanish \\
speaking \\
Latina's
\end{tabular} & $\begin{array}{l}\text { Down } \\
\text { syndrome } \\
\text {, US }\end{array}$ & \begin{tabular}{|l|} 
The mothers desired the news in a more positive, \\
balanced light and with more complete \\
explanations(less medical jargon, less scientific \\
description, slower pace). Participants used religious \\
beliefs to explain the reason for the condition
\end{tabular} & Patient & High $(+/+)$ \\
\hline \begin{tabular}{|l||} 
August \\
et al., \\
2011
\end{tabular} & English & $\begin{array}{l}\text { Mixed, } \\
\text { interview }\end{array}$ & |2960 Adults & None & \begin{tabular}{|l} 
Latino, vs \\
Asian \\
Pacific
\end{tabular} & \begin{tabular}{|l} 
Mental \\
health, \\
US
\end{tabular} & $\begin{array}{l}\text { There were no significant differences between } \\
\text { language-discordance and English language- } \\
\text { concordant older adults in predicting discussion on } \\
\text { mental health concerns }\end{array}$ & Patient & $\mid \begin{array}{l}\text { Medium } \\
(-/+)\end{array}$ \\
\hline $\begin{array}{l}\text { Watt et } \\
\text { al., } 2011\end{array}$ & English & $\begin{array}{l}\text { Qualitativ } \\
\text { e, } \\
\text { grounded } \\
\text { theory, } \\
\text { interview }\end{array}$ & |50 Parents & None & \begin{tabular}{||l} 
Chinese \\
and south \\
Asian
\end{tabular} & $\begin{array}{l}\text { Oncology } \\
\text {, Canada }\end{array}$ & $\begin{array}{l}\text { Parents were highly satisfied with the care, but not } \\
\text { comfort with that providers communicated sensitive } \\
\text { health issues directly to the child. Part of } \\
\text { communication is understanding of the dr }\end{array}$ & Patient & Low $(-/-)$ \\
\hline $\begin{array}{l}\text { Amerese } \\
\text { kere et } \\
\text { al., } 2011\end{array}$ & English & $\begin{array}{l}\text { Qualitativ } \\
\text { e, } \\
\text { interview }\end{array}$ & 23 Patients & None & $\mid \begin{array}{l}\text { Somali } \\
\text { women }\end{array}$ & US & $\begin{array}{l}\text { Experiences and cultural beliefs of pts influenced } \\
\text { thoughts of pts about health care. Misperception } \\
\text { causes fear. Pts want a clear explanation of the } \\
\text { procedure. Pts had little personal knowledge and } \\
\text { limited discussion with drs }\end{array}$ & Patient & $\mid \begin{array}{l}\text { Medium } \\
(-/+)\end{array}$ \\
\hline $\begin{array}{l}\text { Villagran } \\
\text { et al., }\end{array}$ & English & $\begin{array}{l}\text { Quantitati } \\
\text { ve, }\end{array}$ & 217 Patients & $\begin{array}{l}\text { Burgoon } \\
1996+\text { Ha }\end{array}$ & Mexican & US & $\begin{array}{l}\text { Culture plays a fundamental role in healthcare } \\
\text { interactions. Mexican immigrant pts desired } \\
\text { linguistic accommodation from drs. Cultural identity }\end{array}$ & Patient & High $(+/+)$ \\
\hline
\end{tabular}

This is a NIVEL certified Post Print, more info at http://www.nivel.eu 
Paternotte, E., Dulmen, S. van, Lee, N. van der, Scherpbier, A.J.J.A., Scheele, F. Factors influencing intercultural doctor-patient communication: a realist

\begin{tabular}{|c|c|c|c|c|c|c|c|c|c|}
\hline $\begin{array}{c}\text { Author } \\
\text { year }\end{array}$ & $\begin{array}{c}\text { Languag } \\
\mathbf{e}\end{array}$ & $\begin{array}{l}\text { Design \& } \\
\text { Method }\end{array}$ & Participants & Theory & $\begin{array}{c}\text { Ethnicity } \\
\text { patient }\end{array}$ & $\begin{array}{l}\text { Setting, } \\
\text { country }\end{array}$ & Results & $\begin{array}{l}\text { Frame of } \\
\text { reference }\end{array}$ & $\mid \begin{array}{c}\text { Level of } \\
\text { contributi } \\
\text { on }^{1,2,-}\end{array}$ \\
\hline 2012 & & \begin{tabular}{|l} 
structural \\
equation \\
modeling \\
(survey)
\end{tabular} & & \begin{tabular}{|l|} 
rwoow and \\
Giles 2005
\end{tabular} & & & $\begin{array}{l}\text { played an important role in expectations of the } \\
\text { medical visit. Complex relation between out-group } \\
\text { perception (immigrant status) and adherence }\end{array}$ & & \\
\hline $\mid \begin{array}{l}\text { Song et } \\
\text { al., } 2011\end{array}$ & English & $\begin{array}{l}\text { Qualitativ } \\
\text { e, } \\
\text { interview, } \\
\text { grounded } \\
\text { theory }\end{array}$ & |28 Patients & None & $\begin{array}{l}\text { African } \\
\text { American }\end{array}$ & $\begin{array}{l}\text { Oncology } \\
\text {, US }\end{array}$ & \begin{tabular}{|l|} 
Four domains: pts want open communication of \\
cancer info, experience lack of shared decision \\
making, empathy and understanding, respect. Not \\
knowing what questions to ask and not \\
understanding contributed to limited discussion. \\
Facilitator: dr who attentively listened, provide \\
encouragement, demonstrating non-verbal behaviors \\
of caring. Barriers: dr uses inappropriate language, \\
no time, pt experience discrimination
\end{tabular} & Patient & High $(+/+)$ \\
\hline $\begin{array}{l}\text { Simonds } \\
\text { et al., } \\
2011\end{array}$ & English & $\begin{array}{l}\text { Quantitati } \\
\text { ve, } \\
\text { interview, } \\
\text { critical } \\
\text { incidence }\end{array}$ & \begin{tabular}{|l}
35 Patients, \\
16 providers \\
(presumably \\
dr)
\end{tabular} & $\begin{array}{l}\text { Roter and } \\
\text { Hall 1987, } \\
\text { Betancourt } \\
2003\end{array}$ & \begin{tabular}{|l} 
American \\
Native \\
(minor)- \\
non-Native
\end{tabular} & $\begin{array}{l}\text { Gynaecol } \\
\text { ogie, US }\end{array}$ & \begin{tabular}{|l} 
Trust is central in dr-pt communication, influenced \\
by context, expectations, history and time. Barrier: \\
expecting pts to discuss important things right \\
away $(\mathrm{dr})$, lack of continuity of care $(\mathrm{dr}+\mathrm{pt})$ \\
waiting time $(\mathrm{dr}+\mathrm{pt})$, visit context(reason and \\
situation), stories (pt) \\
Facilitator: visit context (reason and situation), extra \\
time (dr), receiving advice and educational \\
information (pt), concern of dr (pt)
\end{tabular} & $\begin{array}{l}\text { Patient }+ \text { doct } \\
\text { or }\end{array}$ & High $(+/+)$ \\
\hline $\begin{array}{l}\text { Maessch } \\
\text { alck et } \\
\text { al., } 2012\end{array}$ & English & $\begin{array}{l}\text { Quantitati } \\
\text { ve, } \\
\text { Interview }\end{array}$ & \begin{tabular}{||}
191 video's, \\
77 doctors
\end{tabular} & None & Mixed & \begin{tabular}{|l} 
Primary \\
care, \\
Belgium
\end{tabular} & \begin{tabular}{|l} 
Language problems or pure biomedical \\
consultations resulted into less emotional cues. Pts' \\
language proficiency had a more important impact \\
on the number of cues expressed by the pt than
\end{tabular} & Observer & High $(+/+)$ \\
\hline
\end{tabular}


Paternotte, E., Dulmen, S. van, Lee, N. van der, Scherpbier, A.J.J.A., Scheele, F. Factors influencing intercultural doctor-patient communication: a realist

\begin{tabular}{|c|c|c|c|c|c|c|c|c|c|}
\hline $\begin{array}{c}\text { Author } \\
\text { year }\end{array}$ & $\begin{array}{c}\text { Languag } \\
\mathbf{e}\end{array}$ & $\mid \begin{array}{c}\text { Design \& } \\
\text { Method }\end{array}$ & Participants & Theory & $\begin{array}{c}\text { Ethnicity } \\
\text { patient }\end{array}$ & $\begin{array}{l}\text { Setting, } \\
\text { country }\end{array}$ & Results & $\begin{array}{l}\text { Frame of } \\
\text { reference }\end{array}$ & $\begin{array}{c}\text { Level of } \\
\text { contributi } \\
\text { on }^{1,2, *}\end{array}$ \\
\hline & & + video & & & & & $\begin{array}{l}\text { cultural difference. Barriers: language and } \\
\text { acculturation }\end{array}$ & & \\
\hline $\begin{array}{l}\text { Gurnah } \\
\text { et al., } \\
2011\end{array}$ & English & \begin{tabular}{|l} 
Qualitativ \\
e, \\
interview, \\
focus \\
group, \\
questionna \\
ire
\end{tabular} & ||39 women & None & $\begin{array}{l}\text { Somali } \\
\text { Bantu }\end{array}$ & $\begin{array}{l}\text { Reproduc } \\
\text { tive } \\
\text { health, } \\
\text { US }\end{array}$ & $\begin{array}{l}\text { Barriers to healthcare and good communication are } \\
\text { miscommunication (language), mistranslation and } \\
\text { lack of self-advocacy, lack of cultural fluency } \\
\text { (understanding the deeply entrenched attitudes, } \\
\text { behavior) }\end{array}$ & Patient & $\begin{array}{l}\text { Medium }(- \\
/+)\end{array}$ \\
\hline $\begin{array}{l}\text { Kale et } \\
\text { al., } 2011\end{array}$ & English & \begin{tabular}{|l} 
Quantitati \\
ve, \\
observatio \\
n
\end{tabular} & $\mid \begin{array}{l}56 \\
\text { Consultations/ } \\
\text { patients, } 26 \\
\text { doctors }\end{array}$ & None & $\begin{array}{l}\text { Immigrants } \\
\text { vs } \\
\text { Norwegian } \\
\text { patients }\end{array}$ & Norway & $\begin{array}{l}\text { Immigrant pts without language problems expressed } \\
\text { more worries than with language problems and } \\
\text { Norwegian pts. No differences in emotional cues } \\
\text { between immigrant pt and Norwegian. Barriers: } \\
\text { language proficiency of pt }\end{array}$ & Observer & $\operatorname{High}(+/+)$ \\
\hline $\begin{array}{l}\text { Quinn et } \\
\text { al., } 2011\end{array}$ & English & $\begin{array}{l}\text { Qualitativ } \\
\text { e, } \\
\text { questionna } \\
\text { ire }\end{array}$ & $\mid \begin{array}{l}91 \text { Patients, } \\
72 \text { oncologist }\end{array}$ & None & $\begin{array}{l}\text { Spanish } \\
\text { speaking }\end{array}$ & $\begin{array}{l}\text { Oncology } \\
\text {, US }\end{array}$ & $\begin{array}{l}\text { Pts felt knowing less and it is important to be able to } \\
\text { communicate in their preferred language with their } \\
\text { dr. Drs want to be more informed of communication } \\
\text { difficulties }\end{array}$ & $\begin{array}{l}\text { Patient }+ \text { doct } \\
\text { or }\end{array}$ & $\operatorname{Low}(-/-)$ \\
\hline $\begin{array}{l}\text { Hausman } \\
\text { n et al., } \\
2011\end{array}$ & English & $\mid \begin{array}{l}\text { Quantitati } \\
\text { ve, } \\
\text { audiotapes }\end{array}$ & $\mid$\begin{tabular}{||l}
353 Patients, \\
63 orthopedic \\
surgeons
\end{tabular} & None & $\begin{array}{l}\text { African } \\
\text { American } \\
\text { vs White }\end{array}$ & $\begin{array}{l}\text { Orthopedi } \\
\text { cs, US }\end{array}$ & $\begin{array}{l}\text { Perceptions of past racism in healthcare may } \\
\text { negatively impact the affective tone of pt-dr } \\
\text { communication. Barriers: experience of } \\
\text { discrimination } \rightarrow \text { less positive nonverbal affect, less } \\
\text { dr warmth, less ease of communication }\end{array}$ & $\begin{array}{l}\text { Patient + obs } \\
\text { erver }\end{array}$ & $\begin{array}{l}\text { Medium }(- \\
/+)\end{array}$ \\
\hline Degni et & English & Qualitativ & 10 Doctors & None & Somalia & gynecolo & Cultural differences cause communication problems. & Doctor & Medium \\
\hline
\end{tabular}


Paternotte, E., Dulmen, S. van, Lee, N. van der, Scherpbier, A.J.J.A., Scheele, F. Factors influencing intercultural doctor-patient communication: a realist

\begin{tabular}{|c|c|c|c|c|c|c|c|c|c|}
\hline $\begin{array}{c}\text { Author } \\
\text { year }\end{array}$ & $\begin{array}{c}\text { Languag } \\
\text { e }\end{array}$ & $\begin{array}{c}\text { Design \& } \\
\text { Method }\end{array}$ & Participants & Theory & $\begin{array}{c}\text { Ethnicity } \\
\text { patient }\end{array}$ & $\begin{array}{l}\text { Setting, } \\
\text { country }\end{array}$ & Results & $\begin{array}{l}\text { Frame of } \\
\text { reference }\end{array}$ & $\begin{array}{c}\text { Level of } \\
\text { contributi } \\
\text { on }^{1,2,-*}\end{array}$ \\
\hline al., 2012 & & \begin{tabular}{|l|} 
e, focus \\
groups, \\
interviews
\end{tabular} & & & patients & \begin{tabular}{|l|} 
gy, \\
Finland
\end{tabular} & $\begin{array}{l}\text { Cultural traditions and beliefs were unfamiliar to } \\
\text { drs. Drs are not able to communicate directly to } \\
\text { several Somali women. Drs have no time to } \\
\text { socialize. Barrier: inactive role of the dr }\end{array}$ & & $(-/+)$ \\
\hline $\begin{array}{l}\text { Horn et } \\
\text { al., } 2011\end{array}$ & English & 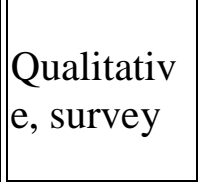 & 425 Parents & None & $\begin{array}{l}\text { African } \\
\text { American }\end{array}$ & $\begin{array}{l}\text { Pediatrics } \\
\text {, US }\end{array}$ & $\begin{array}{l}\text { Most pts perceived that the dr used moderate/high } \\
\text { partnership-building communication. Concordance } \\
\text { of dr-pt does not play a significant role in pt } \\
\text { perception of partnership in the relation with the } \mathrm{dr}\end{array}$ & Patient & Low $(-/-)$ \\
\hline $\begin{array}{l}\text { Bullock, } \\
2011\end{array}$ & English & \begin{tabular}{|l|} 
Qualitativ \\
e, \\
interview \\
+ focus \\
group
\end{tabular} & |202 adults & \begin{tabular}{|l|} 
Johnson, \\
Kuchibhatl \\
a and \\
Tulsky \\
2008 \\
\end{tabular} & $\begin{array}{l}\text { Black vs } \\
\text { White }\end{array}$ & $\begin{array}{l}\text { End-of- } \\
\text { life care, } \\
\text { US }\end{array}$ & \begin{tabular}{|l} 
Black pts expressed feeling of mistrust and lack of \\
positive relationship with a 'regular' dr. Black pt \\
wants the family to be part of the decision. Black pts \\
have more negative experiences. Black pts talk more \\
about their belief in miracles
\end{tabular} & Patient & $\mid \begin{array}{l}\text { Medium } \\
(-/+)\end{array}$ \\
\hline $\begin{array}{l}\text { Butow et } \\
\text { al., } 2011\end{array}$ & English & \begin{tabular}{|l} 
Quantitati \\
ve, \\
audiotapes \\
+ questio \\
nnaire
\end{tabular} & $\mid \begin{array}{l}141 \\
\text { audiotapes, } 10 \\
\text { oncologist, } 15 \\
\text { immigrants }\end{array}$ & None & $\mid \begin{array}{l}\text { Immigrants } \\
\text { vs Anglo- } \\
\text { Australian }\end{array}$ & Oncology & $\begin{array}{l}\text { Drs spoke less to immigrants, spent less time to } \\
\text { cancer related issues, summarizing and informing, } \\
\text { but more time to other medical issues and advising. } \\
\text { Drs tented to delay responses to or ignore more } \\
\text { immigrant than Anglo-Australian cues }\end{array}$ & Observer & $\mid \begin{array}{l}\text { Medium } \\
(-/+)\end{array}$ \\
\hline $\begin{array}{l}\text { Gulati et } \\
\text { al., } 2012\end{array}$ & English & $\begin{array}{l}\text { Qualitativ } \\
\text { e, } \\
\text { interviews } \\
\text {, grounded } \\
\text { theory }\end{array}$ & 50 Patients & None & | & $\begin{array}{l}\text { Pediatric } \\
\text { oncology, } \\
\text { Canada }\end{array}$ & $\begin{array}{l}\text { Communication challenges influenced parents' role } \\
\text { in caring for their child and made it difficult to learn } \\
\text { complex medical terminology. The ability to } \\
\text { communicate effectively (non) verbally played an } \\
\text { important role in immigrants health care } \\
\text { experiences. Social aspects are important in } \\
\text { communication }\end{array}$ & Patient & $\operatorname{High}(+/+)$ \\
\hline
\end{tabular}


Paternotte, E., Dulmen, S. van, Lee, N. van der, Scherpbier, A.J.J.A., Scheele, F. Factors influencing intercultural doctor-patient communication: a realist

\begin{tabular}{|c|c|c|c|c|c|c|c|c|c|}
\hline $\begin{array}{c}\text { Author } \\
\text { year }\end{array}$ & $\begin{array}{c}\text { Languag } \\
\text { e }\end{array}$ & $\mid \begin{array}{c}\text { Design \& } \\
\text { Method }\end{array}$ & Participants & Theory & $\begin{array}{c}\text { Ethnicity } \\
\text { patient }\end{array}$ & $\begin{array}{l}\text { Setting, } \\
\text { country }\end{array}$ & Results & $\begin{array}{l}\text { Frame of } \\
\text { reference }\end{array}$ & $\mid \begin{array}{c}\text { Level of } \\
\text { contributi } \\
\text { on }^{1,2, *}\end{array}$ \\
\hline $\begin{array}{l}\text { Mitchiso } \\
\text { n et al., } \\
2012\end{array}$ & English & $\begin{array}{l}\text { Qualitativ } \\
\text { e, } \\
\text { interview }\end{array}$ & 73 Patients & None & Mixed & Oncology & \begin{tabular}{|l|} 
Pts preferred prognostic info to be delivered in a \\
caring and personalized manner from an \\
authoritative dr. Some family members wanted to \\
speak to the dr first to direct the info to the pt. Most \\
pts want open communication about their prognosis \\
in a positive way
\end{tabular} & Patient & $\operatorname{High}(+/+)$ \\
\hline $\begin{array}{l}\text { Wilkins } \\
\text { et al., } \\
2011\end{array}$ & English & $\mid \begin{array}{l}\text { Quantitati } \\
\text { ve, survey }\end{array}$ & $\mid \begin{array}{l}111,139 \\
\text { Parents }\end{array}$ & None & Mixed & $\begin{array}{l}\text { Pediatrics } \\
\text {, US }\end{array}$ & \begin{tabular}{|l|} 
Experiences with dr communication were the \\
strongest predictor rating a dr and healthcare poorly. \\
Bad communication caused negative experiences. \\
Facilitator: dr with respect, time, listening and \\
explaining skills
\end{tabular} & Patient & $\mid \begin{array}{l}\text { Medium } \\
(-/+)\end{array}$ \\
\hline $\mid \begin{array}{l}\text { Scholl et } \\
\text { al., } 2011\end{array}$ & English & $\begin{array}{l}\text { Qualitativ } \\
\text { e, } \\
\text { questionna } \\
\text { ire }\end{array}$ & $\mid \begin{array}{l}50 \text { Patients, } 8 \\
\text { doctors }\end{array}$ & \begin{tabular}{l|} 
Communic \\
ation \\
Theory of \\
Identity \\
1988 \\
(Collier\& \\
Thomas) \\
\end{tabular} & Mixed & US & \begin{tabular}{|l} 
There is interplay between culture communication \\
and language. For some pts ethnicity of the dr didn't \\
matter. Pts and drs communicate their ethnic identity \\
in similar (language is the primary source of \\
difficulty) and different ways. Barriers are: accent, \\
rate of speech, perceived rudeness, frustration, lack \\
of understanding by other party
\end{tabular} & $\begin{array}{l}\text { Doctor + pati } \\
\text { ent }\end{array}$ & High $(+/+)$ \\
\hline $\begin{array}{l}\text { Suurmon } \\
\text { d et al., } \\
2011\end{array}$ & English & $\begin{array}{l}\text { Qualitativ } \\
\text { e, } \\
\text { interview }\end{array}$ & 22 Patients & None & Mixed & $\begin{array}{l}\text { The } \\
\text { Netherlan } \\
\text { ds }\end{array}$ & $\begin{array}{l}\text { Pts experience negative events exchange of } \\
\text { information, different expectations, feeling } \\
\text { mistreated (discrimination). Illness perspective of } \\
\text { pts and disease perspective of drs are different }\end{array}$ & Patient & $\operatorname{High}(+/+)$ \\
\hline $\begin{array}{l}\text { Hausman } \\
\text { n et al., } \\
2011\end{array}$ & English & $\begin{array}{l}\text { Quantitati } \\
\text { ve, } \\
\text { audiotapes }\end{array}$ & 402 Patients & None & \begin{tabular}{|l} 
African \\
American \\
vs white
\end{tabular} & $\begin{array}{l}\text { Orthopedi } \\
\text { c, US }\end{array}$ & $\begin{array}{l}\text { Visit with AA pt contained less discussion of } \\
\text { biomedical topics and more rapport building } \\
\text { statements. No differences in length, discussion }\end{array}$ & Observer & $\operatorname{High}(+/+)$ \\
\hline
\end{tabular}


Paternotte, E., Dulmen, S. van, Lee, N. van der, Scherpbier, A.J.J.A., Scheele, F. Factors influencing intercultural doctor-patient communication: a realist

\begin{tabular}{|c|c|c|c|c|c|c|c|c|c|}
\hline $\begin{array}{c}\text { Author } \\
\text { year }\end{array}$ & $\begin{array}{c}\text { Languag } \\
\text { e }\end{array}$ & $\begin{array}{l}\text { Design \& } \\
\text { Method }\end{array}$ & Participants & Theory & $\begin{array}{c}\text { Ethnicity } \\
\text { patient }\end{array}$ & $\begin{array}{l}\text { Setting, } \\
\text { country }\end{array}$ & Results & $\begin{array}{l}\text { Frame of } \\
\text { reference }\end{array}$ & $\mid \begin{array}{c}\text { Level of } \\
\text { contributi } \\
\text { on }^{1,2, *}\end{array}$ \\
\hline & & \begin{tabular}{|l} 
survey, \\
medical \\
record \\
analyses
\end{tabular} & & & & & $\begin{array}{l}\text { psychosocial issues, pt activation, dr verbal } \\
\text { dominance }\end{array}$ & & \\
\hline $\begin{array}{l}\text { Singh- } \\
\text { Carlson } \\
\text { et al., } \\
2010\end{array}$ & English & $\begin{array}{l}\text { Qualitativ } \\
\text { e, } \\
\text { interview }\end{array}$ & |11 Women & None & $\begin{array}{l}\text { South- } \\
\text { Asian }\end{array}$ & $\begin{array}{l}\text { Oncology } \\
\text {, Canada }\end{array}$ & \begin{tabular}{|l} 
Influences of experiences of respect are language, \\
cultural values and beliefs, societal, individual and \\
institutional factors. Pts want to be seen as an \\
individual. Greeting is important. Ill pts preferred to \\
talk in their own language. The way drs talk opens \\
or closes the door. Most pts were positive about the \\
communication style of drs
\end{tabular} & Patient & $\mid \begin{array}{l}\text { Medium } \\
(-/+)\end{array}$ \\
\hline $\begin{array}{l}\text { Weinick } \\
\text { et al., } \\
2011\end{array}$ & English & \begin{tabular}{|l} 
Quantitati \\
ve, \\
written + \\
video \\
vignette, \\
questionna \\
ire
\end{tabular} & 567 Patients & None & $\begin{array}{l}\text { White, } \\
\text { African } \\
\text { American, } \\
\text { Latino }\end{array}$ & \begin{tabular}{|l} 
Disparity \\
care, US
\end{tabular} & \begin{tabular}{|l} 
Different ethnic groups have generally similar \\
expectations regarding drs' behaviors, with the \\
exception of extent to which they treat all pts fairly \\
regardless of race. Behavior of drs is interpreted on \\
different ways. Pts thought that some to all drs have \\
positive behaviors towards them. AA, Latino pts \\
think that they are treated unfairly in comparison \\
with white pts
\end{tabular} & Patient & $\mid \begin{array}{l}\text { Medium } \\
(-/+)\end{array}$ \\
\hline \begin{tabular}{|l|} 
Gonzále \\
x et al., \\
2010 \\
\end{tabular} & English & $\begin{array}{l}\text { Quantitati } \\
\text { ve, } \\
\text { interview }\end{array}$ & ||2921 Patients & None & Latino & US & $\begin{array}{l}\text { In pt-dr discordance Latino pts rated their health } \\
\text { care lower. Language concordance } \rightarrow \text { less confusion } \\
\text { and frustration }\end{array}$ & Patient & Low $(-/-)$ \\
\hline $\begin{array}{l}\text { Sheppard } \\
\text { et al., } \\
2011\end{array}$ & English & $\begin{array}{l}\text { Qualitativ } \\
\text { e, } \\
\text { interview }\end{array}$ & |49 women & None & Black & $\begin{array}{l}\text { Oncology } \\
\text {, US }\end{array}$ & $\begin{array}{l}\text { The pt-dr relationship was the most notable factor } \\
\text { that influenced treatment decisions. Most pts were } \\
\text { satisfied with the relationship, but their narratives }\end{array}$ & Patient & High $(+/+)$ \\
\hline
\end{tabular}


Paternotte, E., Dulmen, S. van, Lee, N. van der, Scherpbier, A.J.J.A., Scheele, F. Factors influencing intercultural doctor-patient communication: a realist

\begin{tabular}{|c|c|c|c|c|c|c|c|c|c|}
\hline $\begin{array}{c}\text { Author } \\
\text { year }\end{array}$ & $\begin{array}{c}\text { Languag } \\
\text { e }\end{array}$ & $\begin{array}{c}\text { Design \& } \\
\text { Method }\end{array}$ & Participants & Theory & $\begin{array}{c}\text { Ethnicity } \\
\text { patient }\end{array}$ & $\begin{array}{l}\text { Setting, } \\
\text { country }\end{array}$ & Results & $\begin{array}{l}\text { Frame of } \\
\text { reference }\end{array}$ & $\mid \begin{array}{c}\text { Level of } \\
\text { contributi } \\
\text { on }^{1,2, *}\end{array}$ \\
\hline & & & & & & & $\begin{array}{l}\text { were not. Communication with the dr was described } \\
\text { as good. Not all pts want to be completely informed. } \\
\text { (collectivism) }\end{array}$ & & \\
\hline $\begin{array}{l}\text { Mack et } \\
\text { al., } 2010\end{array}$ & English & \begin{tabular}{|l} 
Quantitati \\
ve, \\
interview, \\
medical \\
report \\
analyses
\end{tabular} & ||323 Patients & $\begin{array}{l}\text { Viswanath } \\
\text { et al. } 2007\end{array}$ & $\begin{array}{l}\text { Black vs } \\
\text { White }\end{array}$ & $\begin{array}{l}\text { Oncology } \\
\text {, US }\end{array}$ & $\begin{array}{l}\text { Black pts have less end-of-life discussions and tend } \\
\text { to receive more often life-prolonging measures, } \\
\text { probably because of different communication or } \\
\text { healthcare access }\end{array}$ & Patient & $\mid \begin{array}{l}\text { Medium } \\
(-/+)\end{array}$ \\
\hline $\begin{array}{l}\text { Moreno } \\
\text { et al., } \\
2010\end{array}$ & English & $\begin{array}{l}\text { Quantitati } \\
\text { ve, } \\
\text { interview }\end{array}$ & |1590 Patients & None & $\begin{array}{l}\text { Spanish } \\
\text { speaking } \\
\text { Latino's }\end{array}$ & US & $\begin{array}{l}\text { Needing an interpreter and not having one was } \\
\text { associated with experiences of lower satisfaction } \\
\text { and quality of dr-pt communication (listening, } \\
\text { explaining, respect, time) }\end{array}$ & Patient & Low $(-/-)$ \\
\hline $\begin{array}{l}\text { Sims, } \\
2010\end{array}$ & English & $\begin{array}{l}\text { Mixed, } \\
\text { interview }\end{array}$ & |50 women & None & Black & US & $\begin{array}{l}\text { Disparities in care are influenced by non-clinical } \\
\text { points (i.e. culture). Unfamiliarity with ethnical } \\
\text { different thoughts caused miscommunication and } \\
\text { misinterpretation }\end{array}$ & Patient & Low $(-/-)$ \\
\hline $\begin{array}{l}\text { Manfredi } \\
\text { et al., } \\
2010\end{array}$ & English & \begin{tabular}{|l} 
Quantitati \\
ve, survey \\
(interview
\end{tabular} & ||492 Patients & \begin{tabular}{|l} 
Precede- \\
Proceed \\
Model \\
(Greene\& \\
Kreuter \\
$1999)$ \\
\end{tabular} & $\begin{array}{l}\text { African } \\
\text { American } \\
\text { vs white }\end{array}$ & $\begin{array}{l}\text { Oncology } \\
\text {, US }\end{array}$ & $\begin{array}{l}\text { AA pts reported more interpersonal communication } \\
\text { barriers and have more unmet information needs. } \\
\text { AA pts reported poorer dr-pt communication. AA } \\
\text { pts asked the same amount of questions as White pts } \\
\text { do }\end{array}$ & Patient & $\mid \begin{array}{l}\text { Medium } \\
(+/-)\end{array}$ \\
\hline Peek et & English & Qualitativ & 51 Patients & Shared & African & Diabetes, & Influenced shared DM by pt-related factors (all & Patient & $\operatorname{High}(+/+)$ \\
\hline
\end{tabular}


Paternotte, E., Dulmen, S. van, Lee, N. van der, Scherpbier, A.J.J.A., Scheele, F. Factors influencing intercultural doctor-patient communication: a realist

\begin{tabular}{|c|c|c|c|c|c|c|c|c|c|}
\hline $\begin{array}{c}\text { Author } \\
\text { year }\end{array}$ & $\begin{array}{c}\text { Languag } \\
\mathrm{e}\end{array}$ & $\begin{array}{c}\text { Design \& } \\
\text { Method }\end{array}$ & Participants & Theory & $\begin{array}{c}\text { Ethnicity } \\
\text { patient }\end{array}$ & $\begin{array}{l}\text { Setting, } \\
\text { country }\end{array}$ & Results & $\begin{array}{l}\text { Frame of } \\
\text { reference }\end{array}$ & $\mid \begin{array}{c}\text { Level of } \\
\text { contributi } \\
\text { on }^{1,2,-}\end{array}$ \\
\hline al., 2010 & & $\begin{array}{l}\text { e, } \\
\text { interview } \\
\text { + focus } \\
\text { group }\end{array}$ & & \begin{tabular}{|l} 
decision \\
model \\
(Charles, \\
Gafni\&W \\
helan \\
1997)
\end{tabular} & American & US & $\begin{array}{l}\text { negative): knowledge, attitudes, beliefs, behaviors } \\
\text { Dr-related factors: cultural discordance } \\
\text { (discrimination). Pts believed that their self-efficacy } \\
\text { and communication style accounted for success }\end{array}$ & & \\
\hline $\mid \begin{array}{l}\text { Jean- } \\
\text { Pierre et } \\
\text { al., } 2010\end{array}$ & English & \begin{tabular}{|l} 
Quantitati \\
ve, \\
questionna \\
ire
\end{tabular} & ||973 Patients & None & $\begin{array}{l}\text { White vs } \\
\text { non-White }\end{array}$ & $\begin{array}{l}\text { Oncology } \\
\text {, US }\end{array}$ & $\begin{array}{l}\text { Differences between white vs non-White pts in } \\
\text { concerns of understanding diagnosis and treatment } \\
\text { plan. Non-White pts wanted to have more info }\end{array}$ & Patient & Low $(-/-)$ \\
\hline $\mid \begin{array}{l}\text { Davies et } \\
\text { al., } 2010\end{array}$ & English & \begin{tabular}{|l} 
Qualitativ \\
e, \\
interview \\
(grounded \\
theory)
\end{tabular} & ||36 Parents & none & $\begin{array}{l}\text { Mexican } \\
\text { vs Chinese } \\
\text { vs } \\
\text { American }\end{array}$ & $\begin{array}{l}\text { Pediatrics } \\
\text {, US }\end{array}$ & $\begin{array}{l}\text { Pts who received basic information, explanations } \\
\text { and attention to questions and emotions reported } \\
\text { feeling more informed and less anxious and } \\
\text { distressed. There was a language and a cultural } \\
\text { barrier }\end{array}$ & Parent & $\mid \begin{array}{l}\text { Medium } \\
(-/+)\end{array}$ \\
\hline $\begin{array}{l}\text { Carrion, } \\
200\end{array}$ & English & $\begin{array}{l}\text { Qualitativ } \\
\text { e, } \\
\text { interview }\end{array}$ & 10 Doctors & None & Hispanic & $\begin{array}{l}\text { End-of- } \\
\text { life care, } \\
\text { US }\end{array}$ & $\begin{array}{l}\text { Barriers are: language, uncertainty regarding role of } \\
\text { family and limited knowledge of cultural factors and } \\
\text { beliefs impacted communication related to end-of- } \\
\text { life decisions. There are multiple solutions to } \\
\text { overcome these barriers (for example: training for } \\
\text { dr, more bilingual health staff) }\end{array}$ & Doctor & High $(+/+)$ \\
\hline \begin{tabular}{|l} 
Ruppen \\
et al., \\
2010
\end{tabular} & English & $\begin{array}{l}\text { Quantitati } \\
\text { ve, } \\
\text { document }\end{array}$ & |285 Patients & None & Mixed & $\begin{array}{l}\text { Pain } \\
\text { treatment, } \\
\text { Switzerla }\end{array}$ & $\begin{array}{l}\text { The number of consultations was similar between } \\
\text { the groups. The consultation length was shorter with } \\
\text { immigrant pts }\end{array}$ & Observation & $\operatorname{Bad}(-/-)$ \\
\hline
\end{tabular}


Paternotte, E., Dulmen, S. van, Lee, N. van der, Scherpbier, A.J.J.A., Scheele, F. Factors influencing intercultural doctor-patient communication: a realist

\begin{tabular}{|c|c|c|c|c|c|c|c|c|c|}
\hline $\begin{array}{c}\text { Author } \\
\text { year }\end{array}$ & $\begin{array}{c}\text { Languag } \\
\text { e }\end{array}$ & $\begin{array}{l}\text { Design \& } \\
\text { Method }\end{array}$ & Participants & Theory & $\begin{array}{c}\text { Ethnicity } \\
\text { patient }\end{array}$ & $\begin{array}{l}\text { Setting, } \\
\text { country }\end{array}$ & Results & $\begin{array}{l}\text { Frame of } \\
\text { reference }\end{array}$ & \begin{tabular}{|c} 
Level of \\
contributi \\
on $^{1,2,-*}$
\end{tabular} \\
\hline & & $\begin{array}{l}\text { analyses } \\
\text { (medical } \\
\text { records) }\end{array}$ & & & & nd & & & \\
\hline $\begin{array}{l}\text { Butow et } \\
\text { al., } 2010\end{array}$ & English & \begin{tabular}{|l} 
Qualitativ \\
e, focus \\
group, \\
interview
\end{tabular} & 73 Patients & None & Mixed & $\begin{array}{l}\text { Oncology } \\
\text { Australia }\end{array}$ & $\begin{array}{l}\text { Immigrant pts felt cultural isolated, some felt } \\
\text { judged, but expertise of the dr was respected. Some } \\
\text { pts suspected that they received inferior care. Pts } \\
\text { were concerned that drs gave less information, } \\
\text { because the drs did not take the time to overcome } \\
\text { the communication barrier or used misplaced } \\
\text { paternalism. Some pts found it too hard or } \\
\text { demanding to request clarification and they acted as } \\
\text { if they understood more than they did }\end{array}$ & Patient & High $(+/+)$ \\
\hline $\begin{array}{l}\text { Wallace } \\
\text { et al., } \\
2009\end{array}$ & English & $\begin{array}{l}\text { Quantitati } \\
\text { ve, } \\
\text { interview }\end{array}$ & |5197 Patients & None & Hispanic & \begin{tabular}{|l} 
Health \\
services, \\
US
\end{tabular} & $\begin{array}{l}\text { There are very few differences in perceptions of dr } \\
\text { communication across subgroups. Some reported } \\
\text { that the dr always showed respect for what they had } \\
\text { to say. Others indicated that the dr always spent } \\
\text { enough time }\end{array}$ & Patient & High (+/+) \\
\hline $\begin{array}{l}\text { Jensen et } \\
\text { al., } 2010\end{array}$ & English & $\begin{array}{l}\text { Quantitati } \\
\text { ve, } \\
\text { survey + i } \\
\text { nterview }\end{array}$ & |131 Patients & None & $\begin{array}{l}\text { White vs } \\
\text { Non-White }\end{array}$ & US & $\begin{array}{l}\text { White pts were more likely than non-White pts to } \\
\text { feel that dr did not listen carefully }\end{array}$ & Patient & Low $(-/-)$ \\
\hline $\begin{array}{l}\text { Alegría } \\
\text { et al., } \\
2009\end{array}$ & English & $\begin{array}{l}\text { Quantitati } \\
\text { ve, survey }\end{array}$ & 884 Patients & None & Latino & US & $\begin{array}{l}\text { Us born Latino pts had greater pt activation scores } \\
\text { than foreign born Latino pts. Pt activation was } \\
\text { associated with self-reported quality of care and } \\
\text { better dr-pt communication }\end{array}$ & Patient & $\mid \begin{array}{l}\text { Medium } \\
(+/-)\end{array}$ \\
\hline
\end{tabular}


Paternotte, E., Dulmen, S. van, Lee, N. van der, Scherpbier, A.J.J.A., Scheele, F. Factors influencing intercultural doctor-patient communication: a realist

\begin{tabular}{|c|c|c|c|c|c|c|c|c|c|}
\hline $\begin{array}{c}\text { Author } \\
\text { year }\end{array}$ & $\begin{array}{c}\text { Languag } \\
\text { e }\end{array}$ & $\begin{array}{c}\text { Design \& } \\
\text { Method }\end{array}$ & Participants & Theory & $\begin{array}{c}\text { Ethnicity } \\
\text { patient }\end{array}$ & $\begin{array}{l}\text { Setting, } \\
\text { country }\end{array}$ & Results & $\begin{array}{l}\text { Frame of } \\
\text { reference }\end{array}$ & $\mid \begin{array}{c}\text { Level of } \\
\text { contributi } \\
\text { on }^{1,2, *}\end{array}$ \\
\hline $\begin{array}{c}\text { Garcia et } \\
\text { al., } 2009\end{array}$ & English & $\begin{array}{l}\text { Qualitativ } \\
\text { e, } \\
\text { interview } \\
\end{array}$ & 4 Patients & None & $\begin{array}{l}\text { Latino } \\
\text { immigrants }\end{array}$ & $\begin{array}{l}\text { Adolesce } \\
\text { nts, US }\end{array}$ & $\begin{array}{l}\text { Immigrant pts experienced access disparities } \\
\text { because of language barriers. Language barriers } \\
\text { contributed to feelings of dissatisfaction }\end{array}$ & Patient & $\mid \begin{array}{l}\text { Medium } \\
(-/+)\end{array}$ \\
\hline $\begin{array}{l}\text { Wiking } \\
\text { et al., } \\
2009\end{array}$ & English & \begin{tabular}{|l} 
Qualitativ \\
e, \\
questionna \\
ire
\end{tabular} & $\begin{array}{l}52 \text { Patients, } \\
65 \text { GP }\end{array}$ & None & Mixed & $\begin{array}{l}\text { Health } \\
\text { center, } \\
\text { Sweden }\end{array}$ & $\begin{array}{l}\text { Some pts experienced language difficulties (because } \\
\text { of time, relation problems, explaining of the dr, } \\
\text { expressing of the pt). Most pts experienced respect } \\
\text { for their culture, personality, and their wishes. Most } \\
\text { pts were satisfied with the consultation. Facilitator } \\
\text { dr: understanding viewpoint of pt, willingness to } \\
\text { listen, and experience of personal connection }\end{array}$ & $\begin{array}{l}\text { Patient }+ \text { doct } \\
\text { or }\end{array}$ & $\mid \begin{array}{l}\text { Medium } \\
(-/+)\end{array}$ \\
\hline $\begin{array}{l}\text { O’Brien } \\
\text { et al., } \\
2011\end{array}$ & English & $\begin{array}{l}\text { Quantitati } \\
\text { ve, survey }\end{array}$ & ||1267 Patients & None & Hispanics & US & $\begin{array}{l}\text { Bilingual pts experienced higher satisfaction with } \\
\text { dr-pt communication, than monolingual pt. } \\
\text { Language preference was not significant associated } \\
\text { with pt satisfaction }\end{array}$ & Patient & $\mid \begin{array}{l}\text { Medium } \\
(+/-)\end{array}$ \\
\hline $\begin{array}{l}\text { Cené et } \\
\text { al., } 2009\end{array}$ & English & \begin{tabular}{|l} 
Quantitati \\
ve, \\
interview \\
+ audiotap \\
es
\end{tabular} & $\begin{array}{l}\text { 226 Patients, } \\
39 \text { doctors }\end{array}$ & None & Mixed & $\mid \begin{array}{l}\text { Hypertens } \\
\text { ion, US }\end{array}$ & $\begin{array}{l}\text { Pt race is associated with the quality of pt-dr } \\
\text { communication to a greater extent than blood } \\
\text { pressure control. Black pt with uncontrolled blood } \\
\text { pressure had the shortest visits. Uncontrolled Black } \\
\text { pts had a less emotional positive tone and } \\
\text { experienced worse communication }\end{array}$ & Observer & $\mid \begin{array}{l}\text { Medium } \\
(+/-)\end{array}$ \\
\hline $\begin{array}{l}\text { Shadid et } \\
\text { al., } 2009\end{array}$ & English & $\begin{array}{l}\text { Qualitativ } \\
\text { e, } \\
\text { interview }\end{array}$ & 30 Patients & None & $\begin{array}{l}\text { Aboriginal } \\
\mathrm{s}\end{array}$ & $\mid \begin{array}{l}\text { Oncology } \\
\text { Australia }\end{array}$ & $\begin{array}{l}\text { Barriers for effective communication for pts are: } \\
\text { history and racism, lack of understanding about } \\
\text { culture and life circumstances, an alienating hospital } \\
\text { environment which caused language barriers, } \\
\text { inadequate information and explanation, differences } \\
\text { in comm style, non verbal cues, body language, lack }\end{array}$ & Patient & $\mid \operatorname{High}(+/+)$ \\
\hline
\end{tabular}


Paternotte, E., Dulmen, S. van, Lee, N. van der, Scherpbier, A.J.J.A., Scheele, F. Factors influencing intercultural doctor-patient communication: a realist

\begin{tabular}{|c|c|c|c|c|c|c|c|c|c|}
\hline $\begin{array}{c}\text { Author } \\
\text { year }\end{array}$ & $\begin{array}{c}\text { Languag } \\
\text { e }\end{array}$ & $\begin{array}{c}\text { Design \& } \\
\text { Method }\end{array}$ & Participants & Theory & $\begin{array}{c}\text { Ethnicity } \\
\text { patient }\end{array}$ & $\begin{array}{l}\text { Setting, } \\
\text { country }\end{array}$ & Results & $\begin{array}{l}\text { Frame of } \\
\text { reference }\end{array}$ & $\mid \begin{array}{c}\text { Level of } \\
\text { contributi } \\
\text { on }^{1,2, *}\end{array}$ \\
\hline & & & & & & & $\begin{array}{l}\text { of respect for privacy. Facilitators for pts are: } \\
\text { cultural sensitive dr, empathic personal contact, } \\
\text { acknowledgment and respect for pt culture }\end{array}$ & & \\
\hline $\begin{array}{l}\text { Sudore } \\
\text { et al., } \\
2009\end{array}$ & English & \begin{tabular}{|l} 
Quantitati \\
ve, \\
questionna \\
ire
\end{tabular} & ||771 Patients & None & $\begin{array}{l}\text { Spanish } \\
\text { speaking }\end{array}$ & US & \begin{tabular}{|l} 
Language barriers gave less interactive \\
communication style. Limited health literacy \\
impedes dr-pt communication, but its affect vary \\
with language discordance and comm type \\
(receptine, proactive, interactive)
\end{tabular} & Patient & $\| \begin{array}{l}\text { Medium } \\
(+/-)\end{array}$ \\
\hline $\begin{array}{l}\text { Ge et al., } \\
2009\end{array}$ & English & $\mid \begin{array}{l}\text { Qualitativ } \\
\text { e, } \\
\text { videotapes } \\
\text { + intervie } \\
\text { w }\end{array}$ & | 44 video's & $\begin{array}{l}\text { Hofstede } \\
2001\end{array}$ & Mixed & $\begin{array}{l}\text { Oncology } \\
\text {, US }\end{array}$ & $\begin{array}{l}\text { During consultation there was little attention for } \\
\text { culture. Facilitators for pts are: trust, power distance, } \\
\text { health beliefs, directness, dependency, authoritative } \\
\text { voice knowledge, ability to listen, and expertise of } \\
\text { the dr }\end{array}$ & $\mid \begin{array}{l}\text { Observer }+d \\
\text { octor }+ \text { patien } \\
t\end{array}$ & High $(+/+)$ \\
\hline $\begin{array}{l}\text { Berkman } \\
\text { et al., } \\
2009\end{array}$ & English & $\begin{array}{l}\text { Quantitati } \\
\text { ve, } \\
\text { interview }\end{array}$ & 26 Patients & None & $\begin{array}{l}\text { Korean } \\
\text { American }\end{array}$ & $\begin{array}{l}\text { Oncology } \\
\text {, US }\end{array}$ & $\begin{array}{l}\text { Most pts wanted their dr to tell them the diagnosis. } \\
\text { Some pts preferred disclosure about serious illness. } \\
\text { Pts wanted to understand the dr and wanted the dr to } \\
\text { determine what, how and when for each pt }\end{array}$ & Patient & $\mid \begin{array}{l}\text { Medium } \\
(-/+)\end{array}$ \\
\hline $\begin{array}{l}\text { Wiking } \\
\text { et al., } \\
2009\end{array}$ & English & $\begin{array}{l}\text { Quantitati } \\
\text { ve, } \\
\text { questionna } \\
\text { ire }\end{array}$ & |52 Patients & None & Mixed & GP, & $\begin{array}{l}\text { Most pts experienced respect for their personality, } \\
\text { wishes and culture, and were satisfied. Barriers for } \\
\text { pts were: language and cultural differences, drs that } \\
\text { are unable to listen or to understand }\end{array}$ & Patient & High $(+/+)$ \\
\hline $\begin{array}{l}\text { Eamrano } \\
\text { nd et al., } \\
2009\end{array}$ & English & $\begin{array}{l}\text { Quantitati } \\
\text { ve, } \\
\text { document }\end{array}$ & $\mid \begin{array}{l}306 \text { Patients, } \\
55 \text { doctors }\end{array}$ & None & $\begin{array}{l}\text { Spanish } \\
\text { speaking }\end{array}$ & $\begin{array}{l}\text { Primary } \\
\text { care, US }\end{array}$ & \begin{tabular}{|l} 
Language discordance dr-pt communication \\
documented less about diet and physical activity
\end{tabular} & Observer & Low $(-/-)$ \\
\hline
\end{tabular}


Paternotte, E., Dulmen, S. van, Lee, N. van der, Scherpbier, A.J.J.A., Scheele, F. Factors influencing intercultural doctor-patient communication: a realist

\begin{tabular}{|c|c|c|c|c|c|c|c|c|c|}
\hline $\begin{array}{c}\text { Author } \\
\text { year }\end{array}$ & $\begin{array}{c}\text { Languag } \\
\text { e }\end{array}$ & $\begin{array}{c}\text { Design \& } \\
\text { Method }\end{array}$ & Participants & Theory & $\begin{array}{c}\text { Ethnicity } \\
\text { patient }\end{array}$ & $\begin{array}{l}\text { Setting, } \\
\text { country }\end{array}$ & Results & $\begin{array}{l}\text { Frame of } \\
\text { reference }\end{array}$ & $\mid \begin{array}{c}\text { Level of } \\
\text { contributi } \\
\text { on }^{1,2, *}\end{array}$ \\
\hline & & analyses & & & & & & & \\
\hline $\begin{array}{l}\text { Williams } \\
\text { et al., } \\
2008\end{array}$ & English & $\mid \begin{array}{l}\text { Qualitativ } \\
\text { e, focus } \\
\text { groups }\end{array}$ & 42 Patients & None & $\begin{array}{l}\text { African } \\
\text { American }\end{array}$ & $\begin{array}{l}\text { Oncology } \\
\text {, US }\end{array}$ & $\begin{array}{l}\text { Effective communication and decision making are } \\
\text { fundamental to overall quality of life. Drs were } \\
\text { viewed as having the responsibility to establish and } \\
\text { monitor effective communication. Drs needed to } \\
\text { know the pts and family and tailor communication } \\
\text { on this knowledge (appropriate language and } \\
\text { amount and timing of information) }\end{array}$ & Patient & $\mid \operatorname{High}(+/+)$ \\
\hline $\begin{array}{l}\text { Julliard } \\
\text { et al., } \\
2008\end{array}$ & English & $\begin{array}{l}\text { Qualitativ } \\
\text { e, } \\
\text { interview } \\
\text { (grounded } \\
\text { theory) }\end{array}$ & |28 women & None & Latina & US & $\begin{array}{l}\text { Dr-pt relationship is very important. Pts will not } \\
\text { share information if the dr is has no compassion, } \\
\text { trust, caring, human interest and respect. Pts } \\
\text { experienced difficulty disclosing information } \\
\text { because of language barrier. Barriers were time } \\
\text { constraints and cultural differences. Pts expressed } \\
\text { that being listened and heard by drs were important } \\
\end{array}$ & Patient & High $(+/+)$ \\
\hline $\begin{array}{l}\text { Korthuis } \\
\text { et al., } \\
2008\end{array}$ & English & $\begin{array}{l}\text { Quantitati } \\
\text { ve, } \\
\text { interviews }\end{array}$ & 717 Patients & None & Mixed & US & $\begin{array}{l}\text { The relationship between pt-centered } \\
\text { communication and race is complex. Most pt rated } \\
\text { dr communication favorably. Black pt reported more } \\
\text { positive experiences than White pt. Pts reported that } \\
\text { drs explain things, listen and respects }\end{array}$ & Patient & $\mid \begin{array}{l}\text { Medium } \\
(-/+)\end{array}$ \\
\hline $\begin{array}{l}\text { Wallace } \\
\text { et al., } \\
2009\end{array}$ & English & \begin{tabular}{|l} 
Quantitati \\
ve, \\
telephone \\
interview
\end{tabular} & ||5197 Patients & None & $\begin{array}{l}\text { English } \\
\text { speaking } \\
\text { or Spanish } \\
\text { speaking }\end{array}$ & US & $\begin{array}{l}\text { English pts reported positively about } \\
\text { communication with the dr. Most English } \\
\text { responders reported that the dr listened, explained, } \\
\text { showed respect, spent enough time and ask to help } \\
\text { the pt in making the decision }\end{array}$ & Patient & High $(+/+)$ \\
\hline
\end{tabular}


Paternotte, E., Dulmen, S. van, Lee, N. van der, Scherpbier, A.J.J.A., Scheele, F. Factors influencing intercultural doctor-patient communication: a realist

\begin{tabular}{|c|c|c|c|c|c|c|c|c|c|}
\hline $\begin{array}{c}\text { Author } \\
\text { year }\end{array}$ & $\begin{array}{c}\text { Languag } \\
\mathbf{e}\end{array}$ & $\mid \begin{array}{c}\text { Design \& } \\
\text { Method }\end{array}$ & Participants & Theory & $\begin{array}{c}\text { Ethnicity } \\
\text { patient }\end{array}$ & $\begin{array}{l}\text { Setting, } \\
\text { country }\end{array}$ & Results & $\begin{array}{l}\text { Frame of } \\
\text { reference }\end{array}$ & $\mid \begin{array}{c}\text { Level of } \\
\text { contributi } \\
\text { on }^{1,2,-*}\end{array}$ \\
\hline $\begin{array}{l}\text { Hawley } \\
\text { et al., } \\
2008\end{array}$ & English & \begin{tabular}{|l} 
Quantitati \\
ve, \\
questionna \\
ire
\end{tabular} & |877 women & None & Mixed & $\begin{array}{l}\text { Oncology } \\
\text {, US }\end{array}$ & \begin{tabular}{|l} 
Despite similar outcomes, pts reported very different \\
experiences with treatment decision making. Latina \\
pts have the highest decision dissatisfaction. Ethnic \\
minority pts more often preferred interpersonal \\
sources of information
\end{tabular} & Patient & Low $(-/-)$ \\
\hline $\begin{array}{l}\text { Harmsen } \\
\text { et al., } \\
2008\end{array}$ & English & $\begin{array}{l}\text { Quantitati } \\
\text { ve, } \\
\text { interview }\end{array}$ & \begin{tabular}{||}
663 Patients, \\
38 doctors
\end{tabular} & None & $\begin{array}{l}\text { Western vs } \\
\text { non } \\
\text { Western }\end{array}$ & $\begin{array}{l}\text { GP's, The } \\
\text { Netherlan } \\
\text { ds }\end{array}$ & $\begin{array}{l}\text { Cultural views and language proficiency are more } \\
\text { important for the evaluation of care than ethnic } \\
\text { origin. Non-Western pts perceived less quality of } \\
\text { care and were less satisfied than Dutch-born pts. } \\
\text { With bad Dutch language proficiency, pts were } \\
\text { more negative about the communication process }\end{array}$ & Patient & High $(+/+)$ \\
\hline $\mid \begin{array}{l}\text { Street et } \\
\text { al., } 2008\end{array}$ & English & $\begin{array}{l}\text { Quantitati } \\
\text { ve, cross } \\
\text { sectional }\end{array}$ & \begin{tabular}{||}
214 Patients, \\
29 doctors
\end{tabular} & None & Mixed & $\begin{array}{l}\text { Outpatien } \\
\text { t clinic, } \\
\text { US }\end{array}$ & \begin{tabular}{|l|} 
Race concordance is primarily predictor of \\
perceived ethnic similarity, but several factors affect \\
perceived personal similarity, including drs' use of \\
pt-centered communication
\end{tabular} & Patient & Low $(-/-)$ \\
\hline $\begin{array}{l}\text { Babitsch } \\
\text { et al., } \\
2008\end{array}$ & English & \begin{tabular}{|l|} 
Quantitati \\
ve, \\
questionna \\
ire, \\
documents \\
\end{tabular} & ||2429 Doctors & None & $\begin{array}{l}\text { Turkish vs } \\
\text { German }\end{array}$ & $\begin{array}{l}\text { Emergenc } \\
\text { y } \\
\text { departme } \\
\text { nt, } \\
\text { Germany }\end{array}$ & $\begin{array}{l}\text { Good communication is crucial for satisfaction dr - } \\
\text { pt, dr satisfaction is significant lower with ethnic } \\
\text { different pts. Language barriers have negative } \\
\text { impact on dr-pt relationship and satisfactory of the } \\
\text { dr }\end{array}$ & Doctor & $\begin{array}{l}\text { medium } \\
(-/+)\end{array}$ \\
\hline $\begin{array}{l}\text { Levinson } \\
\text { et al., } \\
2008\end{array}$ & English & \begin{tabular}{|l|} 
Quantitati \\
ve, \\
audiotapes \\
+ questio \\
nnaire \\
\end{tabular} & $\mid \begin{array}{l}886 \text { Patients, } \\
89 \text { doctors }\end{array}$ & None & $\begin{array}{l}\text { African } \\
\text { American } \\
\text { vs White }\end{array}$ & $\begin{array}{l}\text { Surgery, } \\
\text { US }\end{array}$ & $\begin{array}{l}\text { White pts rated the communication and satisfaction } \\
\text { higher than Black pts. The content of informed DM } \\
\text { conversations does not differ by race }\end{array}$ & $\begin{array}{l}\text { Patient + obs } \\
\text { erver }\end{array}$ & $\mid \begin{array}{l}\text { medium } \\
(+/-)\end{array}$ \\
\hline
\end{tabular}


Paternotte, E., Dulmen, S. van, Lee, N. van der, Scherpbier, A.J.J.A., Scheele, F. Factors influencing intercultural doctor-patient communication: a realist

\begin{tabular}{|c|c|c|c|c|c|c|c|c|c|}
\hline $\begin{array}{c}\text { Author } \\
\text { year }\end{array}$ & $\begin{array}{c}\text { Languag } \\
\text { e }\end{array}$ & $\mid \begin{array}{c}\text { Design \& } \\
\text { Method }\end{array}$ & Participants & Theory & $\begin{array}{c}\text { Ethnicity } \\
\text { patient }\end{array}$ & $\begin{array}{l}\text { Setting, } \\
\text { country }\end{array}$ & Results & $\begin{array}{l}\text { Frame of } \\
\text { reference }\end{array}$ & $\mid \begin{array}{c}\text { Level of } \\
\text { contributi } \\
\text { on }^{1,2,-*}\end{array}$ \\
\hline $\begin{array}{l}\text { Schouten } \\
\text { et al., } \\
2009\end{array}$ & English & \begin{tabular}{|} 
Qualitativ \\
e, \\
videotapes \\
+ survey
\end{tabular} & \begin{tabular}{||}
103 Patients, \\
29 doctors
\end{tabular} & $\begin{array}{l}\text { Roberts et } \\
\text { al. } 2002\end{array}$ & Mixed & $\begin{array}{l}\text { GP's, The } \\
\text { Netherlan } \\
\text { ds }\end{array}$ & $\begin{array}{l}\text { GP's interacted less stimulatingly with minority pts. } \\
\text { Consults with ethnic minority pts were with less } \\
\text { stimulating utterances, less 'joint problem solving' } \\
\text { and less schema-driven. Drs involved ethnic minor } \\
\text { pts less in the DM process and checked less often } \\
\text { whether they understand }\end{array}$ & Observer & High $(+/+)$ \\
\hline $\begin{array}{l}\text { Kushnir } \\
\text { et al., } \\
2008\end{array}$ & English & $\begin{array}{l}\text { Quantitati } \\
\text { ve, } \\
\text { questionna } \\
\text { ire }\end{array}$ & |193 Patients & None & \begin{tabular}{||} 
Jewish, \\
Bedouin
\end{tabular} & \begin{tabular}{|l} 
Pediatric, \\
Israel
\end{tabular} & \begin{tabular}{|l} 
Interpersonal competence and skills of drs were \\
important. Global trust in the dr was predicted by \\
interest and collaboration communication styles, but \\
ethnicity was not a significant predictor. The only \\
cultural difference was that Jewish pts reported \\
significantly higher scores than Bedouin pts on \\
collaboration (having common language and similar \\
values)
\end{tabular} & Parents & High $(+/+)$ \\
\hline $\begin{array}{l}\text { Ghods et } \\
\text { al., } 2008\end{array}$ & English & \begin{tabular}{|} 
Quantitati \\
ve, \\
audiotapes \\
+ questio \\
nnaire
\end{tabular} & $\begin{array}{l}108 \text { Patients, } \\
54 \text { doctor }\end{array}$ & None & \begin{tabular}{|l} 
African \\
American \\
vs White
\end{tabular} & $\begin{array}{l}\text { Depressio } \\
\text { n care, } \\
\text { US }\end{array}$ & \begin{tabular}{|l} 
There were no differences is biomedical or \\
psychosocial statements. AA pts reported less \\
rapport building exchange. No different in duration \\
of the visit. Dr and pt positive affect were lower in \\
visits of minority pts. AA pts provided cues about \\
their emotional status
\end{tabular} & $\begin{array}{l}\text { Observer + d } \\
\text { octor }\end{array}$ & High $(+/+)$ \\
\hline $\begin{array}{l}\text { Ngo- } \\
\text { Metzger } \\
\text { et al., } \\
2007 \\
\end{array}$ & English & $\mid \begin{array}{l}\text { Quantitati } \\
\text { ve, survey }\end{array}$ & ||2746 Patients & None & \begin{tabular}{|l} 
Asian \\
American
\end{tabular} & \begin{tabular}{|l} 
Communi \\
ty health \\
center, \\
US \\
\end{tabular} & $\begin{array}{l}\text { Language barriers were associated with less health } \\
\text { education, worse interpersonal care and lower pt } \\
\text { satisfaction }\end{array}$ & Patient & High $(+/+)$ \\
\hline Nguyen & English & Qualitativ & 20 Patients & None & Vietnames & Oncology & Pts were unsatisfied with the dr-pt communication, & Patient & High $(+/+)$ \\
\hline
\end{tabular}

This is a NIVEL certified Post Print, more info at http://www.nivel.eu 
Paternotte, E., Dulmen, S. van, Lee, N. van der, Scherpbier, A.J.J.A., Scheele, F. Factors influencing intercultural doctor-patient communication: a realist

\begin{tabular}{|c|c|c|c|c|c|c|c|c|c|}
\hline $\begin{array}{c}\text { Author } \\
\text { year }\end{array}$ & $\begin{array}{c}\text { Languag } \\
\text { e }\end{array}$ & $\begin{array}{l}\text { Design \& } \\
\text { Method }\end{array}$ & Participants & Theory & $\begin{array}{c}\text { Ethnicity } \\
\text { patient }\end{array}$ & $\begin{array}{l}\text { Setting, } \\
\text { country }\end{array}$ & Results & $\begin{array}{l}\text { Frame of } \\
\text { reference }\end{array}$ & $\mid \begin{array}{c}\text { Level of } \\
\text { contributi } \\
\text { on }^{1,2, *}\end{array}$ \\
\hline 2008 & & \begin{tabular}{|l} 
e, \\
interview \\
(grounded \\
theory)
\end{tabular} & & & $\mathrm{e}$ & , US & $\begin{array}{l}\text { because discussions were not always taking place; } \\
\text { drs didn't talk about cancer and language } \\
\text { difficulties. Pts accepted a paternalistic dr-pt } \\
\text { relationship }\end{array}$ & & \\
\hline $\begin{array}{l}\text { Wearn et } \\
\text { al., } 2007\end{array}$ & English & $\begin{array}{l}\text { Qualitativ } \\
\text { e, mixed, } \\
\text { interview }\end{array}$ & 80 Doctors & None & Mixed & $\begin{array}{l}\text { GP's, } \\
\text { New } \\
\text { Zealand }\end{array}$ & $\begin{array}{l}\text { Non-English consultations were associated with } \\
\text { higher misunderstanding and interpretation } \\
\text { difficulties, because of language difficulties. } \\
\text { Information sharing was impeded with language } \\
\text { difficulties, which gave worries about compliance, } \\
\text { diagnosis and understanding of the pt. The effect of } \\
\text { different cultural norms was seen as additional to } \\
\text { issues produced by language alone }\end{array}$ & Doctor & High $(+/+)$ \\
\hline \begin{tabular}{|l} 
Wallace \\
et al., \\
2007
\end{tabular} & English & \begin{tabular}{|l} 
Quantitati \\
ve, \\
telephone \\
interview
\end{tabular} & \begin{tabular}{||l}
19.6 million \\
households
\end{tabular} & None & $\begin{array}{l}\text { Hispanic } \\
\text { White vs } \\
\text { non- } \\
\text { Hispanic } \\
\text { White } \\
\end{array}$ & $\begin{array}{l}\text { Civilian } \\
\text { research, } \\
\text { US }\end{array}$ & $\begin{array}{l}\text { Hispanic pts reported that their dr listened, } \\
\text { explained, showed respect, spent enough time, but } \\
\text { reported that the dr gave them control overtreatment } \\
\text { options }\end{array}$ & Patient & High $(+/+)$ \\
\hline $\mid \begin{array}{l}\text { Smith et } \\
\text { al., } 2007\end{array}$ & English & \begin{tabular}{|l} 
Quantitati \\
ve, survey
\end{tabular} & 803 Patients & None & \begin{tabular}{|l} 
African- \\
American \\
vs White \\
\end{tabular} & $\begin{array}{l}\text { End-of- } \\
\text { life care, } \\
\text { US }\end{array}$ & $\begin{array}{l}\text { Quality of dr-pt relation (respect, listening, DM) } \\
\text { was worse for AA pts, except trust }\end{array}$ & Patient & $\mid \begin{array}{l}\text { Medium } \\
(+/-)\end{array}$ \\
\hline $\mid \begin{array}{l}\text { Probst et } \\
\text { al., } 2007\end{array}$ & English & \begin{tabular}{|l} 
Quantitati \\
ve, survey
\end{tabular} & ||1766 Patients & None & Mixed & $\begin{array}{l}\text { Depressio } \\
\text { n, US }\end{array}$ & $\begin{array}{l}\text { White pts and Hispanic pts were more likely to } \\
\text { communicate about symptoms of depression with } \\
\text { the dr than AA }\end{array}$ & Patient & Low $(-/-)$ \\
\hline Schouten & English & Quantitati & 103 Patients, & Street et & Mixed & GP, the & Non Western ethnic minority pts displayed less & Observer $+\mathrm{p}$ & $\operatorname{High}(+/+)$ \\
\hline
\end{tabular}


Paternotte, E., Dulmen, S. van, Lee, N. van der, Scherpbier, A.J.J.A., Scheele, F. Factors influencing intercultural doctor-patient communication: a realist

\begin{tabular}{|c|c|c|c|c|c|c|c|c|c|}
\hline $\begin{array}{c}\text { Author } \\
\text { year }\end{array}$ & $\begin{array}{c}\text { Languag } \\
\text { e }\end{array}$ & $\mid \begin{array}{c}\text { Design \& } \\
\text { Method }\end{array}$ & Participants & Theory & $\begin{array}{c}\text { Ethnicity } \\
\text { patient }\end{array}$ & $\begin{array}{l}\text { Setting, } \\
\text { country }\end{array}$ & Results & $\begin{array}{l}\text { Frame of } \\
\text { reference }\end{array}$ & $\mid \begin{array}{c}\text { Level of } \\
\text { contributi } \\
\text { on }^{1,2,-}\end{array}$ \\
\hline $\begin{array}{l}\text { et al., } \\
2007\end{array}$ & & \begin{tabular}{|l|} 
ve, \\
videotapes \\
+ questio \\
nnaire + in \\
terview
\end{tabular} & 29 doctors & al. 2002 & & $\begin{array}{l}\text { Netherlan } \\
\text { ds }\end{array}$ & \begin{tabular}{|l} 
participatory behavior during consultations and less \\
self-diagnose than Dutch pt. Dutch pts asked more \\
(in) direct questions. Drs instrumental and affective \\
behavior was lower in ethnic minority pts
\end{tabular} & $\begin{array}{l}\text { atient + docto } \\
\mathrm{r}\end{array}$ & \\
\hline $\mid \begin{array}{l}\text { Meeuwe } \\
\text { sen et al., } \\
2007\end{array}$ & English & $\begin{array}{l}\text { Quantitati } \\
\text { ve, } \\
\text { videotapes }\end{array}$ & ||103 Patients & None & Mixed & $\begin{array}{l}\text { GP, the } \\
\text { Netherlan } \\
\text { ds }\end{array}$ & $\begin{array}{l}\text { Drs set the agenda. Majority of the consults was } \\
\text { traditional or cooperative, especially with minority } \\
\text { pts. A conflicting pattern will lead to poor mutual } \\
\text { understanding }\end{array}$ & Observer & High $(+/+)$ \\
\hline $\mid \begin{array}{l}\text { Kokanov } \\
\text { ic et al., } \\
2007\end{array}$ & English & $\begin{array}{l}\text { Qualitativ } \\
\text { e, } \\
\text { interview }\end{array}$ & |30 Patients & None & Mixed & $\mid$\begin{tabular}{|l} 
Diabetes, \\
Australia
\end{tabular} & $\begin{array}{l}\text { Dr used normalizing or catastrophizing strategies. } \\
\text { Some pts reported that they received only general } \\
\text { information (normalizing), while others reported } \\
\text { that the information was difficult to comprehend } \\
\text { (catastrophizing). The relationship was hierarchical } \\
\end{array}$ & Patient & High $(+/+)$ \\
\hline $\mid \begin{array}{l}\text { Rosenber } \\
\text { g et al., } \\
2007\end{array}$ & English & $\begin{array}{l}\text { Qualitativ } \\
\text { e, } \\
\text { interview }\end{array}$ & 23 Doctors & None & mixed & $\begin{array}{l}\text { GP, } \\
\text { Canada }\end{array}$ & $\begin{array}{l}\text { Most drs focused on the individual pt. Pt-centered } \\
\text { model of care worked effectively in different } \\
\text { cultures, but drs had no framework to elicit } \\
\text { information about pt' culture. Main strategies of dr } \\
\text { were: pt adaption, dr adaption and negotiation }\end{array}$ & Doctor & $\mid \begin{array}{l}\text { medium } \\
(-/+)\end{array}$ \\
\hline$\left|\begin{array}{l}\text { Schlemm } \\
\text { er et al. J } \\
2006\end{array}\right|$ & English & $\begin{array}{l}\text { Qualitativ } \\
\text { e, focus } \\
\text { groups } \\
\text { and } \\
\text { interview }\end{array}$ & $\mid \begin{array}{l}5 \text { Patients, } 6 \\
\text { doctors }\end{array}$ & None & $\mid \begin{array}{l}\text { Xhosa } \\
\text { speaking }\end{array}$ & $\begin{array}{l}\text { South } \\
\text { Africa }\end{array}$ & \begin{tabular}{|l|} 
Drs had negative attitudes towards Xhosa speaking \\
pts, because of their previous experiences. Dr \\
experienced that pts didn’t understand the diagnosis \\
and medication use. Pts reported that respect implies \\
not querying anything the dr says. Language barriers \\
negatively influenced the attitudes of drs and pts \\
\end{tabular} & $\begin{array}{l}\text { Doctor + pati } \\
\text { ent }\end{array}$ & High $(+/+)$ \\
\hline
\end{tabular}


Paternotte, E., Dulmen, S. van, Lee, N. van der, Scherpbier, A.J.J.A., Scheele, F. Factors influencing intercultural doctor-patient communication: a realist

\begin{tabular}{|c|c|c|c|c|c|c|c|c|c|}
\hline $\begin{array}{c}\text { Author } \\
\text { year }\end{array}$ & $\begin{array}{c}\text { Languag } \\
\text { e }\end{array}$ & $\begin{array}{l}\text { Design \& } \\
\text { Method }\end{array}$ & Participants & Theory & $\begin{array}{c}\text { Ethnicity } \\
\text { patient }\end{array}$ & $\begin{array}{l}\text { Setting, } \\
\text { country }\end{array}$ & Results & $\begin{array}{l}\text { Frame of } \\
\text { reference }\end{array}$ & $\mid \begin{array}{c}\text { Level of } \\
\text { contributi } \\
\text { on }^{1,2, *}\end{array}$ \\
\hline $\begin{array}{l}\text { Levin et } \\
\text { al., } 2006\end{array}$ & English & \begin{tabular}{|l} 
Qualitativ \\
e, \\
questionna \\
ire
\end{tabular} & 53 Patients & None & $\begin{array}{l}\text { Xhosa } \\
\text { speaking }\end{array}$ & $\begin{array}{l}\text { Pediatrics } \\
\text {, South } \\
\text { Africa }\end{array}$ & \begin{tabular}{|l} 
Language and cultural barriers were cited as \\
barriers. Pts experienced difficulties in \\
understanding the dr (terminology), making \\
themselves understood and asking questions. Pts \\
blame on their own linguistic limitation
\end{tabular} & Parents & High $(+/+)$ \\
\hline $\begin{array}{l}\text { Mutchler } \\
\text { et al., } \\
2007\end{array}$ & English & $\begin{array}{l}\text { Qualitativ } \\
\text { e, focus } \\
\text { groups }\end{array}$ & |36 Patients & None & Latino & US & $\begin{array}{l}\text { Language was a barrier in dealing with medications. } \\
\text { Language issues were being linked to perceptions of } \\
\text { discrimination. Pts were actively involved in their } \\
\text { health care communication obstacles prevent } \\
\text { understanding and participation in DM. Trust is } \\
\text { related to language and a key component for pt DM }\end{array}$ & Patient & High $(+/+)$ \\
\hline $\mid \begin{array}{l}\text { Ali et al., } \\
2006\end{array}$ & English & $\begin{array}{l}\text { Qualitativ } \\
\text { e, } \\
\text { interview }\end{array}$ & 25 Patients & None & $\begin{array}{l}\text { South } \\
\text { Asian vs } \\
\text { White }\end{array}$ & $\begin{array}{l}\text { GP, Great } \\
\text { Britain }\end{array}$ & \begin{tabular}{|l} 
Pts wanted a dr-centered approach. South-Asian pts \\
had less social conversation. Drs were good \\
listeners. Time management was important for drs to \\
have. 'Foreign ambience syndrome', where pts were \\
seen to complain about trivial matters in which \\
communication between drs and pts is adversely \\
effected by the linguistic incompetence of pt \\
\end{tabular} & Patient & High $(+/+)$ \\
\hline $\begin{array}{l}\text { Meeuwe } \\
\text { sen et al., } \\
2006\end{array}$ & English & \begin{tabular}{|l} 
Quantitati \\
ve, video \\
observatio \\
n
\end{tabular} & $\mid \begin{array}{l}144 \\
\text { video's/patient } \\
\text { s, } 31 \text { doctors }\end{array}$ & None & Mixed & $\begin{array}{l}\text { GP, The } \\
\text { Netherlan } \\
\text { ds }\end{array}$ & \begin{tabular}{|l|} 
Consultation with minority pts were shorter, greater \\
power distance, drs ask for clarification, gave advice \\
and paraphrased more. Pts of ethnic majority talked \\
more and were more often disagreed with the dr. Dr \\
instrumental communication was similar, but less \\
affective communication in minority group \\
\end{tabular} & Observer & High $(+/+)$ \\
\hline $\begin{array}{l}\text { Gordon } \\
\text { et al., }\end{array}$ & English & \begin{tabular}{|l} 
Mixed, \\
audiotapes
\end{tabular} & ||137 Patients & None & Mixed & $\begin{array}{l}\text { Oncology } \\
\text {, US }\end{array}$ & $\begin{array}{l}\text { Minority pts received less information from dr and } \\
\text { were less active in the consultation }\end{array}$ & Observer & High $(+/+)$ \\
\hline
\end{tabular}

This is a NIVEL certified Post Print, more info at http://www.nivel.eu 
Paternotte, E., Dulmen, S. van, Lee, N. van der, Scherpbier, A.J.J.A., Scheele, F. Factors influencing intercultural doctor-patient communication: a realist

\begin{tabular}{|c|c|c|c|c|c|c|c|c|c|}
\hline $\begin{array}{c}\text { Author } \\
\text { year }\end{array}$ & $\begin{array}{c}\text { Languag } \\
\mathbf{e}\end{array}$ & $\begin{array}{c}\text { Design \& } \\
\text { Method }\end{array}$ & Participants & Theory & $\begin{array}{c}\text { Ethnicity } \\
\text { patient }\end{array}$ & $\begin{array}{l}\text { Setting, } \\
\text { country }\end{array}$ & Results & $\begin{array}{l}\text { Frame of } \\
\text { reference }\end{array}$ & $\mid \begin{array}{c}\text { Level of } \\
\text { contributi } \\
\text { on }^{1,2, *}\end{array}$ \\
\hline 2006 & & analyses & & & & & & & \\
\hline $\begin{array}{l}\text { Towle et } \\
\text { al., } 2006\end{array}$ & English & \begin{tabular}{|l} 
Qualitativ \\
e, \\
interview \\
+ focus \\
group
\end{tabular} & $\begin{array}{l}\text { 22 Patients, } 2 \\
\text { doctors }\end{array}$ & $\begin{array}{l}\text { Kelly\&Br } \\
\text { own } 2002\end{array}$ & $\begin{array}{l}\text { Aboriginal } \\
\text { s }\end{array}$ & Canada & $\begin{array}{l}\text { Barriers in communication were time and history. A } \\
\text { facilitator was trust. Pts wanted to be treated as } \\
\text { individuals and want time to be heard. Drs needed to } \\
\text { understand the history of the pt to build a personal } \\
\text { relationship. With negative experiences, pts saw } \\
\text { healthcare negative }\end{array}$ & $\begin{array}{l}\text { Patient }+ \text { doct } \\
\text { or }\end{array}$ & High $(+/+)$ \\
\hline $\begin{array}{l}\text { Siminoff } \\
\text { et al., } \\
2006\end{array}$ & English & $\begin{array}{l}\text { Quantitati } \\
\text { ve, } \\
\text { audiotapes }\end{array}$ & $\mid \begin{array}{l}405 \text { Patients, } \\
58 \text { doctors }\end{array}$ & None & $\begin{array}{l}\text { White vs } \\
\text { non-white }\end{array}$ & $\begin{array}{l}\text { Oncology } \\
\text {, US }\end{array}$ & $\begin{array}{l}\text { Both pts and drs spent time to establish an } \\
\text { interpersonal relationship. White pts had more } \\
\text { utterances, asked more questions, more involvement } \\
\text { in the DM process and gave more biomedical } \\
\text { information }\end{array}$ & Observer & High $(+/+)$ \\
\hline $\begin{array}{l}\text { Abbe et } \\
\text { al., } 2006\end{array}$ & English & \begin{tabular}{|l|} 
Mixed, \\
questionna \\
ire
\end{tabular} & 17 Patients & None & $\begin{array}{l}\text { Spanish } \\
\text { speaking }\end{array}$ & $\begin{array}{l}\text { Oncology } \\
\text {, US }\end{array}$ & $\begin{array}{l}\text { Pts felt scared and worried that they wouldn’t } \\
\text { understand what the dr had to say. Pt preferred } \\
\text { simple language }\end{array}$ & Patient & Low $(-/-)$ \\
\hline $\begin{array}{l}\text { Gonzale } \\
\text { x-Espada } \\
\text { et al., } \\
2006\end{array}$ & English & $\begin{array}{l}\text { Qualitativ } \\
\text { e, } \\
\text { interview }\end{array}$ & \begin{tabular}{|l}
13 Patients, \\
17 doctors
\end{tabular} & None & Hispanic & $\begin{array}{l}\text { Pediatrics } \\
\text {, US }\end{array}$ & $\begin{array}{l}\text { Pts felt frustration, uncomfortable and helplessness } \\
\text { with a language barrier to understand the dr. Drs } \\
\text { reported importance of awareness of cultures and } \\
\text { limited ability to understand and speak the same } \\
\text { language, which brought concerns about the } \\
\text { diagnosis }\end{array}$ & $\begin{array}{l}\text { Patient }+ \text { doct } \\
\text { or }\end{array}$ & High $(+/+)$ \\
\hline $\begin{array}{l}\text { Gordon } \\
\text { et al., } \\
2006\end{array}$ & English & \begin{tabular}{|l|} 
Quantitati \\
ve, \\
questionna \\
ire
\end{tabular} & 103 Patients & None & $\begin{array}{l}\text { Black vs } \\
\text { White }\end{array}$ & $\begin{array}{l}\text { Oncology } \\
\text {, US }\end{array}$ & $\begin{array}{l}\text { Pts reported that drs communicated less supportive, } \\
\text { less partnering, less informative with Black pts, } \\
\text { which gave lower trust. }\end{array}$ & Patient & $\begin{array}{l}\text { Moderate } \\
(-/+)\end{array}$ \\
\hline
\end{tabular}


Paternotte, E., Dulmen, S. van, Lee, N. van der, Scherpbier, A.J.J.A., Scheele, F. Factors influencing intercultural doctor-patient communication: a realist

\begin{tabular}{|c|c|c|c|c|c|c|c|c|c|}
\hline $\begin{array}{c}\text { Author } \\
\text { year }\end{array}$ & $\begin{array}{c}\text { Languag } \\
\text { e }\end{array}$ & $\begin{array}{l}\text { Design \& } \\
\text { Method }\end{array}$ & Participants & Theory & $\begin{array}{c}\text { Ethnicity } \\
\text { patient }\end{array}$ & $\begin{array}{l}\text { Setting, } \\
\text { country }\end{array}$ & Results & $\begin{array}{l}\text { Frame of } \\
\text { reference }\end{array}$ & $\mid \begin{array}{c}\text { Level of } \\
\text { contributi } \\
\text { on }^{1,2, *}\end{array}$ \\
\hline $\begin{array}{l}\text { Goldstei } \\
\text { n et al., } \\
2005\end{array}$ & English & \begin{tabular}{|l} 
Quantitati \\
ve, \\
interview \\
+ question \\
naire
\end{tabular} & $\begin{array}{l}\text { 214 Patients, } \\
92 \text { doctors }\end{array}$ & None & Mixed & \begin{tabular}{|l} 
End-of- \\
life care, \\
US
\end{tabular} & $\begin{array}{l}\text { Discussions about prognosis occurred more often in } \\
\text { non-white pts }\end{array}$ & $\begin{array}{l}\text { Patient }+ \text { doct } \\
\text { or }\end{array}$ & Low $(-/-)$ \\
\hline $\begin{array}{l}\text { Shrank } \\
\text { et al., } \\
2005\end{array}$ & English & $\begin{array}{l}\text { Qualitativ } \\
\text { e, focus } \\
\text { groups }\end{array}$ & 70 Patients & None & $\begin{array}{l}\text { African } \\
\text { American } \\
\text { vs White }\end{array}$ & $\begin{array}{l}\text { End-of- } \\
\text { life care, } \\
\text { US }\end{array}$ & \begin{tabular}{|l} 
White pts desired more information about medical \\
options; AA pts requested spiritually focused \\
information. White pts expressed more concern with \\
quality of life while AA pts tended to protection of \\
life at all costs (quantity more important than \\
quality). Pts wanted an autonomous decision with \\
the family
\end{tabular} & Patient & High $(+/+)$ \\
\hline $\begin{array}{l}\text { Rosenber } \\
\text { g et al., } \\
2006\end{array}$ & English & $\begin{array}{l}\text { Qualitativ } \\
\text { e, video } \\
\text { vignette }\end{array}$ & $\mid \begin{array}{l}24 \\
\text { video's/patient } \\
\text { s, } 12 \text { doctors }\end{array}$ & $\begin{array}{l}\text { Identity } \\
\text { and Co- } \\
\text { cultural } \\
\text { Theory }\end{array}$ & Mixed & $\begin{array}{l}\text { Family } \\
\text { medicine, } \\
\text { Canada }\end{array}$ & $\begin{array}{l}\text { Pts often made errors in word use and were } \\
\text { conscious of differencing accents that may make it } \\
\text { more difficult to be understood. Pts failed to } \\
\text { understand the dr, but didn’t ask for clarification. } \\
\text { Drs reported that pts have limited ability to describe } \\
\text { symptoms; pts used expressions that were difficult } \\
\text { for the dr to decode. Language was a barrier. The } \\
\text { interaction was seen as interpersonal rather than } \\
\text { intercultural. Dr didn't know the effect of culture on } \\
\text { communication }\end{array}$ & $\begin{array}{l}\text { Patient + Doc } \\
\text { tor }\end{array}$ & High $(+/+)$ \\
\hline $\begin{array}{l}\text { Moss et } \\
\text { al., } 2005\end{array}$ & English & $\begin{array}{l}\text { Qualitativ } \\
\text { e, video } \\
\text { observatio }\end{array}$ & $\mid \begin{array}{l}232 \\
\text { video's/patient } \\
\text { s, } 19 \text { doctors }\end{array}$ & None & Mixed & GP, UK & \begin{tabular}{|l} 
Misunderstanding arises owing to a range of \\
linguistic and cultural factors. Including stress and \\
intonation patterns, vocabulary, narrative of pts and \\
the different agendas of drs and pts. The indirectness
\end{tabular} & Observer & High $(+/+)$ \\
\hline
\end{tabular}


Paternotte, E., Dulmen, S. van, Lee, N. van der, Scherpbier, A.J.J.A., Scheele, F. Factors influencing intercultural doctor-patient communication: a realist

\begin{tabular}{|c|c|c|c|c|c|c|c|c|c|}
\hline $\begin{array}{c}\text { Author } \\
\text { year }\end{array}$ & $\begin{array}{c}\text { Languag } \\
\text { e }\end{array}$ & $\begin{array}{l}\text { Design \& } \\
\text { Method }\end{array}$ & Participants & Theory & $\begin{array}{c}\text { Ethnicity } \\
\text { patient }\end{array}$ & $\begin{array}{l}\text { Setting, } \\
\text { country }\end{array}$ & Results & $\begin{array}{l}\text { Frame of } \\
\text { reference }\end{array}$ & $\mid \begin{array}{c}\text { Level of } \\
\text { contributi } \\
\text { on }^{1,2,-}\end{array}$ \\
\hline & & $\mathrm{n}$ & & & & & of the pt is a face saving strategy & & \\
\hline $\begin{array}{l}\text { Roberts } \\
\text { et al., } \\
2005\end{array}$ & English & $\begin{array}{l}\text { Qualitativ } \\
\text { e, video } \\
\text { observatio } \\
\text { n }\end{array}$ & 232 video's & None & Mixed & GP, UK & $\begin{array}{l}\text { Misunderstanding because of: pronunciation, word } \\
\text { stress, intonation, speech delivery, grammar, } \\
\text { vocabulary, lack of contextual information, style of } \\
\text { presentation. Communication style is a more } \\
\text { important factor than culturally specific health } \\
\text { beliefs }\end{array}$ & Observer & High $(+/+)$ \\
\hline $\begin{array}{l}\text { Cheng et } \\
\text { al., } 2004\end{array}$ & English & \begin{tabular}{|l} 
Quantitati \\
ve, \\
questionna \\
ire
\end{tabular} & |1040 Patients & None & $\begin{array}{l}\text { Aboriginal } \\
\text { vs non- } \\
\text { Aboriginal }\end{array}$ & \begin{tabular}{|l} 
Anesthesi \\
ology, \\
Australia
\end{tabular} & \begin{tabular}{|l} 
Communication difficulty in minority pts was \\
pervasive and often unrecognized. Language was a \\
barrier. Minority pts understood less
\end{tabular} & Patient & High $(+/+)$ \\
\hline $\begin{array}{l}\text { Sleath et } \\
\text { al., } 2004\end{array}$ & English & $\begin{array}{l}\text { Quantitati } \\
\text { ve, } \\
\text { interview } \\
\end{array}$ & $\begin{array}{l}141 \text { Patients, } \\
80 \text { doctors }\end{array}$ & None & \begin{tabular}{|l} 
Hispanic \\
vs non- \\
Hispanic \\
\end{tabular} & $\begin{array}{l}\text { Depressio } \\
\text { n care, } \\
\text { US }\end{array}$ & $\begin{array}{l}\text { Hispanic ethnicity of pts and language were not } \\
\text { significant related to dr-pt communication about } \\
\text { how to overcome depression }\end{array}$ & Patient & $\mid \begin{array}{l}\text { Medium } \\
(-/+)\end{array}$ \\
\hline $\begin{array}{l}\text { Katz et } \\
\text { al., } 2004\end{array}$ & English & \begin{tabular}{|l} 
Mixed, \\
focus \\
group + su \\
rvey
\end{tabular} & \begin{tabular}{|l}
45 Patients \\
for focus \\
groups, 397 \\
patients for \\
survey
\end{tabular} & None & African & $\begin{array}{l}\text { Oncology } \\
\text {, US }\end{array}$ & $\begin{array}{l}\text { Pt-dr communication was a discussion theme. } 75 \% \\
\text { of pts were considered having good communication. } \\
\text { Those were more likely to be screened for cancer }\end{array}$ & Patient & $\mid \begin{array}{l}\text { Medium } \\
(+/-)\end{array}$ \\
\hline $\begin{array}{l}\text { Johnson } \\
\text { et al., } \\
2004\end{array}$ & English & \begin{tabular}{|l} 
Quantitati \\
ve, \\
audiotapes \\
+ survey
\end{tabular} & $\begin{array}{l}458 \text { Patients, } \\
61 \text { doctors }\end{array}$ & None & $\begin{array}{l}\text { African } \\
\text { American } \\
\text { vs White }\end{array}$ & US & $\begin{array}{l}\text { Drs were more verbally dominant, less pt-centered } \\
\text { and use a less positive affective tone with AA pts }\end{array}$ & Observer & $\mid \operatorname{High}(+/+)$ \\
\hline Mosen et & English & Quantitati & 570 Patients & None & Spanish & Pediatrics & Spanish speaking pts reported worse experiences & Patient & High $(+/+)$ \\
\hline
\end{tabular}

This is a NIVEL certified Post Print, more info at http://www.nivel.eu 
Paternotte, E., Dulmen, S. van, Lee, N. van der, Scherpbier, A.J.J.A., Scheele, F. Factors influencing intercultural doctor-patient communication: a realist

\begin{tabular}{|c|c|c|c|c|c|c|c|c|c|}
\hline $\begin{array}{c}\text { Author } \\
\text { year }\end{array}$ & $\begin{array}{c}\text { Languag } \\
\text { e }\end{array}$ & $\begin{array}{c}\text { Design \& } \\
\text { Method }\end{array}$ & Participants & Theory & $\begin{array}{c}\text { Ethnicity } \\
\text { patient }\end{array}$ & $\begin{array}{l}\text { Setting, } \\
\text { country }\end{array}$ & Results & $\begin{array}{l}\text { Frame of } \\
\text { reference }\end{array}$ & $\begin{array}{c}\text { Level of } \\
\text { contributi } \\
\text { on }^{1,2,-*}\end{array}$ \\
\hline al., 2004 & & ve, survey & & & speaking & US & $\begin{array}{l}\text { with dr communication, because of bad explanation } \\
\text { and less time }\end{array}$ & & \\
\hline $\begin{array}{l}\text { Weitzma } \\
\text { n et al., } \\
2004\end{array}$ & English & $\mid \begin{array}{l}\text { Qualitativ } \\
\text { e, focus } \\
\text { groups }\end{array}$ & 25 Patients & None & Latino & US & \begin{tabular}{|l|} 
Barriers in communication are lack of \\
trustworthiness, experiences with healthcare and \\
language. Language skills of the dr are more \\
important than ethnicity. Pts stated that assertiveness \\
was not an option. The combination of language \\
barrier and being not assertive is difficult \\
\end{tabular} & Patient & $\operatorname{High}(+/+)$ \\
\hline $\begin{array}{l}\text { Fernande } \\
\text { z et al., } \\
2004\end{array}$ & English & $\begin{array}{l}\text { Quantitati } \\
\text { ve, } \\
\text { questionna } \\
\text { ire }\end{array}$ & $\begin{array}{l}116 \text { Patients, } \\
48 \text { doctors }\end{array}$ & None & $\begin{array}{l}\text { Spanish } \\
\text { speaking }\end{array}$ & $\begin{array}{l}\text { Primary } \\
\text { care, US }\end{array}$ & $\begin{array}{l}\text { Pts were more likely to report better interpersonal } \\
\text { processes of care when their dr had a higher self- } \\
\text { rated language ability and cultural competence }\end{array}$ & $\begin{array}{l}\text { Patient }+ \text { doct } \\
\text { or }\end{array}$ & $\operatorname{High}(+/+)$ \\
\hline \begin{tabular}{|l|} 
Johnson \\
et al., \\
2004 \\
\end{tabular} & English & \begin{tabular}{|l|} 
Quantitati \\
ve, \\
interview \\
\end{tabular} & ||6299 Patients & None & Mixed & US & $\begin{array}{l}\text { Hispanic and Asian pts were less likely than White } \\
\text { and AA pts to say that the dr listened well; they } \\
\text { understood everything, shared DM, had enough time }\end{array}$ & Patient & $\mid \begin{array}{l}\text { Medium } \\
(+/-)\end{array}$ \\
\hline $\begin{array}{l}\text { Barkin et } \\
\text { al., } 2003\end{array}$ & English & \begin{tabular}{|l} 
Quantitati \\
ve, \\
questionna \\
ire, pre- \\
test
\end{tabular} & \begin{tabular}{|l}
15 Patients, 5 \\
doctors
\end{tabular} & None & Latino & $\begin{array}{l}\text { Pediatrics } \\
\text {, US }\end{array}$ & Baseline trust and communication were high & Patient & Low $(-/-)$ \\
\hline $\begin{array}{l}\text { Cooper } \\
\text { et al., } \\
2003\end{array}$ & English & \begin{tabular}{|l|} 
Quantitati \\
ve, \\
audiotapes \\
+ questio \\
\end{tabular} & \begin{tabular}{||}
252 Patients, \\
31 doctors
\end{tabular} & None & 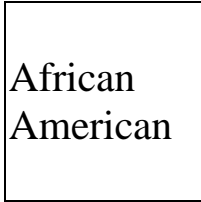 & US & \begin{tabular}{|l} 
Race discordant visits were shorter and had a less pt \\
positive effect. There were no differences in DM \\
and satisfaction \\
AA pts were sensitive to interpersonal cues from the
\end{tabular} & $\begin{array}{l}\text { Patient + obs } \\
\text { erver }\end{array}$ & $\begin{array}{l}\text { Medium } \\
(-/+)\end{array}$ \\
\hline
\end{tabular}

This is a NIVEL certified Post Print, more info at http://www.nivel.eu 
Paternotte, E., Dulmen, S. van, Lee, N. van der, Scherpbier, A.J.J.A., Scheele, F. Factors influencing intercultural doctor-patient communication: a realist

\begin{tabular}{|c|c|c|c|c|c|c|c|c|c|}
\hline $\begin{array}{c}\text { Author } \\
\text { year }\end{array}$ & $\begin{array}{c}\text { Languag } \\
\text { e }\end{array}$ & $\begin{array}{l}\text { Design \& } \\
\text { Method }\end{array}$ & Participants & Theory & $\begin{array}{c}\text { Ethnicity } \\
\text { patient }\end{array}$ & $\begin{array}{l}\text { Setting, } \\
\text { country }\end{array}$ & Results & $\begin{array}{l}\text { Frame of } \\
\text { reference }\end{array}$ & $\mid \begin{array}{c}\text { Level of } \\
\text { contributi } \\
\text { on }^{1,2, *}\end{array}$ \\
\hline & & nnaire & & & & & $\begin{array}{l}\text { dr, because of historical and personal experiences } \\
\text { with discrimination }\end{array}$ & & \\
\hline $\begin{array}{l}\text { Harmsen } \\
\text { et al., } \\
2003\end{array}$ & English & \begin{tabular}{|l} 
Quantitati \\
ve, \\
questionna \\
ire + inter \\
views \\
\end{tabular} & \begin{tabular}{|l}
87 Patients, \\
87 doctors
\end{tabular} & $\begin{array}{l}\text { Kleinman } \\
\text { et al. } 1978\end{array}$ & Mixed & $\begin{array}{l}\text { GP, the } \\
\text { Netherlan } \\
\text { ds }\end{array}$ & \begin{tabular}{|l} 
Communication of dr with minority pts was less \\
effective, than with pt of ethnic majority. There was \\
more misunderstanding, more non-compliance and \\
less mutual understanding, especially in the minority \\
group with mixed traditional and western cultures
\end{tabular} & $\begin{array}{l}\text { Patient }+ \text { doct } \\
\text { or }\end{array}$ & High $(+/+)$ \\
\hline $\begin{array}{l}\text { Saha et } \\
\text { al., } 2003\end{array}$ & English & $\begin{array}{l}\text { Quantitati } \\
\text { ve, } \\
\text { questionna } \\
\text { ire }\end{array}$ & ||6299 Patients & None & Mixed & US & $\begin{array}{l}\text { Ratings of dr behavior, cultural sensitivity and dr-pt } \\
\text { interactions were lower among Hispanic and Asian } \\
\text { pts, than Black and White pts. Non-White pts were } \\
\text { less satisfied with healthcare }\end{array}$ & Patients & $\mid \begin{array}{l}\text { Medium } \\
(-/+)\end{array}$ \\
\hline $\begin{array}{l}\text { Piette et } \\
\text { al., } 2003\end{array}$ & English & $\begin{array}{l}\text { Quantitati } \\
\text { ve, } \\
\text { questionna } \\
\text { ire }\end{array}$ & 752 Patients & None & Mixed & $\begin{array}{l}\text { Diabetes, } \\
\text { US }\end{array}$ & $\begin{array}{l}\text { AA and Hispanic pts reported better general } \\
\text { communication. AA pts and other minorities } \\
\text { reported better specific communication than White } \\
\text { and Hispanic pts }\end{array}$ & Patient & $\mid \begin{array}{l}\text { Medium } \\
(+/-)\end{array}$ \\
\hline $\begin{array}{l}\text { Shapiro } \\
\text { et al., } \\
2003\end{array}$ & English & \begin{tabular}{|l} 
Quantitati \\
ve, \\
questionna \\
ire
\end{tabular} & |107 Doctors & None & Mixed & \begin{tabular}{|l} 
Family \\
and \\
internal \\
medicine, \\
US
\end{tabular} & $\begin{array}{l}\text { Drs tented to identify serious cross-cultural } \\
\text { problems as those that focused on perceived pt } \\
\text { shortcoming. Family medicine drs rated culturally } \\
\text { competent communication as more relevant than } \\
\text { internal medicine drs. Drs found themselves } \\
\text { competent in intercultural communication } \\
\end{array}$ & Doctor & $\mid \operatorname{High}(+/+)$ \\
\hline $\begin{array}{l}\text { Lingard } \\
\text { et al., } \\
2002\end{array}$ & English & $\begin{array}{l}\text { Qualitativ } \\
\text { e, focus } \\
\text { groups }\end{array}$ & 29 Doctors & None & Mixed & |Pediatrics & $\begin{array}{l}\text { Drs believed that lack of experiences and knowledge } \\
\text { about other cultures caused their communication } \\
\text { difficulties. Drs taught that prejudice was not an }\end{array}$ & Doctor & High $(+/+)$ \\
\hline
\end{tabular}


Paternotte, E., Dulmen, S. van, Lee, N. van der, Scherpbier, A.J.J.A., Scheele, F. Factors influencing intercultural doctor-patient communication: a realist

\begin{tabular}{|c|c|c|c|c|c|c|c|c|c|}
\hline $\begin{array}{c}\text { Author } \\
\text { year }\end{array}$ & $\begin{array}{c}\text { Languag } \\
\text { e }\end{array}$ & $\begin{array}{c}\text { Design \& } \\
\text { Method }\end{array}$ & Participants & Theory & $\begin{array}{c}\text { Ethnicity } \\
\text { patient }\end{array}$ & $\begin{array}{l}\text { Setting, } \\
\text { country }\end{array}$ & Results & $\begin{array}{l}\text { Frame of } \\
\text { reference }\end{array}$ & $\begin{array}{c}\text { Level of } \\
\text { contributi } \\
\text { on }^{1,2, *}\end{array}$ \\
\hline & & & & & & & $\begin{array}{l}\text { issue. Drs had difficulties with using the right } \\
\text { interview technique }\end{array}$ & & \\
\hline $\begin{array}{l}\text { Sleath et } \\
\text { al., } 2003\end{array}$ & English & \begin{tabular}{|l} 
Qualitativ \\
e, \\
audiotapes \\
+ docume \\
nt \\
analyses
\end{tabular} & $\begin{array}{l}98 \text { Patients, } \\
25 \text { doctors }\end{array}$ & None & Hispanic & $\begin{array}{l}\text { Family } \\
\text { and } \\
\text { general } \\
\text { medicine, } \\
\text { US }\end{array}$ & $\begin{array}{l}\text { Non-Hispanic pts were more likely to give } \\
\text { information about their antidepressants than } \\
\text { Hispanic pts }\end{array}$ & Observer & Low $(-/-)$ \\
\hline $\begin{array}{l}\text { Bubano } \\
\text { et al., } \\
2003\end{array}$ & English & \begin{tabular}{|l|} 
Quantitati \\
ve, \\
questionna \\
ire
\end{tabular} & 62 Doctors & None & $\begin{array}{l}\text { Spanish } \\
\text { speaking }\end{array}$ & $\begin{array}{l}\text { Pediatrics } \\
\text {, US }\end{array}$ & $\begin{array}{l}\text { Drs experienced limitations in their language. Some } \\
\text { drs avoid communication with pts with limited } \\
\text { English proficiency }\end{array}$ & Doctor & $\mid \begin{array}{l}\text { Medium } \\
(+/-)\end{array}$ \\
\hline $\begin{array}{l}\text { Browner } \\
\text { et al., } \\
2003\end{array}$ & English & \begin{tabular}{|l|} 
Qualitativ \\
e, \\
interview \\
\end{tabular} & 156 Patients & None & Mexican & $\begin{array}{l}\text { Prenatal } \\
\text { care, US }\end{array}$ & $\begin{array}{l}\text { Miscommunication due to medical jargon, problems } \\
\text { of translation, problems of trust }\end{array}$ & Patient & $\mid \begin{array}{l}\text { Medium } \\
(-/+)\end{array}$ \\
\hline $\begin{array}{l}\text { Sleath et } \\
\text { al., } 2002\end{array}$ & English & \begin{tabular}{|l} 
Quantitati \\
ve, \\
audiotapes \\
+ interview \\
pt + questi \\
onnaire dr
\end{tabular} & $\begin{array}{l}383 \text { Patients, } \\
27 \text { doctors }\end{array}$ & None & $\begin{array}{l}\text { Hispanic } \\
\text { vs non- } \\
\text { Hispanic }\end{array}$ & $\begin{array}{l}\text { Primary } \\
\text { care, US }\end{array}$ & \begin{tabular}{|l} 
Drs asked Hispanic pts more open-ended questions. \\
Pts' ethnicity and language did not influence any \\
other aspect of dr-pt communication about \\
depression or anxiety
\end{tabular} & $\begin{array}{l}\text { Observer }+\mathrm{p} \\
\text { atient }+ \text { docto } \\
\mathrm{r}\end{array}$ & $\begin{array}{l}\text { Medium } \\
(-/+)\end{array}$ \\
\hline $\begin{array}{l}\text { Kelly et } \\
\text { al., } 2002\end{array}$ & English & Qualitativ & 10 Doctors & None & $\begin{array}{l}\text { Original } \\
\text { inhabitants }\end{array}$ & $\begin{array}{l}\text { Family } \\
\text { medicine, }\end{array}$ & $\begin{array}{l}\text { During pt-dr communication, drs talked less, took } \\
\text { more time and were comfortable with silence. Pts' } \\
\text { illnesses are not distinct from their community }\end{array}$ & Doctor & High $(+/+)$ \\
\hline
\end{tabular}


Paternotte, E., Dulmen, S. van, Lee, N. van der, Scherpbier, A.J.J.A., Scheele, F. Factors influencing intercultural doctor-patient communication: a realist

\begin{tabular}{|c|c|c|c|c|c|c|c|c|c|}
\hline $\begin{array}{c}\text { Author } \\
\text { year }\end{array}$ & $\begin{array}{c}\text { Languag } \\
\mathbf{e}\end{array}$ & $\mid \begin{array}{c}\text { Design \& } \\
\text { Method }\end{array}$ & Participants & Theory & $\begin{array}{c}\text { Ethnicity } \\
\text { patient }\end{array}$ & $\begin{array}{l}\text { Setting, } \\
\text { country }\end{array}$ & Results & $\begin{array}{l}\text { Frame of } \\
\text { reference }\end{array}$ & $\mid \begin{array}{c}\text { Level of } \\
\text { contributi } \\
\text { on }^{1,2,-}\end{array}$ \\
\hline & & interview & & & Canada & Canada & $\begin{array}{l}\text { Context: relations, culture and values are } \\
\text { inseparable. Drs behavior and understanding } \\
\text { changed when dealing with ethnic different pts. Pts } \\
\text { used an unfamiliar mode of verbal communication, } \\
\text { for example story telling }\end{array}$ & & \\
\hline $\begin{array}{l}\text { Van } \\
\text { Wieringe } \\
\text { n et al., } \\
2002\end{array}$ & English & $\begin{array}{l}\text { Mixed, } \\
\text { video } \\
\text { observatio } \\
\text { n + intervi } \\
\text { ew + quest } \\
\text { ionnaire }\end{array}$ & \begin{tabular}{|l}
88 Parents, 8 \\
doctors
\end{tabular} & $\begin{array}{l}\text { Kleinman } \\
1980\end{array}$ & Mixed & $\begin{array}{l}\text { Primary } \\
\text { care, The } \\
\text { Netherlan } \\
\text { ds }\end{array}$ & $\begin{array}{l}\text { Ethnic minority pts more often reported problems in } \\
\text { their relationship with the dr, they had different } \\
\text { beliefs about health and they were less satisfied with } \\
\text { the communication. Good relationship is necessary } \\
\text { for mutual understanding }\end{array}$ & $\begin{array}{l}\text { Patient }+ \text { doct } \\
\text { or }+ \text { observer }\end{array}$ & $\mid \operatorname{High}(+/+)$ \\
\hline $\begin{array}{l}\text { Stevens } \\
\text { et al., } \\
2002\end{array}$ & English & $\begin{array}{l}\text { Mixed, } \\
\text { interview }\end{array}$ & 413 Parents & None & Mixed & $\begin{array}{l}\text { Pediatrics } \\
\text {, US }\end{array}$ & $\begin{array}{l}\text { Ethnic minority pts experienced poorer pt-dr } \\
\text { compared with White pts. Especially in restriction of } \\
\text { freedom in choosing were to seek care }\end{array}$ & Patient & Low $(-/-)$ \\
\hline $\begin{array}{l}\text { Collins } \\
\text { et al., } \\
2002\end{array}$ & English & $\mid \begin{array}{l}\text { Qualitativ } \\
\text { e, focus } \\
\text { group }\end{array}$ & 13 Patients & None & $\begin{array}{l}\text { White vs } \\
\text { black }\end{array}$ & $\begin{array}{l}\text { Cardiolog } \\
\text { y, US }\end{array}$ & \begin{tabular}{|l|} 
Four domains of communication on pt's preferences \\
and comfort. 1 . Substance of information 2. \\
Recommendations are inconsistent with \\
expectations 3. dr argumentation for extra tests \\
failed 4. importance of trusting their dr. Lack of \\
substance and vagueness of information may be \\
linked to feelings of mistrust towards dr
\end{tabular} & Patient & High $(+/+)$ \\
\hline $\begin{array}{l}\text { Sleath et } \\
\text { al., } 2001\end{array}$ & English & $\left|\begin{array}{l}\text { Quantitati } \\
\text { ve, } \\
\text { audiotapes } \\
\text { + questio }\end{array}\right|$ & $\begin{array}{l}250 \text { Patients, } \\
27 \text { doctors }\end{array}$ & None & $\begin{array}{l}\text { Hispanic } \\
\text { vs non- } \\
\text { Hispanic }\end{array}$ & $\begin{array}{l}\text { General } \\
\text { medicine, } \\
\text { US }\end{array}$ & \begin{tabular}{|l} 
There were no ethnic differences in dr-pt \\
communication about alternative therapies. Drs with \\
less experience were more likely to ask pts more \\
questions. Less pts preferred their visit to be in their
\end{tabular} & $\begin{array}{l}\text { Observer }+p \\
\text { atient }+ \text { docto } \\
\mathrm{r}\end{array}$ & High $(+/+)$ \\
\hline
\end{tabular}

This is a NIVEL certified Post Print, more info at http://www.nivel.eu 
Paternotte, E., Dulmen, S. van, Lee, N. van der, Scherpbier, A.J.J.A., Scheele, F. Factors influencing intercultural doctor-patient communication: a realist

\begin{tabular}{|c|c|c|c|c|c|c|c|c|c|}
\hline $\begin{array}{c}\text { Author } \\
\text { year }\end{array}$ & $\begin{array}{c}\text { Languag } \\
\text { e }\end{array}$ & $\begin{array}{c}\text { Design \& } \\
\text { Method }\end{array}$ & Participants & Theory & $\begin{array}{c}\text { Ethnicity } \\
\text { patient }\end{array}$ & $\begin{array}{l}\text { Setting, } \\
\text { country }\end{array}$ & Results & $\begin{array}{l}\text { Frame of } \\
\text { reference }\end{array}$ & $\mid \begin{array}{c}\text { Level of } \\
\text { contributi } \\
\text { on }^{1,2, *}\end{array}$ \\
\hline & & $\begin{array}{l}\text { nnaire }+ \text { in } \\
\text { terview }\end{array}$ & & & & & primary language & & \\
\hline $\begin{array}{l}\text { Rivadene } \\
\text { yra et al., } \\
2000\end{array}$ & English & \begin{tabular}{|l} 
Quantitati \\
ve, video \\
observatio \\
n
\end{tabular} & \begin{tabular}{|l}
38 Patients, \\
19 doctors
\end{tabular} & None & $\begin{array}{l}\text { English vs } \\
\text { Spanish } \\
\text { speaking }\end{array}$ & $\begin{array}{l}\text { Primary } \\
\text { care, US }\end{array}$ & $\begin{array}{l}\text { Spanish speaking pts made fewer comments and } \\
\text { were more ignored. Language rather than dissimilar } \\
\text { ethnic backgrounds precipitated the differences in } \\
\text { offers made by pts and facilitations provided by drs }\end{array}$ & Observer & $\begin{array}{l}\text { Medium }(- \\
/+)\end{array}$ \\
\hline $\begin{array}{l}\text { Sleath et } \\
\text { al., } 2000\end{array}$ & English & $\begin{array}{l}\text { Quantitati } \\
\text { ve, } \\
\text { audiotapes } \\
\text { analyses }\end{array}$ & $\begin{array}{l}427 \text { Patients, } \\
27 \text { doctors }\end{array}$ & None & $\begin{array}{l}\text { Hispanic } \\
\text { vs non- } \\
\text { Hispanic }\end{array}$ & \begin{tabular}{|l|} 
Family \\
and \\
general \\
medicine, \\
US
\end{tabular} & $\begin{array}{l}\text { Drs were equally likely to express empathy to } \\
\text { Hispanic and non-Hispanic pts. Drs were more } \\
\text { likely to express positivism to non-Hispanic than to } \\
\text { Hispanic pts }\end{array}$ & Observer & High $(+/+)$ \\
\hline $\begin{array}{l}\text { Cooper- } \\
\text { Patrick } \\
\text { et al., } \\
1999\end{array}$ & English & $\begin{array}{l}\text { Quantitati } \\
\text { ve, } \\
\text { telephone } \\
\text { interview }\end{array}$ & $\begin{array}{l}1861 \text { Patients, } \\
64 \text { doctors }\end{array}$ & None & Mixed & $\begin{array}{l}\text { Primary } \\
\text { care, US }\end{array}$ & $\begin{array}{l}\text { Ethnic minority pts rated their visits with dr as less } \\
\text { participatory than White pts }\end{array}$ & Patient & $\mid \begin{array}{l}\text { Medium } \\
(-/+)\end{array}$ \\
\hline $\begin{array}{l}\text { Morales } \\
\text { et al., } \\
1999\end{array}$ & English & $\begin{array}{l}\text { Quantitati } \\
\text { ve, } \\
\text { questionna } \\
\text { ire }\end{array}$ & 7093 Patients & None & Mixed & US & $\begin{array}{l}\text { Latino/Spanish pts were more dissatisfied with } \mathrm{dr} \\
\text { communication (listening, answers to the questions, } \\
\text { explanations, support) than Latino/English pts }\end{array}$ & Patient & High $(+/+)$ \\
\hline $\begin{array}{l}\text { David et } \\
\text { al., } 1998\end{array}$ & English & \begin{tabular}{|l} 
Quantitati \\
ve, \\
questionna \\
ire
\end{tabular} & 261 Patients & None & Mixed & $\begin{array}{l}\text { Primary } \\
\text { care, US }\end{array}$ & $\begin{array}{l}\text { Ethnic minority pts experienced less explanation } \\
\text { about side effects of medication, were less satisfied } \\
\text { with care than pts of ethnic majority. Both groups } \\
\text { experienced that the dr understands them and feel } \\
\text { that they have enough time to communicate with the } \\
\end{array}$ & Patient & High $(+/+)$ \\
\hline
\end{tabular}


Paternotte, E., Dulmen, S. van, Lee, N. van der, Scherpbier, A.J.J.A., Scheele, F. Factors influencing intercultural doctor-patient communication: a realist

\begin{tabular}{|c|c|c|c|c|c|c|c|c|c|}
\hline $\begin{array}{c}\text { Author } \\
\text { year }\end{array}$ & $\begin{array}{c}\text { Languag } \\
\mathbf{e}\end{array}$ & $\begin{array}{c}\text { Design \& } \\
\text { Method }\end{array}$ & Participants & Theory & $\begin{array}{c}\text { Ethnicity } \\
\text { patient }\end{array}$ & $\begin{array}{l}\text { Setting, } \\
\text { country }\end{array}$ & Results & $\begin{array}{l}\text { Frame of } \\
\text { reference }\end{array}$ & $\mid \begin{array}{c}\text { Level of } \\
\text { contributi } \\
\text { on }^{1,2, *}\end{array}$ \\
\hline & & & & & & & $\begin{array}{l}\text { dr. A language barrier impacts negatively on pt } \\
\text { satisfaction }\end{array}$ & & \\
\hline $\begin{array}{l}\text { Rodrigue } \\
\text { z et al., } \\
1998\end{array}$ & English & $\begin{array}{l}\text { Qualitativ } \\
\text { e, focus } \\
\text { group }\end{array}$ & 28 Patients & None & $\begin{array}{l}\text { Latina and } \\
\text { Asian }\end{array}$ & US & \begin{tabular}{|l|} 
Pts identified elements to improve the dr-pt \\
communication in the behavior of the dr: trust, \\
compassion, and understanding. Pts wanted the dr to \\
initiate discussion about abuse. Pts expressed their \\
perspectives in culturally distinctive way
\end{tabular} & Patient & High $(+/+)$ \\
\hline $\begin{array}{l}\text { Dyregro } \\
\text { v et al., } \\
1997\end{array}$ & $\begin{array}{l}\text { Norwegi } \\
\text { an }\end{array}$ & $\begin{array}{l}\text { Qualitativ } \\
\text { e, } \\
\text { interviews }\end{array}$ & $\mid \begin{array}{l}15 \text { doctors, } 10 \\
\text { patients }\end{array}$ & $\begin{array}{l}\text { Socio- } \\
\text { cultural } \\
\text { theory }\end{array}$ & Mixed & $\begin{array}{l}\text { GP, } \\
\text { Norway }\end{array}$ & \begin{tabular}{|l} 
Drs found it frustrating communicating with \\
immigrants, because of different thoughts and \\
norms, language and expectations, experience about \\
body and pain. Difficulties with discrepancy \\
between verbal and non-verbal communication, this \\
made it difficult to understand the immigrants \\
symptom description and their understanding of \\
illness
\end{tabular} & $\begin{array}{l}\text { Patient }+ \text { doct } \\
\text { or }\end{array}$ & High $(+/+)$ \\
\hline $\begin{array}{l}\text { Blöchlig } \\
\text { er et al., } \\
1997\end{array}$ & German & \begin{tabular}{|l} 
Mixed, \\
questionna \\
ire, focus \\
group
\end{tabular} & 314 Patients & None & Mixed & $\begin{array}{l}\text { GP, } \\
\text { Switzerla } \\
\text { nd }\end{array}$ & \begin{tabular}{|l|} 
Cultural and social factors complicated \\
communication during a dr-pt interaction and \\
caused that drs focused on a somatic diagnose. Most \\
drs felt that communication problems were related \\
to speaking a common language
\end{tabular} & Doctor & High $(+/+)$ \\
\hline $\begin{array}{l}\text { Cave et } \\
\text { al., } 1995\end{array}$ & English & $\begin{array}{l}\text { Qualitativ } \\
\text { e, focus } \\
\text { group }\end{array}$ & \begin{tabular}{|l}
13 Patients, 5 \\
doctors
\end{tabular} & None & Mixed & $\begin{array}{l}\text { Family } \\
\text { medicine, } \\
\text { US }\end{array}$ & \begin{tabular}{|l|} 
Drs thought that understanding pt' culture better \\
would achieve better diagnosis. Pts didn't \\
understand why the dr asked questions about their \\
culture. Pts found this intrusive. Barriers for the pt \\
are: little time, no explanation, expect that the dr \\
will know their culture; pts see Western medicine as \\
\end{tabular} & $\begin{array}{l}\text { Patient }+ \text { doct } \\
\text { or }\end{array}$ & High $(+/+)$ \\
\hline
\end{tabular}


Paternotte, E., Dulmen, S. van, Lee, N. van der, Scherpbier, A.J.J.A., Scheele, F. Factors influencing intercultural doctor-patient communication: a realist

\begin{tabular}{|c|c|c|c|c|c|c|c|c|c|}
\hline $\begin{array}{c}\text { Author } \\
\text { year }\end{array}$ & $\begin{array}{c}\text { Languag } \\
\text { e }\end{array}$ & $\begin{array}{l}\text { Design \& } \\
\text { Method }\end{array}$ & Participants & Theory & $\begin{array}{c}\text { Ethnicity } \\
\text { patient }\end{array}$ & $\begin{array}{l}\text { Setting, } \\
\text { country }\end{array}$ & Results & $\begin{array}{l}\text { Frame of } \\
\text { reference }\end{array}$ & $\begin{array}{c}\text { Level of } \\
\text { contributi } \\
\text { on }^{1,2, *}\end{array}$ \\
\hline & & & & & & & $\begin{array}{l}\text { superior. A facilitator for the pt is: trust in } \\
\text { knowledge of the dr. Barriers for drs: time pressure, } \\
\text { seeing pt not as an individual. Facilitators for the dr } \\
\text { are: awareness of culture, understanding the } \\
\text { isolation of minority pts, culturally sensitive } \\
\text { approach }\end{array}$ & & \\
\hline $\begin{array}{l}\text { Ari et al., } \\
1995\end{array}$ & English & $\begin{array}{l}\text { Qualitativ } \\
\text { e, } \\
\text { interview }\end{array}$ & |18 mothers & None & Japanese & GP's, UK & $\begin{array}{l}\text { Language was a barrier in face-to-face } \\
\text { communication. Pts found it difficult to understand } \\
\text { colloquial expressions. Drs were unfamiliar with } \\
\text { Japanese pt's expectations and experiences. } \\
\text { Facilitator for the pt is when the dr writes down the } \\
\text { keywords so they can use a dictionary at home }\end{array}$ & Patient & $\mid \begin{array}{l}\text { Medium } \\
(-/+)\end{array}$ \\
\hline $\begin{array}{l}\text { Favrat et } \\
\text { al., } 1994\end{array}$ & French & \begin{tabular}{|l} 
Quantitati \\
ve, \\
questionna \\
ire
\end{tabular} & \begin{tabular}{||}
612 Patients, \\
20 doctors
\end{tabular} & None & Mixed & $\begin{array}{l}\text { Outpatien } \\
\text { t clinic, } \\
\text { Switzerla } \\
\text { nd } \\
\end{array}$ & $\begin{array}{l}\text { Drs felt less satisfied with minority pts because of } \\
\text { communication difficulties, but they felt that they } \\
\text { have the same diagnostic accuracy as with other pts }\end{array}$ & Doctor & $\mid \begin{array}{l}\text { Medium } \\
(-/+)\end{array}$ \\
\hline $\begin{array}{l}\text { Krauss- } \\
\text { Mars et } \\
\text { al., } 1994\end{array}$ & English & \begin{tabular}{|l} 
Quantitati \\
ve, \\
questionna \\
ire
\end{tabular} & |40 Parents & None & Mixed & $\begin{array}{l}\text { Disabled } \\
\text { care, } \\
\text { South } \\
\text { Africa } \\
\end{array}$ & $\begin{array}{l}\text { Language differences tend to have a negative effect } \\
\text { on the communication. Black pts received less } \\
\text { explanation, less possibilities to ask questions, drs } \\
\text { didn't ask if the pt understood }\end{array}$ & Patient & $\mid \begin{array}{l}\text { Medium } \\
(-/+)\end{array}$ \\
\hline $\begin{array}{l}\text { Wilson } \\
\text { et al., } \\
1994\end{array}$ & English & \begin{tabular}{|l} 
Quantitati \\
ve, \\
questionna \\
ire
\end{tabular} & \begin{tabular}{|l}
813 Patients, \\
106 doctors
\end{tabular} & $\begin{array}{l}\text { Kleinman } \\
1977\end{array}$ & $\begin{array}{l}\text { Asian vs } \\
\text { White }\end{array}$ & $\begin{array}{l}\text { Psychiatr } \\
\text { y, UK }\end{array}$ & \begin{tabular}{|l} 
Asian and White pts registered the emotional \\
experiences equally, but they were communicated \\
and managed differently. Pts suggested differences \\
in the way which members of each group \\
understood the meaning of their distressed feelings
\end{tabular} & $\begin{array}{l}\text { Patient } \\
\text { +doctor }\end{array}$ & Low $(-/-)$ \\
\hline
\end{tabular}


Paternotte, E., Dulmen, S. van, Lee, N. van der, Scherpbier, A.J.J.A., Scheele, F. Factors influencing intercultural doctor-patient communication: a realist

\begin{tabular}{|c|c|c|c|c|c|c|c|c|c|}
\hline $\begin{array}{c}\text { Author } \\
\text { year }\end{array}$ & $\begin{array}{c}\text { Languag } \\
\text { e }\end{array}$ & $\begin{array}{c}\text { Design \& } \\
\text { Method }\end{array}$ & Participants & Theory & $\begin{array}{c}\text { Ethnicity } \\
\text { patient }\end{array}$ & $\begin{array}{l}\text { Setting, } \\
\text { country }\end{array}$ & Results & $\begin{array}{l}\text { Frame of } \\
\text { reference }\end{array}$ & $\mid \begin{array}{c}\text { Level of } \\
\text { contributi } \\
\text { on }^{1,2, *}\end{array}$ \\
\hline & & & & & & & in the context of a dr visit & & \\
\hline \begin{tabular}{|l|} 
Erzinger, \\
1991
\end{tabular} & English & $\mid \begin{array}{l}\text { Qualitativ } \\
\text { e, } \\
\text { interview } \\
+ \text { audiotap } \\
\text { es } \\
\text { analyses }\end{array}$ & $\left|\begin{array}{l}26 \text { Patients, } \\
11 \text { audiotapes, } \\
20 \text { doctors }\end{array}\right|$ & None & $\begin{array}{l}\text { Spanish } \\
\text { speaking }\end{array}$ & US & \begin{tabular}{|l} 
Facilitators for the pt: describe concerns, clarify \\
information conveyed by the dr, obtain an adequate \\
explanation, develop a personal relationship. \\
Facilitators for the dr: explore symptom, interpret \\
follow-up data, adequately explain and advise, \\
understand pt's personal situation. Success of the \\
medical encounter is determined by how dr and pt \\
each assist in completion of the others tasks. The dr \\
style of paraphrasing and using the pt's exact words \\
encourages the pt's elaboration of her concerns
\end{tabular} & $\begin{array}{l}\text { Observer }+\mathrm{p} \\
\text { atient }+ \text { docto } \\
\mathrm{r}\end{array}$ & High $(+/+)$ \\
\hline $\begin{array}{l}\text { Wright, } \\
1983\end{array}$ & English & \begin{tabular}{|l|} 
Mixed, \\
questionna \\
ire
\end{tabular} & |39 Doctors & None & $\begin{array}{l}\text { Asian vs } \\
\text { English }\end{array}$ & GP, UK & \begin{tabular}{|l} 
Drs felt that Asian pts consulted more often and \\
took up more time than English pts. Drs complained \\
about Asian pts complaining about trivial matters
\end{tabular} & Doctor & $\mid \begin{array}{l}\text { Medium } \\
(-/+)\end{array}$ \\
\hline $\begin{array}{l}\text { Hooper } \\
\text { et al., } \\
1982\end{array}$ & English & $\begin{array}{l}\text { Quantitati } \\
\text { ve, } \\
\text { observatio } \\
\text { n }\end{array}$ & $\mid \begin{array}{l}150 \\
\text { interactions } \\
\text { with } 15 \\
\text { doctors }\end{array}$ & None & Mixed & $\begin{array}{l}\text { Outpatien } \\
\text { t clinic, } \\
\text { US }\end{array}$ & \begin{tabular}{|l|} 
Dr's empathy behavior and time spending was \\
higher with Anglo-American pts, than with \\
Spanish-American pts. No differences in nonverbal \\
attention, courtesy and information giving. Cultural \\
differences without language differences influenced \\
the behavior of the dr
\end{tabular} & Observer & $\mid \begin{array}{l}\text { Medium } \\
(-/+)\end{array}$ \\
\hline $\begin{array}{l}\text { Shapiro } \\
\text { et al., } \\
1981\end{array}$ & English & \begin{tabular}{|l} 
Quantitati \\
ve, \\
audiotapes \\
analyses
\end{tabular} & \begin{tabular}{||l}
61 Patients, \\
10 doctors
\end{tabular} & None & $\begin{array}{l}\text { Hispanic } \\
\text { vs non- } \\
\text { Hispanic }\end{array}$ & US & $\begin{array}{l}\text { Drs performed better on dimensions of rapport, } \\
\text { explanation and ability to elicit pts feedback with } \\
\text { the non-Hispanic English speaking pt. There were } \\
\text { no differences in understanding the diagnosis }\end{array}$ & Observer & High $(+/+)$ \\
\hline Kline et & English & Quantitati & 40 Patients, & None & Mixed & Psychiatr & Latino pts were less satisfied with the help provided & Patient + doct & $\operatorname{High}(+/+)$ \\
\hline
\end{tabular}

This is a NIVEL certified Post Print, more info at http://www.nivel.eu 
Paternotte, E., Dulmen, S. van, Lee, N. van der, Scherpbier, A.J.J.A., Scheele, F. Factors influencing intercultural doctor-patient communication: a realist

\begin{tabular}{|c|c|c|c|c|c|c|c|c|c|}
\hline $\begin{array}{l}\text { Author } \\
\text { year }\end{array}$ & $\begin{array}{c}\text { Languag } \\
\text { e }\end{array}$ & $\begin{array}{c}\text { Design \& } \\
\text { Method }\end{array}$ & Participants & Theory & $\begin{array}{l}\text { Ethnicity } \\
\text { patient }\end{array}$ & $\begin{array}{l}\text { Setting, } \\
\text { country }\end{array}$ & Results & $\begin{array}{l}\text { Frame of } \\
\text { reference }\end{array}$ & $\begin{array}{c}\text { Level of } \\
\text { contributi } \\
\text { on }^{1,2, *}\end{array}$ \\
\hline al., 1980 & & \begin{tabular}{|l||} 
ve, \\
questionna \\
ire
\end{tabular} & 16 doctors & & & $\mathrm{y}, \mathrm{US}$ & $\begin{array}{l}\text { by the dr's specific advice. Drs thought that pts who } \\
\text { were interviewed directly in English felt more } \\
\text { appreciative, were more eager to return and felt } \\
\text { better understood. This was also more satisfactory } \\
\text { and comfortable to them }\end{array}$ & or & \\
\hline $\begin{array}{l}\text { Leng et } \\
\text { al., } 2012\end{array}$ & English & $\begin{array}{l}\text { Qualitativ } \\
\text { e, focus } \\
\text { group }\end{array}$ & 28 Patients & None & |Chinese & $\begin{array}{l}\text { Oncology } \\
\text {, US }\end{array}$ & $\begin{array}{l}\text { Pts expressed dissatisfaction with the amount, } \\
\text { reliability and comprehensibility of information. Pts } \\
\text { didn’t understand what their dr said. Language is a } \\
\text { barrier in participating in the treatment process }\end{array}$ & Patient & $\begin{array}{l}\text { Medium } \\
(-/+)\end{array}$ \\
\hline $\begin{array}{l}\text { Cox et } \\
\text { al., } 2012\end{array}$ & English & \begin{tabular}{|l||} 
Quantitati \\
ve, video \\
observatio \\
n
\end{tabular} & \begin{tabular}{|l}
405 \\
interactions \\
with 32 \\
doctors \\
\end{tabular} & None & Mixed & $\begin{array}{l}\text { Pediatrics } \\
\text {, US }\end{array}$ & $\begin{array}{l}\text { Drs communicated differently. Asian pts: fewer } \\
\text { relationship building utterances, Latino pts: less } \\
\text { information, AA: less engaged in DM }\end{array}$ & Observer & $\begin{array}{l}\text { Medium } \\
(-/+)\end{array}$ \\
\hline $\begin{array}{l}\text { Diamond } \\
\text { et al., } \\
2012\end{array}$ & English & \begin{tabular}{l||} 
Quantitati \\
ve, \\
questionna \\
ire
\end{tabular} & 68 Doctors & None & $\begin{array}{l}\text { Spanish } \\
\text { speaking }\end{array}$ & $\begin{array}{l}\text { General } \\
\text { medicine, } \\
\text { US }\end{array}$ & $\begin{array}{l}\text { With a language barrier drs used their own language } \\
\text { skills or an interpreter }\end{array}$ & Doctor & Low $(-/-)$ \\
\hline $\begin{array}{l}\text { Hoang et } \\
\text { al., } 2009\end{array}$ & English & \begin{tabular}{l||} 
Qualitativ \\
e, \\
interviews
\end{tabular} & 10 Patients & None & Asian & $\begin{array}{l}\text { Maternity } \\
\text { care, } \\
\text { Australia }\end{array}$ & $\begin{array}{l}\text { Pts faced language and cultural barriers which } \\
\text { affected the communication. They experience } \\
\text { confusion and conflicting expectations. Family was } \\
\text { very important for migrant pt. Drs and pts have } \\
\text { different habits }\end{array}$ & Patient & $\begin{array}{l}\text { Medium } \\
(-/+)\end{array}$ \\
\hline $\begin{array}{l}\text { Simon et } \\
\text { al., } 2005\end{array}$ & English & $\begin{array}{l}\text { Quantitati } \\
\text { ve, video }\end{array}$ & $\begin{array}{l}140 \\
\text { interactions }\end{array}$ & None & \begin{tabular}{|l} 
Caucasian \\
vs
\end{tabular} & $\begin{array}{l}\text { Paediatric } \\
\text { oncology, }\end{array}$ & $\begin{array}{l}\text { Caucasian pts were more successfully informed. No } \\
\text { differences in duration of consultation. Latino pts } \\
\text { were more openly emotional than White or AA pts }\end{array}$ & Observer & Low $(-/-)$ \\
\hline
\end{tabular}


Paternotte, E., Dulmen, S. van, Lee, N. van der, Scherpbier, A.J.J.A., Scheele, F. Factors influencing intercultural doctor-patient communication: a realist

\begin{tabular}{|c|c|c|c|c|c|c|c|c|c|}
\hline $\begin{array}{c}\text { Author } \\
\text { year }\end{array}$ & $\begin{array}{c}\text { Languag } \\
\text { e }\end{array}$ & $\begin{array}{c}\text { Design \& } \\
\text { Method }\end{array}$ & Participants & Theory & $\begin{array}{c}\text { Ethnicity } \\
\text { patient }\end{array}$ & $\begin{array}{l}\text { Setting, } \\
\text { country }\end{array}$ & Results & $\begin{array}{l}\text { Frame of } \\
\text { reference }\end{array}$ & $\begin{array}{c}\text { Level of } \\
\text { contributi } \\
\text { on }^{1,2, *}\end{array}$ \\
\hline & & \begin{tabular}{|l|} 
observatio \\
n
\end{tabular} & & & minorities & US & & & \\
\hline $\begin{array}{l}\text { Brugge } \\
\text { et al., } \\
2009\end{array}$ & English & $\begin{array}{l}\text { Qualitativ } \\
\text { e, focus } \\
\text { group }\end{array}$ & ||85 adults & None & Mixed & $\begin{array}{l}\text { Pediatrics } \\
\text {, US }\end{array}$ & \begin{tabular}{|l} 
Pt didn't separate issues of understanding from their \\
overall narratives of experiences with healthcare and \\
illness. Language discordant communication was an \\
issue for low educated Cantonese pts. Pts preferred a \\
doctor of their own language
\end{tabular} & Patient & $\mid \begin{array}{l}\text { Medium } \\
(-/+)\end{array}$ \\
\hline $\begin{array}{l}\text { Chudley } \\
\text { et al., } \\
2007\end{array}$ & English & \begin{tabular}{|l} 
Quantitati \\
ve, \\
questionna \\
ire
\end{tabular} & 153 Doctors & None & Mixed & GP, UK & $\begin{array}{l}\text { Barriers in communication are: not feeling confident } \\
\text { with pts who speak a different language, not } \\
\text { knowing the ideas of the pt, feeling uncomfortable } \\
\text { with exploring sensitive topics. Facilitators: } \\
\text { awareness of their body language, understanding pt's } \\
\text { opinions, learning about pt's cultural perspective } \\
\end{array}$ & Doctor & $\mid \begin{array}{l}\text { Medium } \\
(-/+)\end{array}$ \\
\hline $\begin{array}{l}\text { Degan et } \\
\text { al., } 2003\end{array}$ & Italian & $\begin{array}{l}\text { Mixed, } \\
\text { document } \\
\text { analyses, } \\
\text { questionna } \\
\text { ire }\end{array}$ & 8 Doctors & None & Mixed & $\begin{array}{l}\text { Gynecolo } \\
\text { gy, Italy, }\end{array}$ & $\begin{array}{l}\text { The difficulties reported by drs concerned "give } \\
\text { clinical information”, "collect medical history" and } \\
\text { "assess the symptoms”. Critical moments related to } \\
\text { their own competence concerned "gather } \\
\text { information and symptoms” and "give therapeutic } \\
\text { information”. Compared to the knowledge of a } \\
\text { foreign language } 20.8 \% \text { said that they do not know } \\
\text { any foreign language, while others claim to know } \\
\text { European languages }\end{array}$ & Doctor & $\mid \begin{array}{l}\text { Medium } \\
(+/-)\end{array}$ \\
\hline $\begin{array}{l}\text { Gerlach } \\
\text { et al., } \\
2008\end{array}$ & German & $\begin{array}{l}\text { Qualitativ } \\
\text { e, focus } \\
\text { group }\end{array}$ & |30 Doctors & None & Mixed & $\begin{array}{l}\text { GP, } \\
\text { Germany }\end{array}$ & $\begin{array}{l}\text { Verbal communication was a major problem. Drs } \\
\text { tried to have a non-discriminating attitude. Drs have } \\
\text { a profound effort for empathic understanding }\end{array}$ & Doctor & $\mid \begin{array}{l}\text { Medium } \\
(-/+)\end{array}$ \\
\hline
\end{tabular}


Paternotte, E., Dulmen, S. van, Lee, N. van der, Scherpbier, A.J.J.A., Scheele, F. Factors influencing intercultural doctor-patient communication: a realist

\begin{tabular}{|c|c|c|c|c|c|c|c|c|c|}
\hline $\begin{array}{c}\text { Author } \\
\text { year }\end{array}$ & $\begin{array}{c}\text { Languag } \\
\text { e }\end{array}$ & $\begin{array}{l}\text { Design \& } \\
\text { Method }\end{array}$ & Participants & Theory & $\begin{array}{c}\text { Ethnicity } \\
\text { patient }\end{array}$ & $\begin{array}{l}\text { Setting, } \\
\text { country }\end{array}$ & Results & $\begin{array}{l}\text { Frame of } \\
\text { reference }\end{array}$ & $\mid \begin{array}{c}\text { Level of } \\
\text { contributi } \\
\text { on }^{1,2,-}\end{array}$ \\
\hline $\begin{array}{l}\text { Gerlach } \\
\text { et al., } \\
2009\end{array}$ & German & $\begin{array}{l}\text { Qualitativ } \\
\text { e, focus } \\
\text { group }\end{array}$ & \begin{tabular}{||l}
33 Patients, \\
30 doctors
\end{tabular} & None & Black & 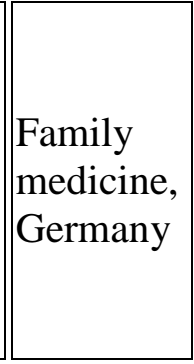 & $\begin{array}{l}\text { Barriers are: insufficient medical knowledge, } \\
\text { differences in respect to importance of language and } \\
\text { nonverbal communication, different illness models, } \\
\text { different experiences with discrimination. Pts named } \\
\text { the importance of medical competence of pts, } \\
\text { insufficient empathy of drs, insufficient time } \\
\text { management of the dr, insufficiency in valuing } \\
\text { diversity }\end{array}$ & $\begin{array}{l}\text { Patient }+ \text { doct } \\
\text { or }\end{array}$ & High $(+/+)$ \\
\hline $\begin{array}{l}\text { Gerlach } \\
\text { et al., } \\
2012\end{array}$ & German & $\begin{array}{l}\text { Qualitativ } \\
\text { e, focus } \\
\text { group }\end{array}$ & 39 Patients & None & Turkish & Germany & $\begin{array}{l}\text { Most pts experienced unequal care and } \\
\text { discrimination. Pts wanted to be seen as individuals, } \\
\text { expressed that empathy of the dr was often missing, } \\
\text { resulting in no trust }\end{array}$ & Patient & $\mid \begin{array}{l}\text { Medium } \\
(-/+)\end{array}$ \\
\hline $\begin{array}{l}\text { Neal et } \\
\text { al., } 2006\end{array}$ & English & \begin{tabular}{|l} 
Mixed, \\
video \\
observatio \\
n
\end{tabular} & $\begin{array}{l}83 \text { video's, } 11 \\
\text { doctors }\end{array}$ & None & South- & GP, UK & $\begin{array}{l}\text { White pts had more affective consultations and } \\
\text { played a more active role, as did the dr. Drs spent } \\
\text { less time in information giving and more time in } \\
\text { asking questions with SA pts. SA fluent English } \\
\text { speaking pts had the shortest consultations, SA non- } \\
\text { fluent English the longest }\end{array}$ & Observer & High $(+/+)$ \\
\hline $\begin{array}{l}\text { Ward et } \\
\text { al., } 2005\end{array}$ & English & \begin{tabular}{|l} 
Qualitativ \\
e, focus \\
group + in \\
terview
\end{tabular} & |18 Patients, & None & Mixed & $\begin{array}{l}\text { Home/co } \\
\text { mmunity } \\
\text { care, } \\
\text { Australia }\end{array}$ & $\begin{array}{l}\text { Pts experienced barriers in lack of information, } \\
\text { cultural factors, and negative experiences. Cultural } \\
\text { differences were a major barrier }\end{array}$ & $\begin{array}{l}\text { Patient }+ \text { doct } \\
\text { or }\end{array}$ & $\mid \begin{array}{l}\text { Medium } \\
(-/+)\end{array}$ \\
\hline $\begin{array}{l}\text { Zapka et } \\
\text { al., } 2006\end{array}$ & English & $\begin{array}{l}\text { Mixed, } \\
\text { interview }\end{array}$ & |90 Patients & \begin{tabular}{|l} 
Palmer, \\
Donabedia \\
n \& Povar
\end{tabular} & $\begin{array}{l}\text { Caucasian } \\
\text { vs African } \\
\text { American }\end{array}$ & $\mid \begin{array}{l}\text { Oncology } \\
\text {, US }\end{array}$ & \begin{tabular}{|l} 
Discussion about end-of-life topics was low. Dr-pt \\
communication occurred infrequently
\end{tabular} & Patient & Low $(-/-)$ \\
\hline
\end{tabular}




\begin{tabular}{|c|c|c|c|c|c|c|c|c|c|}
\hline $\begin{array}{c}\text { Author } \\
\text { year }\end{array}$ & $\begin{array}{c}\text { Languag } \\
\text { e }\end{array}$ & $\begin{array}{c}\text { Design \& } \\
\text { Method }\end{array}$ & Participants & Theory & $\begin{array}{c}\text { Ethnicity } \\
\text { patient }\end{array}$ & $\begin{array}{l}\text { Setting, } \\
\text { country }\end{array}$ & Results & $\begin{array}{l}\text { Frame of } \\
\text { reference }\end{array}$ & $\begin{array}{c}\text { Level of } \\
\text { contributi } \\
\text { on }^{1,2, *}=\end{array}$ \\
\hline & & & & 1991 & & & & & \\
\hline $\begin{array}{l}\text { Herselm } \\
\text { an et al., } \\
1996\end{array}$ & English & $\mid \begin{array}{l}\text { Qualitativ } \\
\text { e, } \\
\text { interview }\end{array}$ & 19 Patients & None & $\mid \begin{array}{l}\text { Xhosa } \\
\text { speaking }\end{array}$ & $\begin{array}{l}\text { South } \\
\text { Africa }\end{array}$ & $\begin{array}{l}\text { Dr felt the inability to speak the pt' language, which } \\
\text { could help them with better insights into the } \\
\text { perceptions of the pt. Pts lack adequate and } \\
\text { appropriate vocabulary. Pts tell the dr what they } \\
\text { believe the dr want to know. A barrier in the } \\
\text { communication is shortage of time. Success of the } \\
\text { process depends on the communication. Barriers } \\
\text { are: dr's lack of knowledge and understanding of the } \\
\text { pt, Defensiveness and unintelligible techniques that } \\
\text { pt use to provide information, unshared meanings } \\
\text { between drs and pts. There is an absence of fixed } \\
\text { patterning in the dr's communication strategies }\end{array}$ & Patient & $\begin{array}{l}\text { High } \\
(+/+)\end{array}$ \\
\hline $\mid \begin{array}{l}\text { Seijo et } \\
\text { al., } 1991\end{array}$ & English & \begin{tabular}{|l} 
Quantitati \\
ve, \\
observatio \\
n + intervi \\
ew
\end{tabular} & $\mid \begin{array}{l}51 \text { Patients, } \\
51 \text { doctors }\end{array}$ & None & Hispanic & $\begin{array}{l}\text { Internal } \\
\text { medicine, } \\
\text { US }\end{array}$ & $\begin{array}{l}\text { Language discordance between drs and pts can have } \\
\text { effect on interaction and its outcome by leading to } \\
\text { decreased pt information recall of the encounter and } \\
\text { decreased pt question asking behavior }\end{array}$ & Observer & $\begin{array}{l}\text { Medium } \\
(-/+)\end{array}$ \\
\hline
\end{tabular}

* Quality assessment on content ((1) rigor and (2) relevance), +is completely, - is partly.

${ }^{1}$ Rigor is whether the method used to generate that particular piece of data is credible and trustworthy.

${ }^{2}$ Relevance is whether the article contributes to answer our research question. 